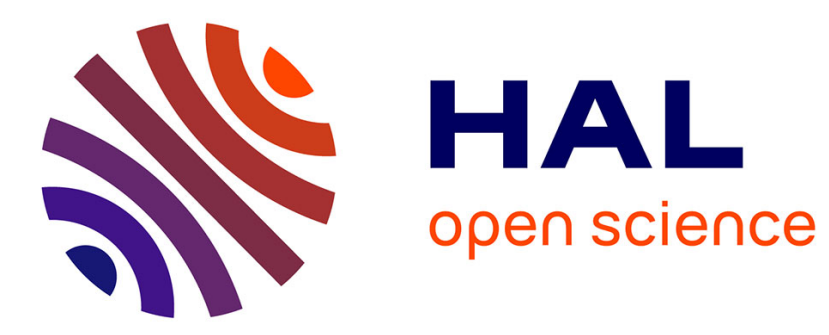

\title{
Characterization and Some Physicochemical Aspects of Pathological Microcalcifications
}

\author{
Dominique Bazin, Michel Daudon, Christèle Combes, Christian Rey
}

\section{To cite this version:}

Dominique Bazin, Michel Daudon, Christèle Combes, Christian Rey. Characterization and Some Physicochemical Aspects of Pathological Microcalcifications. Chemical Reviews, 2012, vol. 112, pp. 5092-5120. 10.1021/cr200068d . hal-01073611

\section{HAL Id: hal-01073611 \\ https://hal.science/hal-01073611}

Submitted on 10 Oct 2014

HAL is a multi-disciplinary open access archive for the deposit and dissemination of scientific research documents, whether they are published or not. The documents may come from teaching and research institutions in France or abroad, or from public or private research centers.
L'archive ouverte pluridisciplinaire HAL, est destinée au dépôt et à la diffusion de documents scientifiques de niveau recherche, publiés ou non, émanant des établissements d'enseignement et de recherche français ou étrangers, des laboratoires publics ou privés. 


\section{Open Archive TOULOUSE Archive Ouverte (OATAO)}

OATAO is an open access repository that collects the work of Toulouse researchers and makes it freely available over the web where possible.

This is an author-deposited version published in : http://oatao.univ-toulouse.fr/ Eprints ID : 12039

To link to this article : DOI: $10.1021 / \mathrm{cr} 200068 \mathrm{~d}$

URL : http://dx.doi.org/10.1021/cr200068d

\section{To cite this version :}

Bazin, Dominique and Daudon, Michel and Combes, Christèle and Rey, Christian Characterization and Some Physicochemical Aspects of Pathological Microcalcifications. (2012) Chemical Reviews, vol. $112\left(\mathrm{n}^{\circ} 10\right)$. pp. 5092-5120. ISSN 0009-2665

Any correspondance concerning this service should be sent to the repository administrator: staff-oatao@,listes-diff.inp-toulouse.fr 


\title{
Characterization and Some Physicochemical Aspects of Pathological Microcalcifications
}

\author{
D. Bazin, ${ }^{* \dagger \dagger}{ }^{\ddagger}$ M. Daudon, ${ }^{\S}$ C. Combes, $"$ and C. Rey ${ }^{\|}$
}

${ }^{\dagger}$ Laboratoire de Physique des Solides, CNRS, Université Paris-Sud, 91405 Orsay, France

${ }^{\ddagger}$ Laboratoire de Chimie de la Matière Condensée de Paris Université Pierre et Marie Curie et Collège de France, 11 place Marcelin Berthelot, 75231 Paris cedex 05, France

${ }^{\S}$ APHP, Hôpital Tenon, Service d'Explorations Fonctionnelles, 4 rue de la Chine, 75020 Paris, France

"Université de Toulouse, CIRIMAT, UPS-INPT-CNRS, ENSIACET, 4, allée Emile Monso, BP 44362, 31030 Toulouse Cedex 4, France

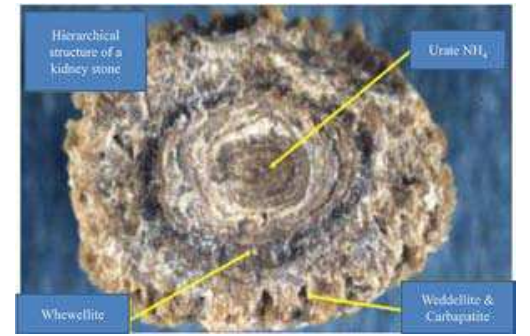

\section{CONTENTS}

1. Introduction

2. Medical Aspects Regarding Pathological Calcifications

2.1. Generalities on Pathological Calcifications

2.2. Origins

2.3. Concretion on Ectopic Calcification

3. Pathological Calcifications and Physicochemistry

3.1. Hierarchical Structure

3.2. Great Chemical Diversity

3.3. Solubility of Mineral Phases Involved in Pathological Calcifications

3.4. Nucleation and Crystal Growth

3.5. Important Markers of Biomineralization $\left(\mathrm{CO}_{3}{ }^{2-}\right.$ and $\left.\mathrm{HPO}_{4}{ }^{2-}\right)$

3.6. Synthetic Analogues of Biorelated Mineral Phases and Crystallization Dynamic Modelization

3.7. Role of Proteins

4. Chemical Analysis by FTIR Spectrometry

4.1. FTIR Spectrometry Used Routinely in the Hospital

4.2. Clinical Case Characterized with Classical FTIR Spectroscopy

4.3. Enhancing Spatial Resolution with Synchrotron Radiation (SR)

4.4. Other Major Applications of FTIR Spectroscopy in Medical Science

5. Wide- and Small-Angle X-Ray and Neutron Scattering

5.1. Considering Neutron and X-ray Scattering Techniques

5.2. Determining Nanocrystal Structural Parameters

5.3. Simulations of Scattering Diagram by Debye Formulas

5104

5.4. Other Data/Information from X-ray and Neutron Scattering

6. X-ray Absorption Spectroscopy Specifically Related to SR

6.1. XANES Spectroscopy for Characterizing Pathological Calcifications

6.2. XANES Spectroscopy for the Characterization of Trace Elements

6.3. EXAFS Spectroscopy

5092

5094

5094

5095

5096

5096

5097

5097

5098

5098

5099

5099

5100

5101

5101

5101

5101

5103

5103

5103

5104

7. X-ray Fluorescence Spectroscopy and Trace Elements

7.1. Classical X-ray Fluorescence Spectrometry

7.2. X-ray Fluorescence Spectrometry on SR Facilities

7.3. Mapping at the Micrometer Scale of Pathological Calcifications

7.4. Nature of the Trace Elements in Pathological Calcifications

7.5. XRF at the Cellular Level

8. In Vivo Studies

9. Other Applications of Large-Scale Instruments for Analyzing Calcification in Medicine

10. Conclusions and Perspectives

Author Information

Corresponding Author

Notes

Biographies

Acknowledgments

References

Note Added after ASAP Publication

\section{INTRODUCTION}

Several major diseases, such as cancer and cardiovascular abnormalities, may be linked to pathological deposition of minerals or organic compounds in various tissues. ${ }^{1-3}$ Thus, the detection of such minerals or compounds and understanding the physicochemical processes associated with their formation are essential. 
As underlined by Schmidt et al., ${ }^{4}$ in Europe and the U.S., breast cancer will occur in 1 in 10 women. If clustered calcifications $^{5}$ are one of the mammographic signs of early breast cancer, their chemical nature must be determined. More precisely, calcium phosphates ( $\mathrm{CaPs}$ ) are frequently associated with malignancy, but calcium oxalates are present in benign lesions. $^{6-10}$

From a medical viewpoint, pathological calcifications ${ }^{11,12}$ refer to at least three very different families of biominerals: concretions, metastatic calcifications and dystrophic calcifications. Concretions are found in hollow organs or ducts of the body. For example, kidney stones ${ }^{13-16}$ are solid concretions of dissolved minerals in urine found in the kidney. In contrast, metastatic and dystrophic calcifications, which can be considered ectopic calcifications, ${ }^{17}$ are defined as unexpected biomineralization ${ }^{18,19}$ occurring in soft tissues. ${ }^{20}$ In the absence of a systemic mineral imbalance, dystrophic calcification is often associated with tissue alteration or necrosis. ${ }^{21}$ In contrast, metastatic calcifications resulting from mineral imbalance are more systemic and affect various tissues (e.g., vessels, lungs, kidneys). A fourth family can be considered physiological calcification (bone), which becomes pathological with diseases such as arthrosis or osteoporosis.

In all cases, complex interactions between cells and crystals are involved, as illustrated in Figure 1.

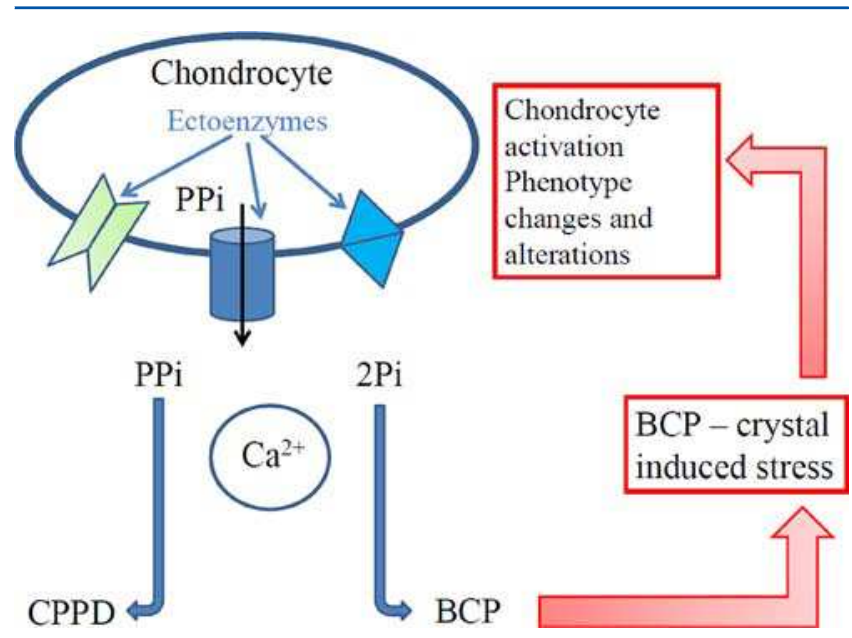

Figure 1. Simplified schematic illustrating the complex interaction between crystal (calcium pyrophosphate dihydrate [CPPD] or basic $\mathrm{CaPs}[\mathrm{BCP}]$ ) and cells. $\mathrm{PPi}$, inorganic pyrophosphate; $\mathrm{Pi}$, inorganic phosphate.

Figure 1 shows some of the biochemical mechanisms occurring between crystals and cells in cartilage (details in ref 22). Extracellular inorganic pyrophosphate (ePPi) concentration is controlled by 3 ectoenzymes: membrane glycoprotein, multipass transmembrane transporter, and tissue-nonspecific alkaline phosphatases. With decreased ePPi concentration, extracellular inorganic phosphate $(\mathrm{ePi})$ can form basic $\mathrm{CaP}$ (BCP) crystals within matrix vesicles. Through this mechanism, $\mathrm{ePPi}$ and inorganic phosphate $(\mathrm{Pi})$ imbalance determines the calcium crystal type.

Both calcium pyrophosphate dihydrate (CPPD) and BCP crystals, directly activate the articular chondrocytes responsible for a real "crystal-induced stress", similar to stresses with the previously well-known and well-described mechanical, or oxidative stress, or biochemical stresses in osteoarthritic cartilage. This cell activation may ultimately lead to significant changes in articular chondrocyte phenotype.

Different aspects of such calcifications must be taken into account to establish a significant relationship with the disease. These include chemical diversity, morphologic features at the mesoscopic and macroscopic scale, location in the organ, presence of trace elements (which could be catalytic agents), presence of molecular groups, such as carbonate groups in apatites and, finally, proteins.

In terms of chemical diversity, all pathological calcifications mainly contain CaPs. However, secreting organs such as biliary tract and kidneys show a great chemical diversity of crystalline compounds. In fact, more than 100 chemical compounds have been identified in the kidney and include calcium and magnesium salts (phosphates, carbonates, sulfates, oxalates) or organic compounds (purines, aminoacids, lipids, proteins, and drugs).

The morphologic features of the calcification must be considered, ${ }^{23,24}$ especially for concretions. For example, with kidney concretions, whewellite (calcium oxalate monohydrate) stones, depending on their morphologic features at both macroscopic and mesoscopic scales, can be associated with an alimentation disorder ${ }^{25}$ or a genetic abnormality, namely primary hyperoxaluria. ${ }^{26}$ From a physicochemical point of view, we used the terms "nanocrystals" and "crystallites" to define the structural hierarchy of these mineral concrements. Crystallites (measuring typically some tens of micrometres) are made of a collection of nanocrystals (measuring typically some hundreds of nanometres). ${ }^{27}$ Of note, we have underlined a close relationship between stone morphologic features and crystallite organization at the mesoscopic level and the effectiveness of extracorporeal shockwave lithotripsy. ${ }^{19}$

The location of the ectopic calcification in the organ is of prime importance in disease. For example, vascular calcifications may occur at different areas of the vessel wall, including the intima in atherosclerosis and the media in Mönckeberg's sclerosis. $^{28}$

We have also to consider the interface between the calcification and the biological environment. Obviously, this interface plays a significant role in the nucleation and crystal growth of the calcification. As pointed out by C. Rey et al., ${ }^{29}$ a special characteristic of biological and synthetic nanocrystalline apatites is the existence of a structured surface hydrated layer which is involved in the protein/inorganic recognition and interaction $^{30-32}$ as in the formation of dental structures. ${ }^{33}$ Regarding concretions, ${ }^{34}$ it is at this interface also that the organism will send different compounds to prevent the growth or to inhibit the fixation of the mineral.

Finally, special attention must be paid to the presence of trace elements and molecular groups at the surface or inside the mineral. ${ }^{35,36}$ These trace elements have been the subject of numerous studies in chemistry ${ }^{37}$ or medicine ${ }^{38-41}$ to elucidate their role regarding the crystal formation kinetics ${ }^{42,43}$ or the morphologic features of the mineral. ${ }^{44} \mathrm{~A}$ recent study highlighted that $\mathrm{Zn}^{45}$ may have an inhibitory effect on calcium oxalate $(\mathrm{CaOx})$ stone formation, whereas $\mathrm{Fe}$ and $\mathrm{Cu}$ could promote $\mathrm{CaOx}$ stone formation. ${ }^{46,47}$ The carbonate level of biological apatites is also an interesting feature. A close relationship was observed between the presence of bacterial imprints, ${ }^{48}$ indicative of past or current urinary tract infection, and the presence of amorphous carbonated $\mathrm{CaP}$ (or that of whitlockite) and a high ratio of $\mathrm{CO}_{3}{ }^{2-}$ to $\mathrm{PO}_{4}{ }^{3-}$ of apatite. ${ }^{49}$ 
Note that such bacterial imprints are not present in infectious struvite kidney stones. ${ }^{50}$

The presence of small amounts of other mineral ions, such as $\mathrm{Na}^{+}, \mathrm{K}^{+}, \mathrm{F}^{-}, \mathrm{OH}^{-}$, and $\mathrm{CO}_{3}{ }^{2-}$, influences the reactivity and stability of biological apatites, inducing subtle changes in their microstructural features. ${ }^{51,52}$ More precisely, high resolution electronic microscopy revealed that the incorporation of $\mathrm{Zn}$ ions in the crystal lattice of carbonate-containing apatites reduced the number of structural defects. ${ }^{53}$

In the hospital, noninvasive methods are preferentially selected for the analysis of deposits. Thus, calcifications are detected by radiography, ${ }^{54}$ with considerable effort made to improve this technique. Contrast agents ${ }^{55}$ can be used to artificially alter X-ray attenuation locally (e.g., blood vessels in an organ), and synchrotron radiation (SR) has replaced the conventional X-ray source. ${ }^{56,57}$ In fact, compared with conventional generators, the use of phase-sensitive techniques reduced the delivered dose and improved the image contrast. ${ }^{58}$ With invasive techniques, calcifications in biopsies and extracted samples can be characterized by optical microscopy after adequate coloration to allow for visualization of submillimeter calcifications. $^{59}$ Of note, staining alone is not sufficient to confirm the presence of calcification. ${ }^{60}$ Such approach is the basis of the work of anatomopathologists. Identification can be completed by other techniques routinely used in some cases: Fourier transform infrared (FTIR) ${ }^{61}$ and Raman spectroscopy, $^{62}$ as well as classical X-ray diffraction (XRD). Hospital research takes advantage of other sophisticated techniques.

This review focuses on the structural characterization of pathological calcifications mainly through $\mathrm{SR}^{63}$ and neutronrelated techniques ${ }^{64,65}$ to complete the characterization performed in the hospital. We reveal the possibilities with use of these large-scale instruments for determining the size and morphologic features of the nanocrystals contained in these biological entities and for other aspects that are crucial from a medical $^{66,67}$ and chemical viewpoint: the presence of trace elements, the molecular groups at the surface and the possibility of studying the interface between cells and mineral. Recent reviews ${ }^{6,69}$ have underlined the advantages and the limitations of different SR-related techniques used now as X-ray microprobes. $^{70,71}$ Also, a set of excellent reviews have focused on different SR techniques, from FTIR spectrometry ${ }^{72,73}$ to $\mathrm{XRD},{ }^{74-76} \mathrm{X}$-ray fluorescence (XRF), ${ }^{77,78}$ and X-ray absorption spectroscopy (XAS). ${ }^{79}$ Thus, we provide only a brief description of the physics associated with these techniques before a review of different medical or physico-chemistry research works. We discuss the following points in terms of hospital care (i.e., FTIR spectrometry), with reference to advantages of the techniques implemented for large-scale instruments from a medical viewpoint: (1) the determination of the chemical composition and the presence of molecular groups of medical importance, such carbonate by FTIR spectrometry, (2) the structure of the elementary crystals and its interface by diffraction techniques and XAS, and (3) the nature of trace elements present and a proposition to classify them by XRF. ${ }^{80}$

Of note, the ultimate goal is to use techniques usually dedicated to fundamental physics and those related to largescale facilities for characterizing pathological calcifications at the subcellular scale to (1) establish a possible link between the chemical characteristics of the calcification and the abnormality, (2) allow for an early diagnosis, and (3) revisit results provided early by more classical techniques.
We would like to describe some basic aspects of pathological calcifications from a medical and chemical viewpoint. This brief description (additional information can be obtained in excellent reviews dedicated to biomineralization processes ${ }^{81}$ ) is a prerequisite to appreciate the complexity of such objects and the need for intimate collaboration between physicist, chemist, and clinician scientific communities.

We will review some physicochemical aspects ${ }^{82}$ related to solubility, nucleation and crystal growth, especially of calcium salts encountered in pathological calcifications, and the role of proteins in these processes.

\section{MEDICAL ASPECTS REGARDING PATHOLOGICAL CALCIFICATIONS}

First, we show the different levels of complexity of pathological calcifications. Such biological entities are present almost everywhere in the human body. Their origin is complex and can be induced by different kinds of abnormalities (metabolic syndrome, genetic, infection). Also, such pathological calcifications may have a hierarchical structural organization, which can be related to the history of the patient.

\subsection{Generalities on Pathological Calcifications}

Pathological calcifications may occur in various parts of the body, namely, joints, ${ }^{83}$ brain, ${ }^{84-88}$ breast, ${ }^{89-92}$ cartilage, ${ }^{93-95}$ cardiac valves, ${ }^{96,97}$ middle ear, ${ }^{98}$ gallbladder, ${ }^{99}$ gastric system, ${ }^{100}$ heart, ${ }^{101,102}$ intestine,${ }^{103}$ kidney, ${ }^{104-10}{ }^{10}$ larynx, ${ }^{108,109}$ liver, ${ }^{110-112}$ lungs, ${ }^{113-115}$ pancreas, ${ }^{116,117}$ prostate, ${ }^{118,119}$ saliva, ${ }^{120}$ tendons, ${ }^{121}$ testicles, ${ }^{122,123}$ tooth, ${ }^{124}$ thyroid, ${ }^{125-127}$ and artery or vessels ${ }^{128-134}$ affecting adults, as well as fetuses and newborns. ${ }^{135,136}$ Calcifications of placenta have also been observed. ${ }^{137}$ Calcifications of medical devices made of polyurethane, silicones, and hydrogels have been widely reported. These devices include bioprosthetic heart valves ${ }^{138-141}$ cerebrospinal fluid shunts, mammary implants, ${ }^{142}$ contraceptive intrauterine devices, ${ }^{143}$ stents, ${ }^{144,145}$ and intraocular lens. ${ }^{146-148}$

We highlight different specific structural aspects of pathological calcification by scanning electron microscopy (SEM) observations related to major medical aspects (Figure 2).

For example, physiological calcifications are organized on different spatial scales. Pathological calcifications can be organized as well (Figure 2), and such spatial organization of the chemical phases is linked to the case history (an example is given later). For a Brushite kidney stone, the radial organization is clearly visible. Moreover, at the center of the kidney stone, apatite can be present (Figure 2B).

Figure $2 \mathrm{C}$ and $\mathrm{D}$ shows whewellite kidney stones. Crystallites of kidney stones in Figure 2C are linked to primary hyperoxaluria type 1, a rare inherited disease leading to recurrent nephrolithiasis, nephrocalcinosis, systemic oxalosis, and renal failure, ultimately requiring combined kidney and liver transplantation, ${ }^{149} \cdot{ }^{150}$ At the opposite, crystallites of kidney stones shown in Figure 2D are commonly observed for idiopathic type of whewellite stones related to a disordered alimentation. From these observations, we propose that a morphologic examination be performed before compositional analysis by means of X-ray diffraction or infrared spectroscopy, because this direct SEM examination constitutes a simple, rapid, and cheap tool that might point to the early diagnosis of primary hyperoxaluria type 1 .

Figure $2 \mathrm{E}$ and $\mathrm{F}$ shows calcifications at the surface of calcified cardiac valves. Such observations demonstrate that the 

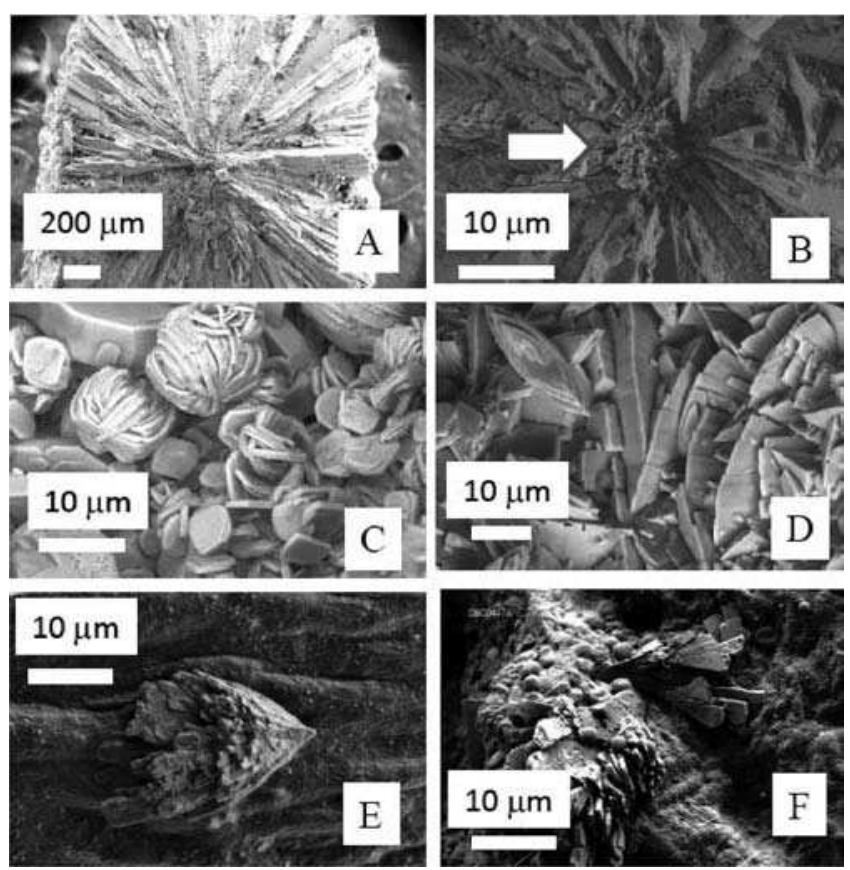

Figure 2. Spatial organization of pathological calcifications. (A) A kidney stone of brushite displays a radial distribution of acicular crystallites with a center of spherical apatites (B). Crystallites of whewhelite have various morphologic features and various agglomeration modes. Whewellite crystallites related to a genetic disease (C) have a morphologic and agglomeration type different from whewellite kidney stones related to dietary disorders. Calcifications on cardiac valve (E, F) may have different morphologic features.

morphologic features of such calcifications can be quite different. Bundles of faceted microrods are shown in Figure $2 \mathrm{E}$, and round-shaped or sphere-like, flat structures adherent to the leaflet surface are observed in Figure 2F: the first species seems to be inserted into the leaflet surface and such configuration can give some information regarding the interaction between the calcification and the tissues.

\subsection{Origins}

Figure 3 illustrates the diversity of origin of calcifications by SEM.

Hyperoxaluria in urine leads to the formation of whewellite kidney stones, whereas hypercalciuria is the origin of weddelite (calcium oxalate dihydrate) stones (Figure 3B). Infection is also a cause of kidney stones, and Figure $3 \mathrm{C}$ shows some fingerprints at the surface of spherical apatite crystallites, whereas the calcification seems to be present around the bacteria. Aging can lead to calcification; Figure $3 \mathrm{E}$ shows the presence of calcium pyrophosphate crystals at the surface of the cartilage. In Figure 3D, we can observe the presence of 2,8dihydroxyadenine (2,8-DHA) crystals the formation of which is due to adenine phosphoribosyltransferase (APRT) deficiency related to a genetic disease. APRT deficiency is a rare, but potentially severe autosomal-recessive inborn error of purine metabolism that is largely underdiagnosed. ${ }^{151}$

Several works have underlined that the cell environment may change its functioning. Recently, Giachelli ${ }^{152}$ investigated the role of phosphate level in transforming the vascular phenotype of cultured human aortic smooth muscle cells to an osteogenic phenotype, to create a predisposition for calcification. Sun et al. ${ }^{153}$ demonstrated that BCP crystals stimulate the uptake or endocytosis of DNA plasmid and that this is accomplished
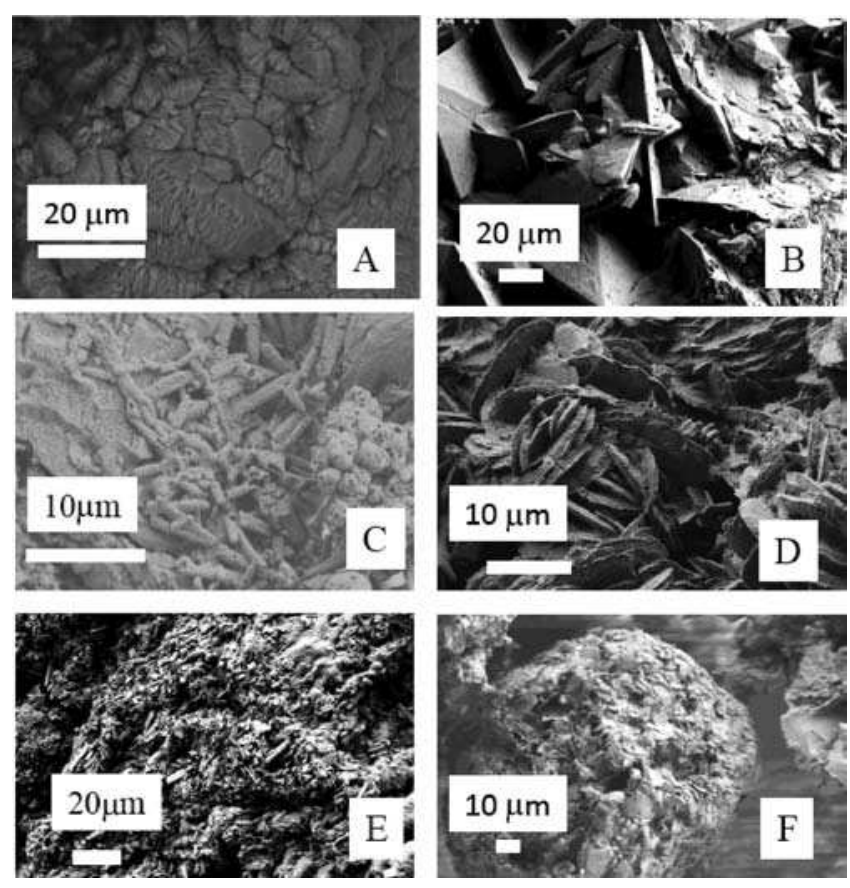

Figure 3. Examples of calcification: kidney stones related to hyperoxaluria (A) and hypercalciuria (B), presence of bacterial imprints with infection (C), presence of dihydroxyadenine crystals with genetic disease (D), calcification on cartilage due to aging (E), cholesterol calcifications present in the biliary system (F) are also associated with alimentation disorder.

mainly by rendering the cells more permeable. Also, Hsu et al. ${ }^{154}$ showed that bicarbonate buffer could provide a dynamic and rapid transitional increase in $\mathrm{pH}$ of extracellular fluids, thereby creating a favorable condition for the initiation of vesicle-mediated calcification under pathological conditions. Recent observations ${ }^{155}$ have suggested that ectopic calcification, like bone biomineralization, is an actively regulated process. Breast tissue is heterogeneous, associating connective and glandular structures, which grow and change cyclically under hormonal regulation. Hormones are thought to be the main determinant factor of the major benign and malignant abnormalities encountered in the breast. ${ }^{156,157}$

Several mechanisms are involved in calcification. For example, with prostatic calculi, Klimas et al. ${ }^{158}$ highlighted two related mechanisms: calcification of corpora amylacea and simple precipitation of prostatic secretion. The genesis of pathological calcifications of the basal ganglia has been linked to more than 30 medical conditions, including infectious, metabolic, and genetic syndromes. ${ }^{159,160}$

In many tissues of the body, inflammation often induces small calcium deposits. ${ }^{161}$ For example, microcalcifications are less commonly associated with prostate cancer than with benign prostatic ducts alterations and aging. ${ }^{162}$ In contrast, intratesticular microlithiasis is highly associated with testicular cancer. ${ }^{163}$ Also, some abnormalities such as cystinosis, a metabolic disease, are characterized by accumulated cystine in different organs and tissues, thus leading to potentially severe organ malfunctioning. ${ }^{164}$

Finally, the possible involvement of nanobacteria could be considered in the mechanism for pathogenic intra- and extracellular calcification and concretion formation. ${ }^{165-170}$ Note that recent results definitively ruled out the existence of 
"nanobacteria" as living organisms and pointed out the paradoxical role of fetuin. ${ }^{171}$

\subsection{Concretion on Ectopic Calcification}

Pathological calcification may have a complex organization from the history of the abnormality. For example, atherosclerosis involves early deposition of cholesterol, cholesterol esters, and related lipid compounds (and their oxidation products) on the inside walls of arteries. ${ }^{172}$ In advanced stages, atherosclerotic plaques may become calcified by the codeposition of $\mathrm{CaP}$. Therefore, $\mathrm{CaP}$ nucleation and crystal growth on cholesterol and cholestanol surfaces must be studied from a supersaturated simulated body fluid. ${ }^{173}$

With concretion, the existence of intracrystalline proteins and amino acids in whewellite was demonstrated by X-ray synchrotron diffraction studies. As found by Fleming et al. ${ }^{174}$ their presence have implications for the destruction of $\mathrm{CaOx}$ crystals formed in the urinary tract and the prevention of kidney stones (KS).

In the kidney, ectopic calcification, named Randall's plaque $(\mathrm{RP}),{ }^{175}$ is a support for the nucleation and growth of concretion (i.e., kidney stone; Figure 4A). ${ }^{176}$ Recently,
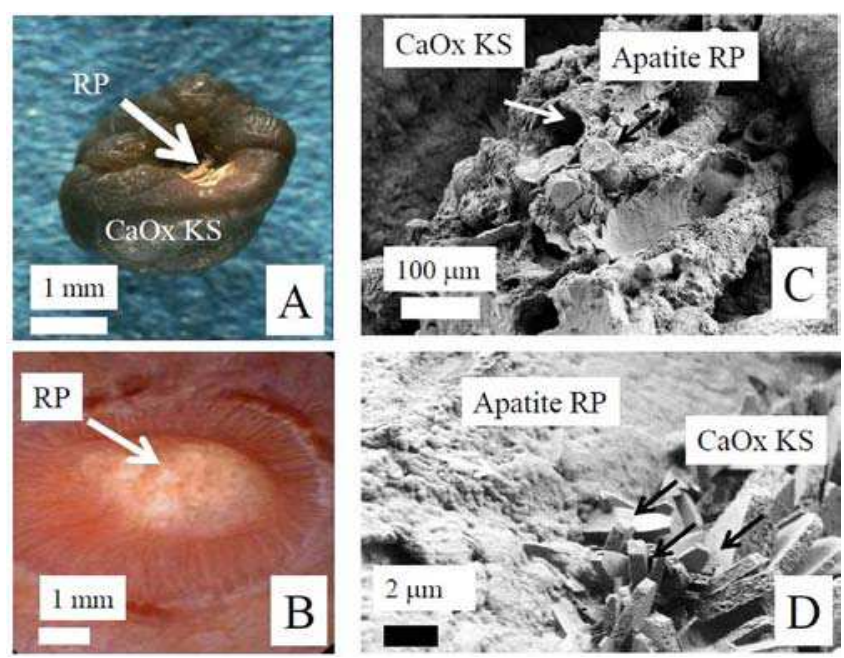

Figure 4. (A) Randall's plaque (RP) made of apatite on top of a kidney stone of whewellite ( $\mathrm{CaOx} \mathrm{KS})$. (B) RP at the surface of the papilla. SEM micrographs: (C) RP appears as a complex structure containing calcified tubules; (D) of interface area between RP and a whewellite stone.

endoscopy revealed RP commonly present on papilla of calcium oxalate stone formers. ${ }^{177}$ Evan et al., ${ }^{178}$ taking advantage of percutaneous nephrolithotomy procedures in 15 recurrent calcium oxalate stone formers, showed that interstitial apatite plaque particles first appear in the basement membranes of the thin loops of Henlé. In addition, the authors showed that stone formation activity is proportional to the surface of papillae covered by $\mathrm{RP}^{179}$ and that the mean fractional plaque coverage is higher in calcium oxalate stone formers with the highest urinary calcium concentration. ${ }^{180}$ This situation is the subject of numerous studies investigating the interface between the concretion and the ectopic calcification as well as determining the nature of proteins present to prevent the formation of RP. ${ }^{181}$

SEM at the mesoscopic scale can reveal structural information. As previously described, Figure 4A shows RP at the surface of the calcium oxalate kidney stone ( $\mathrm{CaOx} \mathrm{KS}$ in
Figure 4A). These $\mathrm{CaP}$ deposits of carbonated apatite likely from both interstitium and neighboring collecting ducts may cover the surface of the papillary epithelium (RP in Figure 4B). SEM at the mesoscopic scale (Figure 4C) shows the plaque appearing as a complex structure containing calcified tubules and vessels (white arrows) and tubules filled by carbonated apatite plugs (black arrows). The smooth part of the plaque (white arrowhead) suggests that a layer of carbonated apatite, probably from neighboring tubules, covers the papilla epithelium. Finally, SEM allows for a detailed description of the interface area between an RP and a whewellite stone (Figure 4D). This technique shows randomly distributed $\mathrm{CaOx}$ monohydrate crystals (right) trapped in the carbonated apatite of RP (left). Such structural description can reveal the biochemical mechanism responsible for the development of the kidney stone from the RP. The presence of RP made of carbonated apatite spherules (white arrow in Figure 4D) appears joined by an unstructured material, identified as proteins using infrared spectroscopy; this biomaterial made of a mineral nanocrystals and protein acts as a glue to fix $\mathrm{CaOx}$ crystallites (black arrows in Figure 4D).

\section{PATHOLOGICAL CALCIFICATIONS AND PHYSICOCHEMISTRY}

Lowenstam $^{182,183}$ has defined two modes of biomineralization: ${ }^{184,185}$ biologically induced and biologically controlled biomineralization. In the first case, chemical variations as a result of the metabolic activity of microorganisms lead to precipitation in the external environment of the bacteria. Biominerals are thus not directly associated with cellular structures, whereas a specific nucleation intracellularly or on the cell wall is observed during the biologically controlled process.

The study of biomineralizations is an active interdisciplinary field. ${ }^{186}$ Biomineralization covers the full spectrum of issues devoted to the study of minerals produced by living organisms. ${ }^{187}$ From a fundamental viewpoint, crystallization may be induced in metastable supersaturated biological or synthetic solutions by spontaneous nucleation when a certain degree of supersaturation is reached (homogeneous nucleation) or by seed crystals or polymeric substances (heterogeneous nucleation). Although seed crystals of the growing substance are usually the most effective, the crystallization may also take place on the surface of other materials/substances which offer a good crystal lattice or surface structure to match the main crystalline plane of the substance being precipitated.

In biological mineralization, epitaxial crystal growth is of prime importance for understanding the formation of teeth and bone, as well as pathological processes such as urinary calculi. The formation of pathological calcifications involves complex mechanisms that, in most cases, are still to be elucidated. For example, stones form in a complex environment with constant formation of urine at a variable flow rate, $\mathrm{pH}$ and composition. Although supersaturation must be reached for the precipitating phase, it alone does not predict stone formation. Other factors such as the presence of inhibitors of crystal growth, the matrix, sites of formation and retention, and accretion of smaller entities, may be important.

The study of pathological calcifications is thus related to some fundamental physical-chemical aspects, such as the solubility of mineral phases, nucleation and crystal growth and/ or aggregation processes and interfacial phenomena (adsorption and surface reactions based on interaction between mineral and proteins or ions as crystallization promoters or inhibitors, 

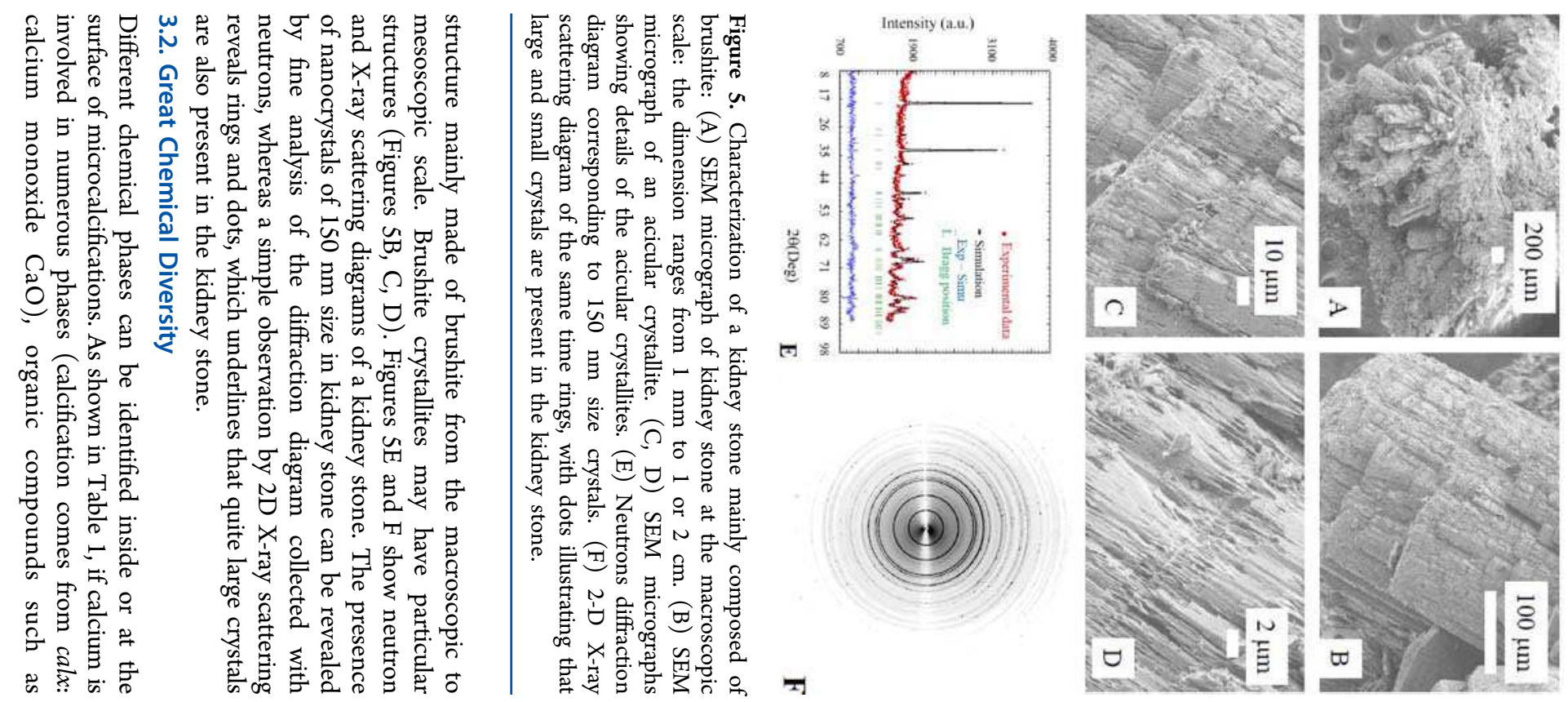

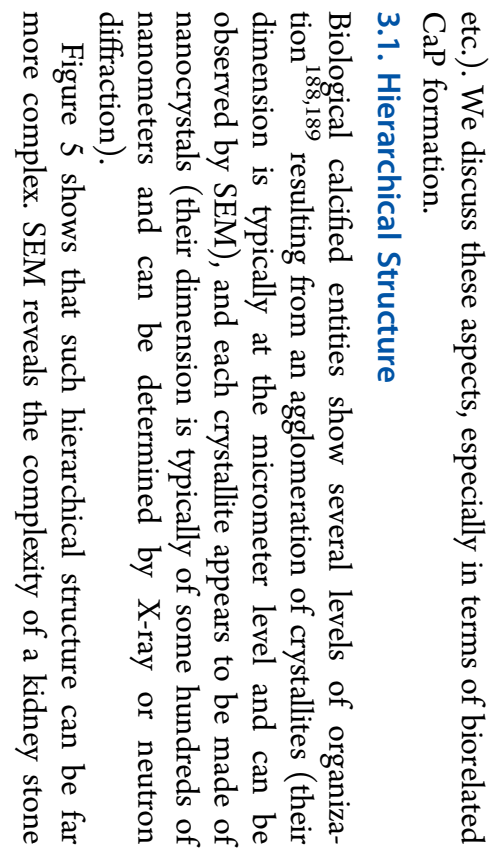

Table 1. Chemical Formula of Compounds Found in Pathological Calcifications in Several Tissues and Organs compounds and their chemical formula

joints ${ }^{191-194} \quad$ calcium pyrophosphate dihydrate $\left(\mathrm{CPPD}, \mathrm{Ca}_{2} \mathrm{P}_{2} \mathrm{O}_{7} \cdot 2 \mathrm{H}_{2} \mathrm{O}\right)$, octacalcium phosphate $\left(\mathrm{OCP}, \mathrm{Ca}_{8}\left(\mathrm{HPO}_{4}\right)_{2}\left(\mathrm{PO}_{4}\right)_{4} \cdot 5 \mathrm{H}_{2} \mathrm{O}\right)$, carbonated apatite $\left(\mathrm{CA}, \mathrm{Ca} a_{10-x+u} \square,{ }_{x-u}\left(\mathrm{PO}_{4}\right)_{6-x}(\mathrm{CO})_{x}(\mathrm{OH})_{2-x+2 u}\right.$ with $\square$

breast $^{195}$ corresponding to vacancy, $x \leq 2$ and $u \leq x / 2)$, tricalcium phosphate $\left(\mathrm{Ca}_{3}\left(\mathrm{PO}_{4}\right)_{2}\right)$ Whitlockite $\left(\mathrm{Ca} 9 \mathrm{Mg}\left(\mathrm{HPO}_{4}\right)\left(\mathrm{PO}_{4}\right)_{6}\right.$

apatite, weddellite (calcium oxalate dihydrate (COD), $\mathrm{CaC}_{2} \mathrm{O}_{4} \cdot 2 \mathrm{H}_{2} \mathrm{O}$ )

kidney ${ }^{196-198} \quad$ calcium phosphates carbonated apatite, octacalcium phosphate, whitlockite, amorphous carbonated calcium phosphate $(\mathrm{ACCP})$, brushite $\left(\mathrm{CaHPO}_{4} \cdot 2 \mathrm{H}_{2} \mathrm{O}\right)$; magnesium ammonium phosphates struvite

calcium phosphates carbonated apatite, octacalcium phosphate, whitlockite, amorphous carbonated calcium phosphate $(\mathrm{ACCP})$, brushite $\left(\mathrm{CaHPO}_{4} \cdot 2 \mathrm{H}_{2} \mathrm{O}\right)$; magnesium ammonium phosphates struvite
$\left(\mathrm{NH}_{4}\right) \mathrm{MgPO}_{4} \cdot 6 \mathrm{H}_{2} \mathrm{O}$, dittmarite $\left(\mathrm{NH}_{4}\right) \mathrm{MgPO}_{4} \cdot \mathrm{H}_{2} \mathrm{O}$; magnesium phosphates newberyite $\left(\mathrm{MgHPO}_{4} \cdot 3 \mathrm{H}_{2} \mathrm{O}\right)$; calcium oxalate whewellite $($ calcium oxalate monohydrate $(\mathrm{COM}))$ CaC $\left.\mathrm{O}_{4} \cdot \mathrm{H}_{2} \mathrm{O}\right) ;$ weddelite $\left(\mathrm{NH}_{4}\right) \mathrm{MgPO}_{4} \cdot 6 \mathrm{H}_{2} \mathrm{O}$, dittmarite $\left(\mathrm{NH}_{4}\right) \mathrm{MgPO}_{4} \cdot \mathrm{H}_{2} \mathrm{O}$; magnesium phosphates newberyite $\left(\mathrm{MgHPO}_{4} \cdot 3 \mathrm{H}_{2} \mathrm{O}\right)$; calcium oxalate whewellite (calcium oxalate monohydrate $\left.(\mathrm{COM})\right)$ CaC $\left.\mathrm{C}_{2} \mathrm{O}_{4} \cdot \mathrm{H}_{2} \mathrm{O}\right)$; weddelite
$\left(\mathrm{COD}, \mathrm{CaC}_{2} \mathrm{O}_{4}, 2 \mathrm{H}_{2} \mathrm{O}\right)$; caoxite (calcium oxalate trihydrate $\left.(\mathrm{COT}), \mathrm{CaC}_{2} \mathrm{O}_{4}, 3 \mathrm{H}_{2} \mathrm{O}\right)$; uric acid anhydrous, monohydrate and dihydrate polymorphs; urate salts ammonium hydrogen urate, sodium hydrogen urate, sodium potassium urate, calcium hydrogen urate, magnesium hydrogen urate, etc; xanthine, 2,8-dihydroxyadenine cystine, leucine, tyrosine

liver ${ }^{199-201}$ and cholesterol, calcium bilirubinates, calcium carbonate polymorphs (calcite, aragonite, vaterite) $\mathrm{CaCO}_{3}$; calcium phosphates carbonated apatite, amorphous carbonated calcium phosphate, calcium palmitate,

$\begin{array}{cc}\begin{array}{l}\text { liver } \\ \text { gallbladder }\end{array} \text { and }^{204} & \begin{array}{c}\text { cholesterol, calcium bilirubinates, calcium carbonate polym } \\ \text { bile salts }\end{array} \\ \text { pancreas }^{205-207} & \text { calcium carbonate polymorphs (calcite, aragonite, vaterite) }\end{array}$

prostate $^{208-211}$

calcium phosphate carbonated apatite, whitlockite, brushite; calcium citrate tetrahydrate; calcium oxalate whewellite, weddellite

salivary
glands

glands ${ }^{212-21}$

aorta $^{215,216}$

$\operatorname{skin}^{217,218}$ and

calcium phosphates hydroxyapatite, carbonated apatite, whitlockite, amorphous carbonated calcium phosphate, octacalcium phosphate

whitlockite, carbonated apatite

muscle $^{219-222}$ carbonated apatite 
cholesterol or uric acid can also be the main constituent. Particularly in kidney, amino acids such as cystine can be found because of its low solubility.

Such biological entities may also have a drug origin. ${ }^{190}$ Druginduced renal calculi represent $1 \%$ to $2 \%$ of all renal calculi, including two categories: those resulting from the urinary crystallization of a highly excreted, poorly soluble drug or metabolite and those due to the metabolic effects of a drug: Indinavir or atazanavir used in HIV-infected patients, sulfonamides, especially sulfadiazine, and triamterene are the most frequently involved. The name and the chemical formula of compounds found in pathological calcifications are reported in Table 1 .

Table 1 shows that $\mathrm{CaP}$ apatite is present in numerous pathological calcifications, which is consistent with the content of $\mathrm{Ca}$ in the human body (about $1 \mathrm{~kg}$ for a $72-\mathrm{kg}$ body). From a chemical viewpoint, the specificity of calcium results from its coordination geometry often being irregular and strongly influenced by the second coordination sphere. ${ }^{223}$

Apatite is generally described by the formula $\mathrm{Me}_{10}\left(\mathrm{XO}_{4}\right)_{6}(\mathrm{Y})_{2}$ with $\mathrm{Me}$ representing a metal $\left(\mathrm{Ca}^{2+}, \mathrm{Sr}^{2+}\right.$, $\mathrm{Mg}^{2+}, \mathrm{Pb}^{2+}, \mathrm{Na}^{+}, \mathrm{K}^{+}, \mathrm{Eu}^{3+}, \ldots$, a vacancy), $\mathrm{XO}_{4}$ representing an anion $\left(\mathrm{PO}_{4}{ }^{3-}, \mathrm{SO}_{4}{ }^{2-}, \mathrm{SiO}_{4}{ }^{4-}, \mathrm{CO}_{3}{ }^{2-}, \mathrm{HPO}_{4}{ }^{2-}, \ldots\right), \mathrm{Y}$ representing an anion $\left(\mathrm{OH}^{-}, \mathrm{Cl}^{-}, \mathrm{F}^{-}, \mathrm{CO}_{3}{ }^{2-}, \mathrm{S}^{2-}, \mathrm{O}_{2}{ }^{2-}, \ldots\right.$ or a vacancy). For carbonated apatite for example: $\mathrm{Ca}_{10-x+u} \square_{x-u}\left(\mathrm{PO}_{4}\right)_{6-x}\left(\mathrm{CO}_{3}\right)_{x}(\mathrm{OH})_{2-x+2 u}$ with $\square$ corresponding to vacancy, $x \leq 2$ and $u \leq x / 2 .{ }^{224}$ The apatite structure was first determined on fluorapatite crystals $\left(\mathrm{Ca}_{5}\left(\mathrm{PO}_{4}\right)_{3} \mathrm{~F}\right)$ by Naray-Szabo (1930) and was confirmed to adopt $P 6_{3} / \mathrm{m}$ symmetry. $^{225}$

More precisely, we recall that hydroxyapatite (HAP, $\left.\mathrm{Ca}_{5}\left(\mathrm{PO}_{4}\right)_{3}(\mathrm{OH})\right)$ can be described as an hexagonal stacking of $\mathrm{PO}_{4}{ }^{3-}$ groups with two kinds of tunnels parallel to the $c$ axis. The first one coincides with the ternary axis of the structure and is occupied by $\mathrm{Ca}^{2+}$, noted $\mathrm{Ca}$ (I) ions. The second one is bounded by oxygen and other calcium ions, noted Ca (II) ions, and is occupied by $\mathrm{OH}^{-}$ions. Ca (I) and Ca (II) are present in a ratio of 2 to $3 .{ }^{226}$ The diameter of such tunnels ( 3 Á) gives apatites properties of an ion exchanger but only at high temperatures, and they can also act as a host to small molecules and to different cations.

Biological apatites share different structural and chemical properties. A first structural specificity emerges from the lack of $\mathrm{OH}^{-}$as noticed by several studies based on infrared spectroscopy and inelastic neutron scattering. ${ }^{227}$ Cho et al. measured an $\mathrm{OH}^{-}$content of human cortical bone of about $20 \%$ of the amount expected in stoichiometric HAP. ${ }^{228}$ As noted by Vallet-Regi and Gonzalez-Calbet, crystals are nanometer in size, with an average length of $50 \mathrm{~nm}, 25 \mathrm{~nm}$ in width, and thicknesses of just $2-5 \mathrm{~nm}$, scattered in the organic matrix. ${ }^{229}$ This small size is a crucial factor related to the solubility of biological apatites as compared with geological apatites. Also, alterations of these structural characteristics have been considered a consequence of major abnormalities such as osteoporosis. $^{230}$ Biological apatite crystals displaying nanosize dimensions are non stoichiometric apatites: the presence of anionic $\left(\mathrm{OH}^{-}\right)$and cationic $\left(\mathrm{Ca}^{2+}\right)$ vacancies has been evidenced. The localization of these cationic vacancies has to be determined.

\subsection{Solubility of Mineral Phases Involved in Pathological Calcifications}

$\mathrm{CaPs}$ are involved in the calcium and phosphorus metabolism in living organisms through dissolution/precipitation processes related to controlled (normal) or uncontrolled (pathological) local physicochemical conditions.

The solubility product is an important variable in precipitation and dissolution processes of synthetic or biological mineral phases, such as carbonated apatites and other biorelated CaPs. ${ }^{231}$ The formation of CaPs is highly sensitive to the $\mathrm{pH}$ of the milieu because of the reactivity of orthophosphate ions with $\mathrm{H}_{3} \mathrm{O}^{+}$according to the following reactions:

$$
\begin{aligned}
& \mathrm{PO}_{4}{ }^{3-}+\mathrm{H}_{3} \mathrm{O}^{+} \rightleftarrows \mathrm{HPO}_{4}{ }^{2-}+\mathrm{H}_{2} \mathrm{O} \\
& \mathrm{HPO}_{4}{ }^{2-}+\mathrm{H}_{3} \mathrm{O}^{+} \rightleftarrows \mathrm{H}_{2} \mathrm{PO}_{4}{ }^{-}+\mathrm{H}_{2} \mathrm{O} \\
& \mathrm{H}_{2} \mathrm{PO}_{4}{ }^{-}+\mathrm{H}_{3} \mathrm{O}^{+} \rightleftarrows \mathrm{H}_{3} \mathrm{PO}_{4}+\mathrm{H}_{2} \mathrm{O}
\end{aligned}
$$

Considering the various equilibria and their corresponding acidity constant, hydrogenphosphate ions are the main ionic species in solution at $37{ }^{\circ} \mathrm{C}$, with $\mathrm{pH}$ in the range 2.15 and $12.35\left(2.15<\mathrm{pH}<7.2\right.$ for $\mathrm{H}_{2} \mathrm{PO}_{4}{ }^{-}$and $7.2<\mathrm{pH}<12.35$ for $\left.\mathrm{HPO}_{4}{ }^{2-}\right){ }^{232} \mathrm{CaPs}$, including both $\mathrm{HPO}_{4}{ }^{2-}$ and $\mathrm{PO}_{4}{ }^{3-}$, occur in mineralized tissues and various pathological calcifications. Depending on the $\mathrm{pH}$, composition and temperature of the crystallization milieu (synthetic solutions or biological fluids), several $\mathrm{CaPs}$ can precipitate (amorphous $\mathrm{CaP}$, dicalcium phosphate dihydrate (DCPD, brushite), octacalcium phosphate pentahydrate (OCP), apatite, whitlockite; see Table 1). ${ }^{233}$

The solubility of CaPs is highly affected by the presence of $\mathrm{CO}_{2}$ in the surrounding solution. Carbonate ions can substitute for phosphate ions in the apatite lattice and even if the amount of carbonate incorporated is relatively low (3-5\%), its presence influences the crystallinity, solubility and acid reactivity to a significant extent. Solubility isotherms are shifted toward higher Ca concentration (solubility increase) in solution at $\mathrm{pH}>7$, probably because of the formation of $\mathrm{CaHCO}_{3}{ }^{+}$complex in solution. ${ }^{234}$ At $\mathrm{pH}>6.9$, most $\mathrm{CaP}$ compounds are more soluble than is calcite $\mathrm{CaCO}_{3}$. Under physiological conditions, the presence of proteins and amino acids may favor $\mathrm{CaP}$ dissolution, because they can form a complex with calcium. In contrast, under certain conditions, the presence of $\mathrm{H}_{3} \mathrm{O}^{+}$ions or of magnesium ions, for example, calcium ions from organic complexes can be released because of the formation of more stable magnesium complexes, thus favoring $\mathrm{CaP}$ precipitation.

\subsection{Nucleation and Crystal Growth}

Crystallization of a phase involves two steps: nucleation and crystal growth. Primary nucleation can be classified as homogeneous if it occurs within the solution or as heterogeneous if it is induced by foreign particles/surfaces. ${ }^{155}$ According to the classical theory of precipitation, nucleation represents an activation barrier to the spontaneous precipitation of a solid phase from a supersaturated solution essentially related to the creation of interfacial energy. Crystallization at surfaces (heterogeneous nucleation and crystal growth) may be induced at supersaturations lower than those required for spontaneous precipitation. Consequently, in the presence of a foreign body or surface, the overall free energy change associated with the formation of a critical nucleus under heterogeneous conditions must be less than the corresponding free energy change associated with homoge- 
neous nucleation. ${ }^{235}$ However, the presence of adsorbed molecules may change the interfacial energy in solution and stabilize smaller nuclei than in solutions without adsorbate.

Epitaxy or oriented overgrowth is a special case of heterogeneous nucleation whereby the growth of the nuclei on the substrate follows a specific orientation. ${ }^{155,156}$ The definite orientation in the crystalline overgrowth requires the formation of a nucleus consisting of an immobile monolayer of regular atomic patterns more or less fitting with the lattice spacing of the crystalline substrate. ${ }^{236}$

Boistelle and Rinaudo ${ }^{237}$ showed in vitro the epitaxial growth and phase transition between anhydrous and hydrated polymorphs of uric acid, which can explain the formation and evolution of these two compounds often found in urinary calculi. $\mathrm{Pak}^{238}$ revealed the important role brushite can have in the formation of calcium-containing renal stones. This crystalline phase, identified in stone-forming urine and stones, may undergo phase transformation to hydroxyapatite or cause heterogeneous nucleation or epitaxial growth of calcium oxalate. $^{239}$

An interesting configuration is given by results from Omar et al. ${ }^{240}$ indicating that although intact bacterial cells do not provide suitable sites for heterogeneous nucleation in crystallization processes, alterations to them caused by changes in environmental conditions or processes that lead to autolysis can result in such a process.

\subsection{Important Markers of Biomineralization $\left(\mathrm{CO}_{3}{ }^{2-}\right.$ and $\mathrm{HPO}_{4}{ }^{2-}$ )}

Apatitic CaPs can accommodate a wide range of ion substitutions that can modify their physical-chemical and biological properties. The most interesting possibilities are observed with nanocrystalline apatites, which can be found in many normal and pathological calcifications. The ability of both biological and synthetic apatites to evolve and adapt to their surrounding environment is related to their low crystallinity and the extent of the hydrated surface layer containing the labile nonapatitic species. ${ }^{161,241}$ Indeed, these compounds are characterized by the existence of a hydrated layer of loosely bound mineral ions (labile ions) on the crystal surface, which can be easily exchanged in the environmental milieu. This layer offers the possibility of trapping mineral ions and active molecules. More generally, depending on their location in the apatitic nanocrystals, foreign ions may be spontaneously released by ion exchange involving calcium ions from the surrounding fluids or by cell-mediated dissolution processes. ${ }^{242}$ Altered bulk properties (dissolution, dimensions, crystal perfection) or surface properties (surface charge and energy, surface defects, protein binding ability) can directly or indirectly affect the behavior of cells.

Carbonate may play a key role in the crystallization kinetics and the morphologic features of apatite crystals. For example, Kapolos et al. ${ }^{243}$ suggested that carbonate incorporated in apatite growing on seed crystals caused changes in their morphologic features, favoring plate-like crystal formation. However, the location of carbonate $\left(\mathrm{CO}_{3}{ }^{2-}\right)$ in the apatite lattice has been controversial. ${ }^{244}$

Like carbonate ions, hydrogenphosphate ions $\left(\mathrm{HPO}_{4}{ }^{2-}\right)$ appear to be an important marker of nanocrystalline apatites in general and in bone mineral in particular; their concentration has been shown to decrease upon aging/maturation. These ions are present at high concentrations in newly formed apatite crystals and in young bone and gradually diminish with time (maturation). ${ }^{161,173}$ The presence and level of nonapatitic hydrogenphosphate groups can determine the structure of biorelated apatites and, most importantly, their function and evolution. $^{245}$

\subsection{Synthetic Analogues of Biorelated Mineral Phases and Crystallization Dynamic Modelization}

Because of the complexity and heterogeneity of composition and structure found in normal or pathological biological calcified systems (Table 1), synthetic analogues of such biominerals or biological fluids can be used to shed light on the biomineral mode of formation and physicochemical properties in vivo with in vitro model systems. ${ }^{246-250}$ The synthetic analogues (standards) of the mineral phases involved in pathological calcifications (nanocrystalline apatites, brushite, OCP, and other biorelated calcium and magnesium phosphates, calcium carbonate and calcium oxalate) can be prepared by precipitation in aqueous solution. The availability of such synthetic analogues allows to study the physical-chemical properties and reactivity of these $\mathrm{CaP}$ phases separately or together and to determine the effect of some promotors or inhibitors of their formation and/or evolution in vitro. Then, we can take advantage of this approach involving synthetic analogues for screening various components with potential therapeutic activity to prevent pathological calcifications.

Several studies have reported on the use of the (dual) constant composition crystal growth technique (i.e., constant temperature, ionic strength, supersaturation and ion concentration in solution) for the dynamic study of stone-forming minerals on the surface of other crystalline phases, cellular material and immobilized macromolecules. ${ }^{251,25 \frac{2}{2}}$ Campbell and co-workers ${ }^{253}$ showed significant differences in the inhibiting and nucleating potential of whewellite crystallization on hydroxyapatite (HAP) seeds in the presence of various polyelectrolytes and proteins (poly-L-glutamic and poly-Laspartic acids, human serum albumin) introduced in solution or adsorbed on seed surface. Lanzalaco et al. ${ }^{254}$ tested the effect of urinary and matrix (kidney stones) macromolecular components on whewellite crystallization using the same technique. Recently, Tang et al. ${ }^{255}$ studied the crystallization of whewellite in slightly acidic conditions: the authors showed whewellite crystallization induced by the presence of brushite crystals, readily formed in such $\mathrm{pH}$ conditions, and, once formed, grew at the expense of brushite crystals (dissolution of brushite crystals). These results reveal the crucial role brushite may play in the initiation of whewellite crystal formation. In addition, using the dual constant composition technique, Tang et al. ${ }^{175}$ discussed the effect of uric acid and/or citrate ions in the supersaturated solution on the aggregation state of formed whewellite crystals.

The nucleation and crystal growth of $\mathrm{CaCO}_{3}$ polymorphs can also be studied by a constant composition crystal growth technique. Kanakis et al. $^{256}$ reported a study of the crystallization of vaterite $\mathrm{CaCO}_{3}$ on a bioprosthetic cardiovascular valve with or without sodium alginate as anticalcification treatment.

In addition, (dual) constant composition crystal growth can also allow to study the dissolution kinetics of these mineral phases. $^{257}$

The use of synthetic urine-like calcium-rich or oxalate-rich solution such as $\mathrm{CaOx}$ dihydrate ${ }^{258}$ for in vitro studies is of great interest to better evaluate the components involved in crystallization. 
Finally, using atomic force microscopy configured with tips modified with biologically relevant functional groups, Sheng et al. compared the adhesion strengths of the morphologically important faces of whewellite and weddelite. ${ }^{198}$ These measurements seem to provide direct experimental evidence, at the near molecular level, for poor adhesion at weddelite. ${ }^{259}$

\subsection{Role of Proteins}

The control of crystal nucleation and growth by proteins has numerous consequences in understanding the basic mechanisms of calcification. Besides the wealth of information about the mineral and the matrix of normal or pathological calcified tissues, many questions are still unanswered, especially concerning the essential components involved in the initiation of calcification (nucleation) and in the regulation of crystal growth.

For example, urinary proteins, such as the Tamm-Horsfall protein $^{260-262}$ nephrocalcin, ${ }^{263-265}$ osteopontin ${ }^{266-268}$ and human serum albumin ${ }^{269}$ are believed to have potential to influence the crystallization of calcium oxalate. Rosenthal et al. ${ }^{270}$ showed that osteopontin promotes CPPD crystal formation in a well-characterized, chondrocyte-based model. Osteopontin is present in articular cartilage affected by CPPD deposition and may be an important factor in the development of CPPD crystals in vivo. Other studies reported the modulation of $\mathrm{CaOx}$ crystallization by osteopontin and synthetic aspartic acid-rich peptides. ${ }^{271}$

Cheung et al. ${ }^{272}$ studied the specific inhibition of BCP and calcium pyrophosphate crystal-induction of metalloproteinase synthesis by phosphocitrate. The loss of activity of natural calcification inhibitors changes tissue properties and promotes pathological processes. ${ }^{273}$

Several attempts have been made to classify proteins as promotors or inhibitors of biomineralization; most authors have used model systems for such in vitro studies. However, because of the variety of effects depending on their concentration and/or conformation, classifying them is difficult. ${ }^{274}$ Human serum albumin was found to nucleate COM crystals when immobilized on hydroxyapatite. ${ }^{172}$ Addadi et al. ${ }^{275}$ reported that the same macromolecule that acts as a specific inhibitor of crystal growth when in solution, can operate as a template for oriented crystal nucleation when adsorbed on a solid substrate in the correct conformation. These examples suggested that contradictory effects, probably resulting from complex processes, may be due to the protein source and purity, as well as the assay system. Moreover, Mueller and Sikes ${ }^{276}$ suggested the existence of two general classes of inhibitors, those affecting nucleation and those affecting growth, because the mechanisms of nucleation and/or transformation of $\mathrm{CaP}$ and growth differ.

One of the most interesting features is the dose-dependent behavior noticed with several compounds. Combes et al. showed that depending on the range of protein concentration in solution, bovine serum albumin (BSA) can have a dual role and act as a promotor or inhibitor of nucleation and growth of octacalcium phosphate on type I collagen. ${ }^{277,278}$ Several years before, Ebrahimpour et al. ${ }^{279}$ reported similar observations for the influence of human serum albumin, adsorbed and in solution, on $\mathrm{CaOx}$ nucleation and growth on hydroxyapatite.

The interpretation of these antagonist effects is based on two physical-chemical phenomena related to adsorption: the effect on nucleation rate and on crystal growth. With adsorption from solution, the interfacial tension should decrease in the presence of adsorbing molecules. Thus, the energy needed for nucleation, which is related to surface creation, will decrease if adsorbing molecules are present, and nucleation will be easier: for a given supersaturation, the nucleation ability in a solution containing adsorbing protein is greater, and multiplication of the nuclei will occur as a consequence of adsorption, as compared with a system without adsorbing protein. In most cases, the effect of protein adsorption on the nucleation process can be more complex because adsorption can occur on the substrate and the nuclei. Proteins may then delay the crystal growth process because of their presence at the solution-crystal interface, but this rarely results in the complete inhibition of crystal growth, and crystals continue to grow at a slower rate, possibly with modification of their morphologic features. The slowing down of crystal growth is related to the coverage of the crystal surface generally corresponding to a Langmuir adsorption isotherm, which is related to the concentration of the protein in solution. ${ }^{280,281}$ In addition to these thermodynamic considerations, kinetic phenomena must be considered. Because of their sizes, the proteins diffuse less rapidly than do mineral ions. The progressive depletion of adsorbing proteins occurring locally, related to nucleation and mineral surface creation, may result in an increase exposition of bare mineral surface and an increase of crystal growth, often observed as a "burst" of crystal growth at a rate much higher than that observed without proteins.

These are general phenomena that may occur with any protein adsorbing on mineral crystals to a greater or lesser extent. The borderline between activation and inhibition of the growth rate may vary for each protein, and some might never reach a concentration high enough to exhibit a global inhibition effect. The overall precipitation rate (sum of new nucleus formation and nucleus growth rate), which is the only experimental factor that most authors consider can lead to a variety of behaviors and may explain the contradictory results concerning the effect of proteins on crystal growth. ${ }^{282-284}$ Nevertheless the local amount of adsorbing proteins appears to be an important variable to consider before assessing inhibitor or activator effects on calcification.

This review reveals the difficulties in classifying a protein as a promotor, inhibitor or both of mineral precipitation depending on the system used and the range of protein concentrations studied. In dynamic systems, the problem is even more complex because of the different rates of diffusion of proteins and mineral ions and depletion of potential inhibitors that may result when active nucleation is involved. Several variables are important in this kind of in vitro study: protein source and purity, assay system, ratio of solid to liquid used in vitro as compared with the contact surface involved in vivo, and the solution $\mathrm{pH}$, because the protein-surface interaction is driven by surface charge. ${ }^{285,286}$ However, we must remember that determining whether a protein is a nucleator, inhibitor or both of the crystalline phase (found in normal or pathological calcification) precipitation in vitro does not indicate that it has the same effect in vivo.

Regarding cations such as $\mathrm{Fe}, \mathrm{Sr}, \mathrm{Se}$ and $\mathrm{Zn}$, which are present in several essential biological metalloproteins, significant investigations have been performed to understand the mechanism of interaction of these trace elements with the surface of apatite crystals. For example, Sheha et al. reported that the mechanism of metals interacting with apatite depends intimately on the experimental conditions (i.e., $\mathrm{pH}$ and the nature of the $\mathrm{Zn}^{2+}$ species). ${ }^{287}$ 


\section{CHEMICAL ANALYSIS BY FTIR SPECTROMETRY}

FTIR spectroscopy is based on the study of molecular motion interacting with a broadband infrared source. Of note, the vibrational motions of individual chemical bonds for all molecules lie in the wavelength range $2-20 \mu \mathrm{m}$ corresponding to the wavenumber $5000-500 \mathrm{~cm}^{-1}$. FTIR spectroscopy is a vibrational spectroscopy reflecting molecular structure, so it is also sensitive to molecular environment. ${ }^{288}$ This method is able to determine the chemical composition of the sample of interest but is limited in that only molecules that exhibit vibrational modes sensitive to infrared photons are revealed.

With biological samples, the major advantages of FTIR spectroscopy is that a limited number of main features exist in the infrared spectra and that it can deal with a very small quantity of sample (milligrams). FTIR experiments were performed 40 years ago with prostatic, dental, and salivary gland calculi. ${ }^{289}$

\subsection{FTIR Spectrometry Used Routinely in the Hospital}

As underlined previously, different chemical phases are present in pathological calcifications. Spectroscopy can be used to analyze overlapping FTIR spectra thus leading to quantitation of numerous substances present in the calcifications.

Several CaPs more or less crystallized or carbonated can be encountered in pathological calcifications of various origins. Interestingly, FTIR spectroscopy is a technique allowing identification of amorphous carbonated $\mathrm{CaP}$ (ACCP), carbonated apatite (CA) and HAP (Figure 6). The different

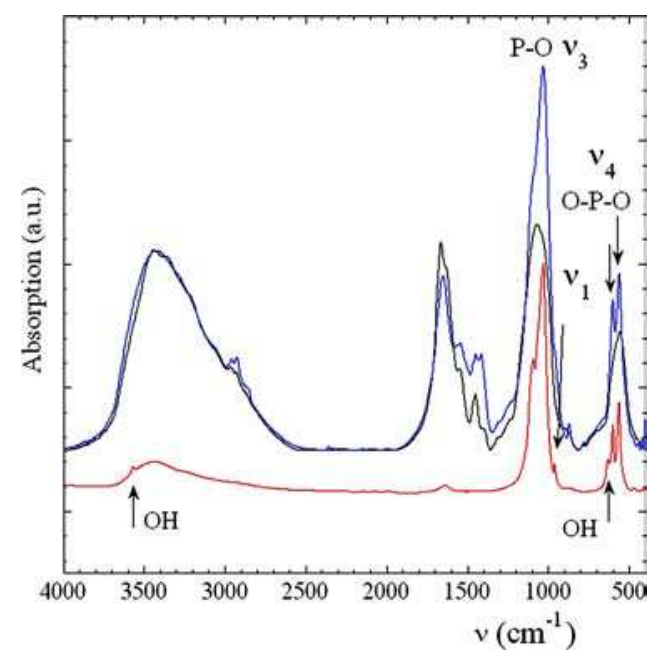

Figure 6. Fourier transform infrared absorption spectra for the compounds used here as references (hydroxyapatite [HAP], red; carbonated apatite $[\mathrm{CA}]$, blue; amorphous carbonated calcium phosphate $[\mathrm{ACCP}]$, black).

absorption bands of apatites are well assigned. The $\nu_{1}$ and $\nu_{3}$ $\mathrm{P}-\mathrm{O}$ stretching vibration modes are observed at $960-962 \mathrm{~cm}^{-1}$ and $1035-1045 \mathrm{~cm}^{-1}$, respectively, whereas the $\nu_{4} \mathrm{O}-\mathrm{P}-\mathrm{O}$ bending mode corresponds to the doublet at $602-563 \mathrm{~cm}^{-1}$. The bands at 3570 and $633 \mathrm{~cm}^{-1}$ corresponding to the stretching and vibrational modes of the $\mathrm{OH}^{-}$groups are observed for HAP and are almost absent for the biological apatites (CA) and ACCP. A key point in the analysis is linked to the presence of a shoulder in the $\nu_{3}$ absorption band, which can be used as a fingerprint for the presence of the ACCP compound. $^{290}$
Regarding kidney stones, most of them are made of calcium oxalate, but $\mathrm{CaOx}$ monohydrate and $\mathrm{CaOx}$ dihydrate must be distinguished mainly because the first is associated with hyperoxaluria and the latter is related to hypercalciuria. Even in difficult cases in which only one water molecule separates the two compounds (weddelite and whewellite), $\mathrm{CaOx}$ identification is easy by infrared spectroscopy.

\subsection{Clinical Case Characterized with Classical FTIR Spectroscopy}

From a medical viewpoint, the quantitative content of each mineral component, as well as their spatial distribution, must be determined for the medical report. Figure 7 shows a kidney stone of quite large dimension $(18 \mathrm{~mm})$ from which the spatial distribution of the chemical phases from the core to its surface gives the chronological succession of the different abnormalities. The core of the kidney stone is made of ammonium urate induced by diarrhea (Figure 7B). Then, FTIR spectroscopy reveals the presence of whewellite (Figure $7 \mathrm{C}$ ). The associated hyperoxaluria is due to vegetal alimentation and low diuresis. Finally, the surface of the kidney stone is made of a mixture of CA and weddelite related to hypercalciuria of dietetic origin (Figure 7D).

The importance of the spatial distribution of the chemical phases has been underlined in several examples. As reported by Li et al., ${ }^{291}$ the chemical composition of atheroma plaque can be accurately revealed by FTIR spectroscopy. Several characteristic bands can be observed: bands at 2930 and $2850 \mathrm{~cm}^{-1}$ indicate the presence of lipids, those at $1730 \mathrm{~cm}^{-1}$ the presence of lipid esters, peaks at 1550 and $1650 \mathrm{~cm}^{-1}$ are assigned to amide bands of proteins in fibrous tissues, and finally the broad phosphate band at $1100-1000 \mathrm{~cm}^{-1}$ indicates the presence of CaP-based calcification. In bone mineral, ${ }^{292}$ because phosphate is the most abundant anion, several works ${ }^{293}$ have involved measuring the level of mineralization, which can be estimated by the area ratio of the $\nu_{4} \mathrm{PO}_{4}\left(500-650 \mathrm{~cm}^{-1}\right)$ to that of amide I band area $\left(1600-1700 \mathrm{~cm}^{-1}\right)$ in some cases after a medical procedure such as ovariectomy. ${ }^{294}$

\subsection{Enhancing Spatial Resolution with Synchrotron Radiation (SR)}

With a conventional blackbody source, the spatial resolution is limited theoretically at a scale of several tens of square micrometers. A significant breakthrough ${ }^{295,296}$ involved the combination of a FTIR spectrometer with SR as a source ${ }^{297-301}$ and then with an optical microscope to study the distribution and characteristics of the mineral phase in calcifications at the micrometer spatial resolution (i.e., at the cell scale). Thus, as reported in different review articles, ${ }^{302-304}$ the use of FTIR spectroscopy is implemented in different SR facilities. In this configuration, FTIR spectra with exceptionally high quality (high signal-to-noise ratio) are collected from areas as small as $3 \times 3 \mu \mathrm{m}^{2}$, on as little as $10^{-9} \mathrm{~g}$ of sample.

Specific support was developed to view samples with both FTIR and X-ray microscopes (i.e., correlate the different organic/inorganic phases and trace metal composition in biological cells and tissues). ${ }^{305}$

Regarding data analysis, for many medical diagnostic problems, multivariate statistical approaches (such as principal components analysis, linear discriminant analysis) have replaced conventional spectroscopy analysis. Multivariate approaches have been used to identify pathological inclusions such as foreign matter ${ }^{306}$ and unusual soft tissue calcifications. ${ }^{307}$ In a recent review, Boskey et al. ${ }^{308}$ described the 

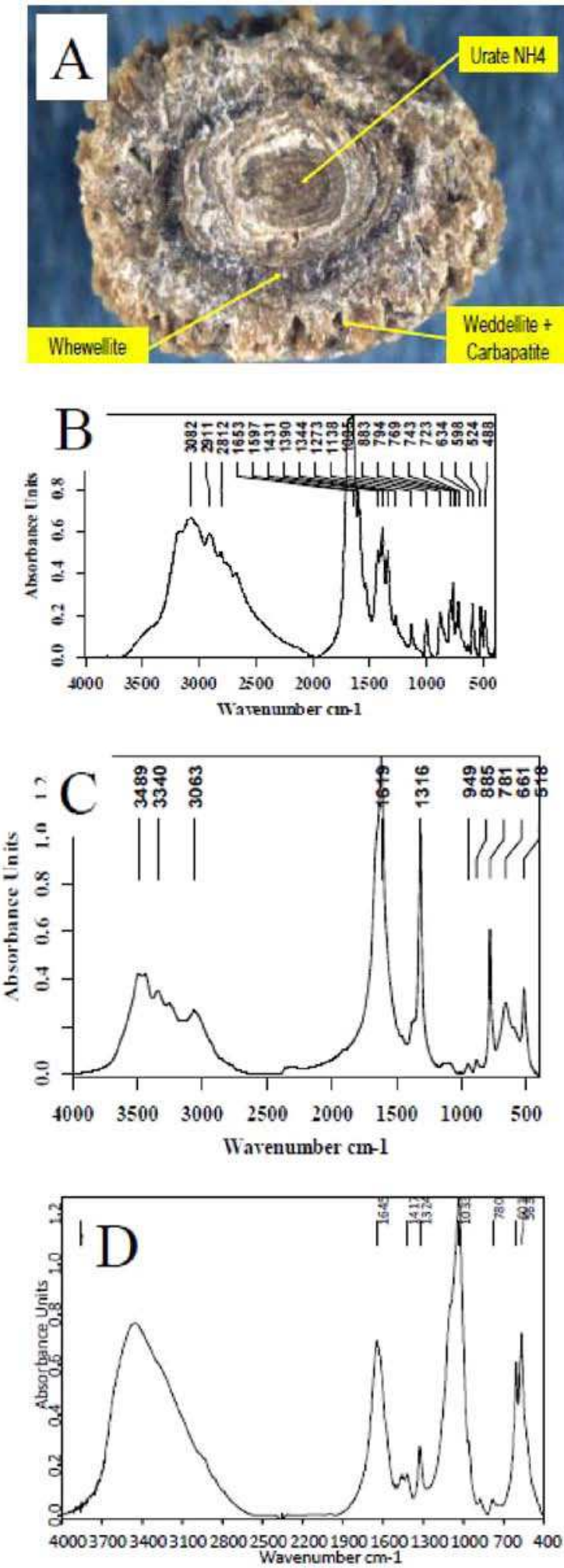

Figure 7. (A) Kidney stone from a 9-year-old child. FTIR mapping of different areas of the kidney stone: (B) ammonium urate, (C) COM, (D) CA, and COD.

advantages of FTIR microscopy in the analysis of bone and cartilage in healthy and diseased tissues. Regarding other kinds of calcification, Narasimhulu et al. ${ }^{309}$ conducted a structural study of pancreatic stones in patients with chronic pancreatitis. XRD diagrams revealed the presence of calcium carbonate stones, whereas the FTIR spectra reveal the presence of many organic bands corresponding to the amide groups in proteins. Also, calculi analysis ${ }^{310,311}$ with physical methods such as FTIR spectroscopy or X-ray diffraction can demonstrate the presence of the drug or its metabolites inside calculi. In calculi due to the metabolic effects of a drug, diagnosis relies on both stone analysis and clinical inquiry. Toscano et al. ${ }^{312}$ used FTIR spectroscopy to measure the chemical composition of gallstones and found the presence of cholesterol as the main chemical component. Also, Mattson et al. performed a chemical analysis of articular calcium containing crystals by SR-FTIR spectroscopy.$^{313}$

Finally, by performing infrared mapping of selected areas of the biopsy, we were able to identify at least 2 different crystalline species in the same sample (Figure 8). ${ }^{314}$

Moreover, an optical image of a kidney biopsy shows the glomerulus containing very refringent crystals and the proximal
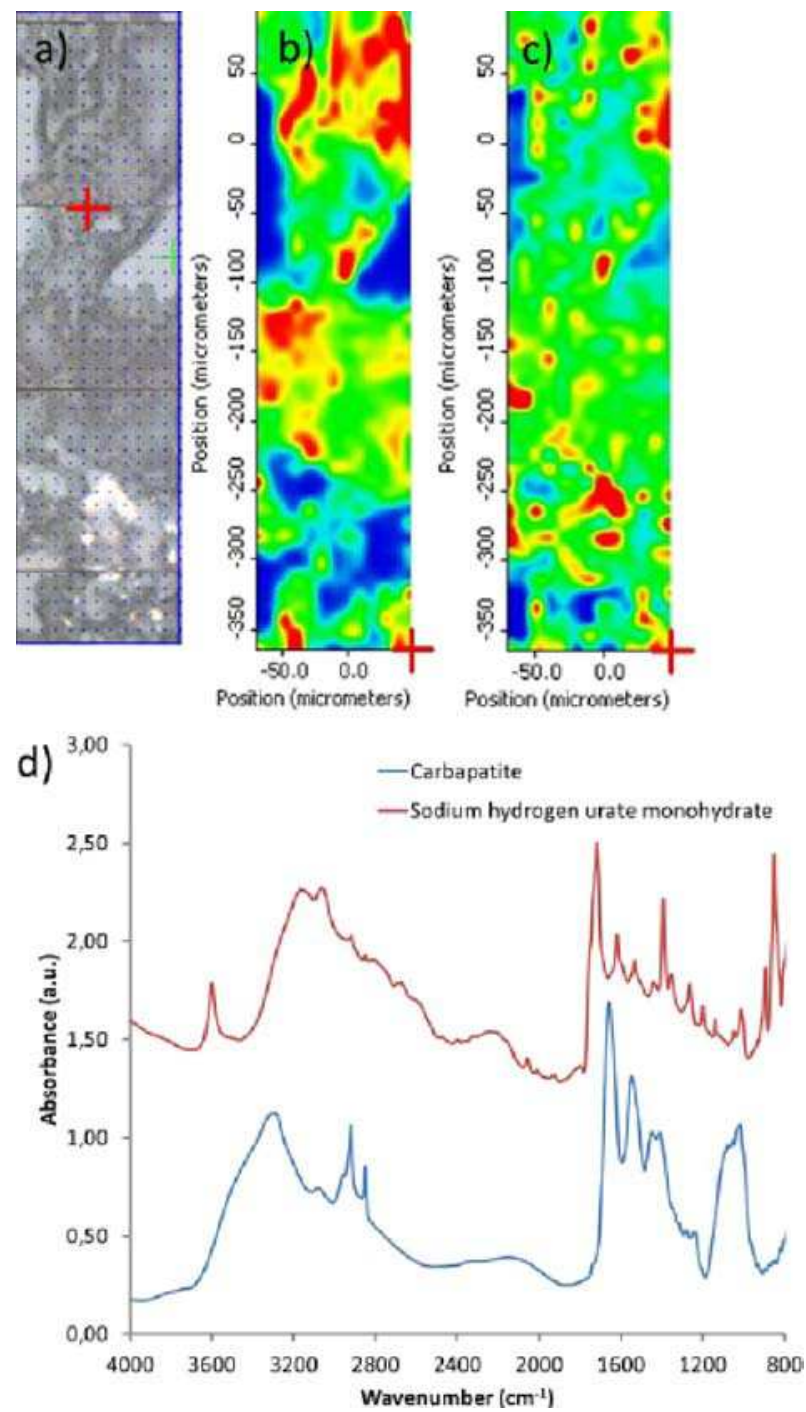

Figure 8. Optical image and mapping of an area of a kidney biopsy (scale from blue to red with the concentration increase), and FT-IR spectra of crystals. (a) Optical image of an area of a kidney biopsy (BR165 specimen), (b) carbonated apatite map (done at $1030 \mathrm{~cm}^{-1}$ ), (c) sodium hydrogen urate monohydrate map (done at $3600 \mathrm{~cm}^{-1}$ ), and (d) FT-IR spectra of these two compounds. Reprinted with permission from ref 314. Copyright 2007 Public Library of Science. 
tubules close to the glomerulus, in which pathological deposits were also observed (Figure 9a). The small size of the probe

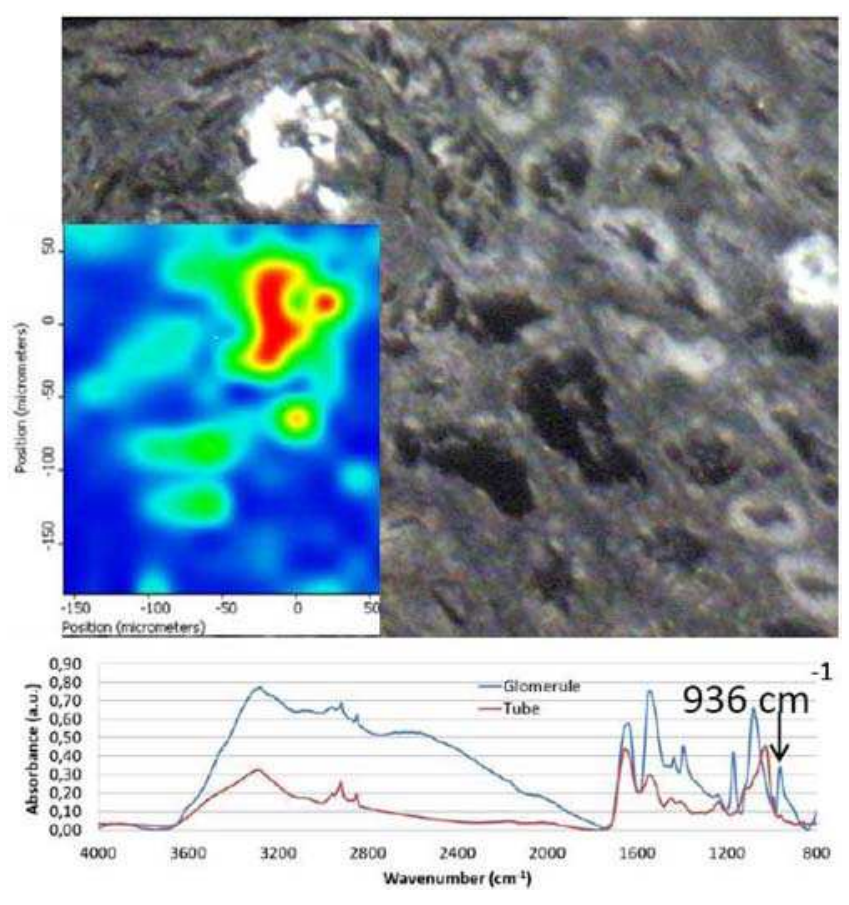

Figure 9. Mapping and optical image of a birefringent structure in kidney biopsy. The poorly soluble foscarnet can be detected and quantified after a mapping of the biopsy thanks to the characteristic peak at $936 \mathrm{~cm}^{-1}$. Reprinted with permission from ref 314 . Copyright 2007 Public Library of Science.

allowed us to characterize separately the phases deposited in the glomerulus and in the wall of the tubules. The crystals agglomerated in the glomerulus were identified as sodium foscarnet (Figure 9b). In contrast, deposits within the cells of the proximal tubules were made of apatite (Figure 9c).

\subsection{Other Major Applications of FTIR Spectroscopy in Medical Science}

Through SR-FTIR spectroscopy, at least two groups have done outstanding work on chemical imaging. Le Naour et al. ${ }^{242}$ demonstrated from liver biopsies that bands linked to lipid contribution such as $-\mathrm{CH}_{3}$ and $-\mathrm{CH}_{2}$, as well as esters, were highly intense in steatotic vesicles. Moreover, a careful analysis of the $-\mathrm{CH}_{2}$ symmetric and antisymmetric stretching modes revealed a slight downward shift in spectra inside steatotic vesicles as compared with spectra outside the vesicles, which suggests a different lipid environment inside the steatotic vesicles. Sulé-Suso et al. ${ }^{315-318}$ used both SR-FTIR and Raman spectroscopy to assess possible differences between human pluripotent (embryonic) and multipotent (adult mesenchymal) stem cells and how $\mathrm{O}_{2}$ concentration in cell culture could affect the spectral signatures of these cells. This work shows that FTIR spectroscopy of embryonic and adult mesenchymal stem cells have different spectral signatures based on the amount of lipids in their cytoplasm (confirmed by cytological staining). Furthermore, culture conditions such as $\mathrm{O}_{2}$ concentration can affect the biochemical make up of some of these cells. Moreover, note that several investigations regarding different kinds of cancer have been performed recently through Raman spectroscopies. $^{319-326}$

\section{WIDE- AND SMALL-ANGLE X-RAY AND NEUTRON SCATTERING}

$\mathrm{X}$-ray and neutron scattering techniques have emerged as some of the most powerful tools in materials science. The parallel developments in materials science and neutron and SR science worldwide have been particularly rapid. Most of our knowledge of structure of materials has been obtained by those techniques. Many books and several review articles are dedicated to the fundamental aspects of these techniques. ${ }^{327,328}$ Diffraction techniques can be used to determine the crystal structure 329,330 or the chemical composition of the calcification with the powder diffraction standards database, ${ }^{331}$ which contains more than 64000 patterns, including 12000 of metals and alloys.

Here we highlight some complementary aspects with FTIR spectroscopy. For example, diffraction techniques are quite insensitive to unorganized organic parts of samples but give some essential information regarding the size, morphologic features, and orientation of the nanocrystals ${ }^{332,333}$ of the mineral part. As noted by Sperrin et al., ${ }^{334}$ these factors are important when trying to elucidate the mechanism for in vivo crystal growth. More precisely, we can estimate the crystallite size from the broadening of the peaks by means of the Scherrer equation (after correction for instrumental broadening with a silicon standard) assuming negligible microstrain broadening. ${ }^{335}$ In fact, if the crystallite size broadening is generally considered independent of the order of reflections (e.g., 001, 002,004 , etc.), the effect of microstrain depends on two theta $(2 \theta)$ and therefore on the order of reflection. ${ }^{336}$ Note that special attention has been paid to the analysis procedure, and several works have been dedicated to the case of biomaterials. $^{337}$

\subsection{Considering Neutron and X-ray Scattering Techniques}

Neutrons as a probe at the atomic scale provide another set of nondestructive investigation techniques. Their complementarity with SR may be illustrated by two physical parameters related to the fraction of the sample analyzed and to the amplitude of the interaction between the probe and the matter. The first parameter is the penetration depth of the probe and the second is the atomic diffusion factor.

Since neutrons are electrically neutral, they interact only weakly with matter into which they can penetrate deeply. Thus, powder neutron diffraction (PND) provides structural information. PND thus allows for establishing an intimate relationship between the average size of the nanocrystals of kidney stone and its morphologic features at the macroscopic scale. In addition, SR diffraction takes advantage of its short penetration depth (about $20 \mu \mathrm{m}$ for X-ray photons corresponding to $\lambda=0.1 \mathrm{~nm}$ ), as well as the small size of the beam to establish a structural high resolution mapping of the biological entity at the micrometer scale.

The second parameter, the atomic diffusion factor, explains why the differences in positional parameters for heavy atoms are marginal but can be significant for light atoms, especially for hydrogen. ${ }^{338}$ Thus, in some cases, using neutron scattering rather than X-ray scattering is more appropriate. ${ }^{339}$ Another interesting application of neutron beams is inelastic neutron scattering (INS). For example, Loong et al. ${ }^{340}$ discussed hydroxyl-ion deficiency in apatite using INS.

Regarding the study of physiological abnormalities of bones, we can obtain information on the orientation of the nanocrystals, this parameter being linked to mechanical properties. Bacon and Goodship ${ }^{341}$ showed through neutron 
diffraction that the long bones of animals have the $c$ axes of their apatite crystals preferentially oriented to withstand stresses.

\subsection{Determining Nanocrystal Structural Parameters}

For biological apatites, the crystals are nanometer-sized, with an average length of $50 \mathrm{~nm}, 25 \mathrm{~nm}$ wide, and 2-5 nm thick, scattered in the organic matrix. This nanostructure with a high anisotropy is observed in a large number of biological apatites, and thus an isomorph of apatite is observed whatever its origin. ${ }^{342}$ Diffraction diagrams of different calcifications made of carbonated apatite, cystine, whewellite and struvite are presented in Figure 10A. The diffraction peaks of CA based
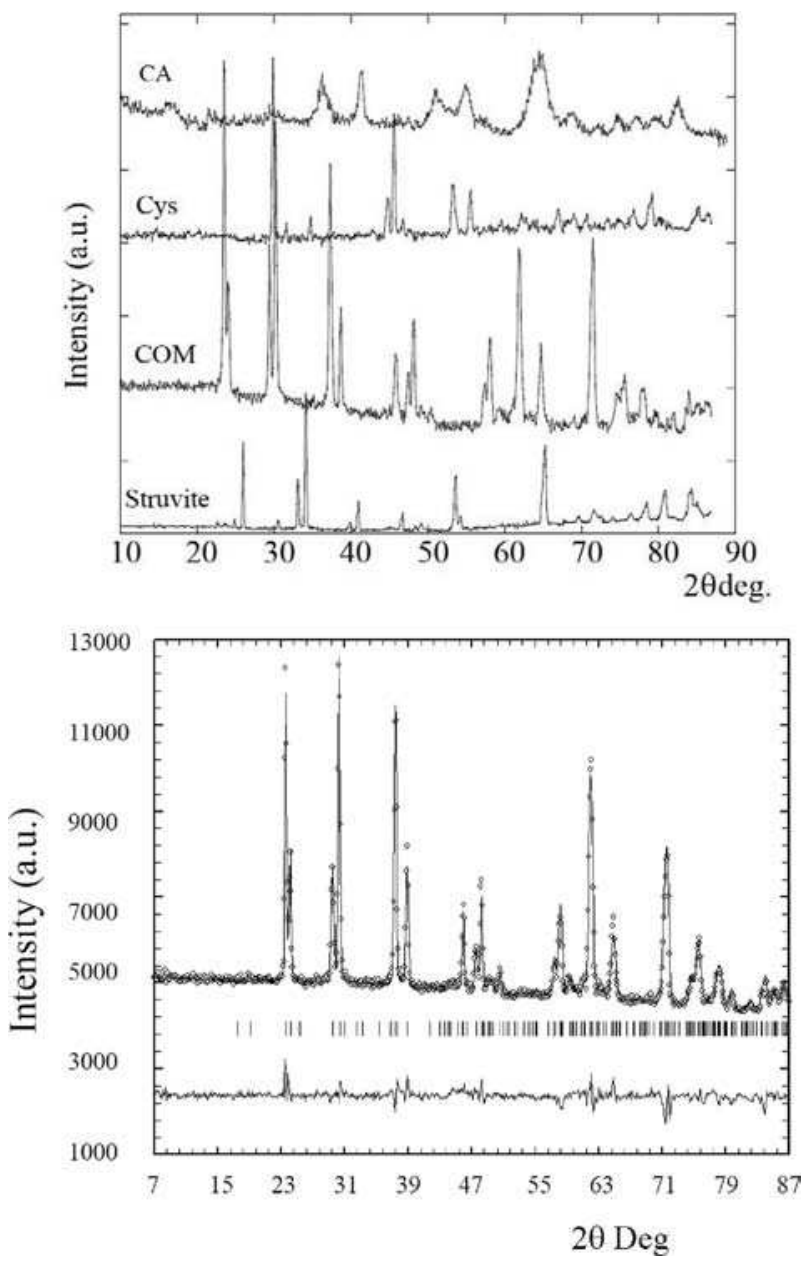

Figure 10. (A) Neutron scattering diagrams of different calcifications made of carbonated apatite (CA), cystine (Cys), whewellite (COM), and struvite. (B) Rietveld refinement analysis, with experimental $(\mathrm{O})$, calculated (-) and difference powder neutron diffraction patterns of a kidney stone sample consisting of $\mathrm{CaOx}$ monohydrate. Tick marks below the profiles indicate the peak positions of allowed Bragg reflections for the whewellite.

calcifications are quite broad, in line with their nanometer size, but the other chemical phases (cystine, whewellite, struvite) are associated with fine diffraction peaks, which reveals that the dimension of their nanocrystals is larger. For example, in a previous investigation, we highlighted that the dimension of whewellite nanocrystals is about $100 \mathrm{~nm}^{16}$

Figure 10B shows a plot of the diffraction patterns $(300 \mathrm{~K})$ of the kidney stone. As noted previously, the initial background measured on the data is high because of the significant presence of hydrogen in biological samples. Nevertheless, the good quality of the data allows us to proceed to a complete Rietveldtype refinement analysis.

Therefore, we have a possible link between the dimension of nanocrystals and the abnormality. This opportunity is important because, as underlined previously, with pathological calcifications, the same chemical phase can be related to several abnormalities. An investigation of the polymorphism can be thus the key to understanding the physicochemistry processes associated with the disease.

\subsection{Simulations of Scattering Diagram by Debye Formulas}

The radial distribution method and the method of direct intensity calculation are rather complementary to each other. ${ }^{343}$ The radial distribution method is usually preferred to analyze scattering data, but the new generation of computers allows for performing a complete analysis by use of the Debye formulas, specifically with nanomaterials. ${ }^{344,345}$

Guagliardi et al. carried out a Debye function analysis of diffraction patterns from nanosized mineral crystals of apatite. $^{346}$ The approach provides information about crystal structure, size and shape distributions of the mineral component of the newly formed bone.

Also, the approach is able to assess the distribution of cations such as $\mathrm{Zn}^{2+}$ or $\mathrm{Sr}^{2+}$ in apatite, taking into account the variation in the atomic scattering factor with energy. Similar simulations have been performed for nanometer-scale bimetallic clusters.

\subsection{Other Data/Information from X-ray and Neutron Scattering}

Diffraction techniques offer the possibility to consider substitution processes in mineral phases found in pathological calcifications. With apatites, two main types of substitution exist. The first concerns the replacement of $\mathrm{OH}^{-}$or $\mathrm{PO}_{4}{ }^{3-}$ by $\mathrm{CO}_{3}{ }^{2-}$ and the second, replacement of $\mathrm{Ca}^{2+}$ by other cations namely, $\mathrm{Cd}^{2+}, \mathrm{Pb}^{2+}, \mathrm{Sr}^{2+}$, or $\mathrm{Zn}^{2+}$.

For example, carbonate substitution in apatites are known to change the crystal lattice parameters depending on the type of substitution; pure type-A substitution $\left(\mathrm{CO}_{3}{ }^{2-}\right.$ substitutes for $\left.\mathrm{OH}^{-}\right)$causes expansion of the $a$ - and contraction of the $c$-axis parameters. ${ }^{347} \mathrm{In}$ contrast, pure type-B substitution $\left(\mathrm{CO}_{3}{ }^{2-}\right.$ substitutes for $\left.\mathrm{PO}_{4}{ }^{3-}\right)$ causes contraction of the a- and expansion of the $c$-axis dimensions.

Regarding the replacement of $\mathrm{Ca}^{2+}$ cations, through a classical X-ray diffraction study of solid solutions $\left[\mathrm{Ca}_{10-x} \mathrm{Cd}_{x} \mathrm{HAP}(x=0-10)\right],\left[\mathrm{Ca}_{10-x} \mathrm{Sr}_{x} \mathrm{HAP}(x=0-10)\right]$, and $\left[\mathrm{Ca}_{10-x} \mathrm{~Pb}_{x} \mathrm{HAP}(x=0-10)\right]$, Zhu et al. ${ }^{348}$ found that the metal ions of $\mathrm{Pb}^{2+}, \mathrm{Sr}^{2+}$, and $\mathrm{Cd}^{2+}$ preferentially occupied $\mathrm{M}(2)$ sites in the apatite structure. Of note, in the apatite structure, the $\mathrm{Ca}^{2+}$ ions occupy two types of nonequivalent sites: ${ }^{151} \mathrm{M}(1)$ is at the 4-fold site 4(f) and $\mathrm{M}(2)$ the 6-fold site 6(h). Clearly, the nature of the occupation site of different metal ions in the apatite structure may play a significant role in the adsorption process. This result is in line with $\mathrm{M}(2)$ sites giving the directional bonding of the metal ions with hydroxyl group, and the arrangement of the staggered equilateral triangles and thus metal ions with larger ionic radius or electronegativity preferentially occupy the $\mathrm{M}(2)$ sites. Diffraction techniques allow for investigating the interface. ${ }^{349}$ For example, with human dentine, Bodier-Houllé et al. ${ }^{350}$ gave experimental evidence that conversion of OCP to HAP occurs during the growing process. 
To study the stress distribution and orientation of apatite crystals in bone by neutron scattering measurements, substantial collagen must be removed to reduce the incoherent scattering. ${ }^{351}$ Cedola et al. ${ }^{352}$ performed high-spatial-resolution small-angle X-ray scattering (SAXS) measurements using $\mathrm{SR}^{353,354}$ Small-angle scattering (SAS) of X-rays (SAXS) or neutrons (SANS) constitute powerful tools to investigate inhomogeneities in the size range from $\sim 1$ to $100 \mathrm{~nm}$.

Regarding physiological calcifications, Zizak et al. used SAXS to determine the size, shape, and orientation of the nanometersized mineral particles at the bone/cartilage interface. ${ }^{355}$ The authors noted the abrupt change of mineral particle orientation at the interface between the two tissues. Using SAXS, other authors ${ }^{356}$ considered a decalcified human femoral head section affected by osteoarthritis (OA) and showed a slight decrease in the axial periodicity between normal type I collagen and that in diseased tissue in various sites. More recently, these authors found that the established gradual reorientation of collagen fibres from orthogonal to the surface of the joint to normal to the bone-cartilage interface was heavily disrupted in $\mathrm{OA}^{357}$ Also, other authors found in more advanced lesions, with loss of cartilage, that the fibres in the calcified layer are realigned tangential to the surface. ${ }^{358}$

The team of P. Fratzl combined SAXS scanning and polarized FTIR spectroscopy ${ }^{359}$ to determine the molecular orientation of apatite and collagen components. These authors highlighted a significantly larger cancellous region than cortical region, mineralization greater in the cortex, and crystals oriented to a larger degree in the cancellous than cortical bone.

\section{X-RAY ABSORPTION SPECTROSCOPY SPECIFICALLY RELATED TO SR}

In materials science, diffraction techniques can be completed by structural investigation with X-ray absorption spectroscopy (XAS), ${ }^{360,361}$ especially with nanocrystalline, amorphous solids and biological materials. ${ }^{362-364}$ Routine use of a microbeam (typically $15 \times 15 \mu \mathrm{m}$ ) will certainly lead to new scientific breakthroughs in medical science. ${ }^{365}$ XAS incorporates the Xray absorption near edge structure (XANES) and extended Xray absorption fine structure (EXAFS) techniques. The XANES part refers to the near-edge part of the spectrum, whereas EXAFS is an oscillatory structure observed over the wide energy range of $1000 \mathrm{eV}$ in X-ray absorption spectra.

\subsection{XANES Spectroscopy for Characterizing Pathological Calcifications}

Recently, significant progresses were made in understanding the XANES, the structure on the spectra within about $30 \mathrm{eV}$ of threshold. ${ }^{366,367}$ With recent developments in algorithms and calculation speed, quantitative calculations and fits are rapidly becoming possible in XANES, especially in the soft X-ray region. ${ }^{368,369}$ Recently, a review on numerical simulation of soft $\mathrm{X}$-ray absorption spectra at the $\mathrm{L}$ edge of different elements such as $\mathrm{Zn}$ has been published. ${ }^{370}$ The technique can be used to consider the different elements inside the mineral phases itself (i.e., the $\mathrm{C} \mathrm{K}, \mathrm{P} \mathrm{L}$, and $\mathrm{Ca} \mathrm{L}$ edges as proposed by Benzarara et al. $\left.^{371}\right)$.

In a recent study, ${ }^{372-374}$ we used the XANES part of the Xray absorption spectra to evaluate the local environment of $\mathrm{Ca}$ atoms and showed the presence of ACCP or CA compounds in the papilla (Figure 11A).

Regarding the absorption spectra collected for reference compounds (ACCP and $\mathrm{CA}$ ) at the $\mathrm{Ca}$ K-edge (Figure

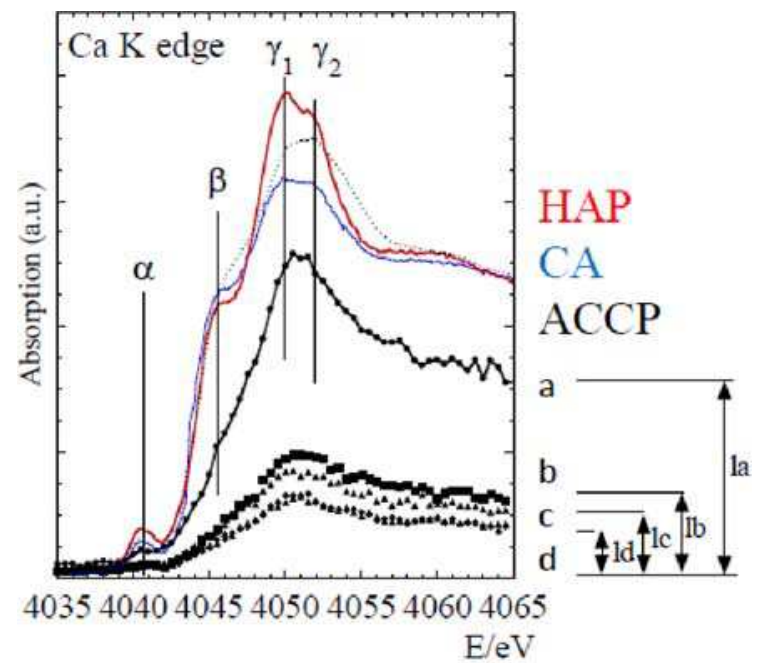

A

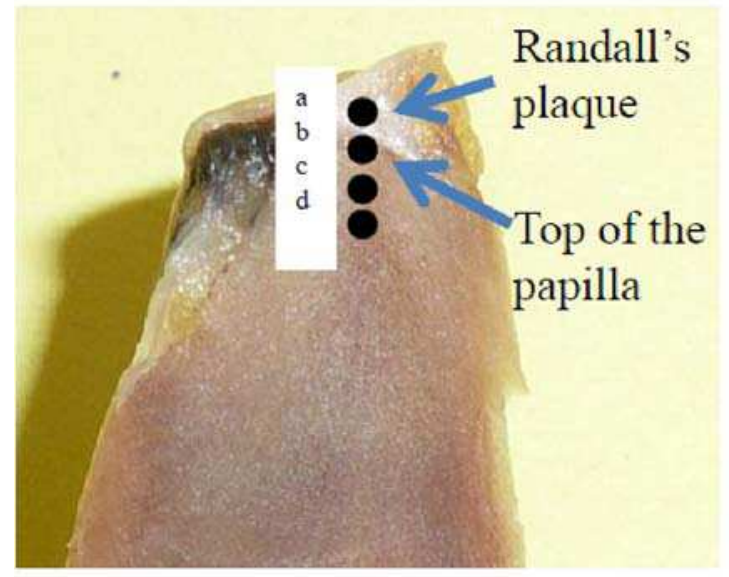

B

Figure 11. (A) X-ray absorption spectra of reference compounds (HAP, well-crystallized synthetic apatite, red; CA, biological apatite, blue; ACCP, amorphous carbonated calcium phosphate, dotted line black) and of different regions on the Randall's plaque as defined in (B). (B) Randall's plaque at the top of the papilla and details regarding positions $(a, b, c, d)$ of the beam on the sample.

11A),,$^{375,376}$ the most intense transition resonance of the spectra called the white line is observed after a prepeak $\alpha$, which can be attributed to a $1 \mathrm{~s} \rightarrow 3 \mathrm{~d}$ electron transition. Figure 11 shows that in the case of the reference $\mathrm{CaPs}$ analyzed (ACCP, CA, and HAP), the prepeak is quite similar but it is not the case for all compounds. An educational case is given with $\mathrm{TiO}_{2}$, for which the observed pre-edge features vary both in positions (by $\sim 2 \pm 0.1 \mathrm{eV}$ ) and normalized height (from $\sim 0.04$ to $1.0 \pm 0.05)$ as a function of $\mathrm{Ti}$ coordination $(4,5$, or 6 oxygen nearest neighbors). ${ }^{377-379}$

In our investigation, the white line included a shoulder-like structure (feature $\beta$ : transition $1 \mathrm{~s} \rightarrow 4 \mathrm{~s}$ ) and a double peak (features $\gamma_{1}$ and $\gamma_{2}$ : transition $1 \mathrm{~s} \rightarrow 4 \mathrm{p}$ ) whose relative intensities depend on the type of $\mathrm{Ca}$ crystallographic site involved $(\mathrm{Ca}(\mathrm{I})$ or $\mathrm{Ca}(\mathrm{II}))$.

The feature $\alpha$ is the same between the three samples HAP, CA and ACCP, but significant variations are measured for the shoulder $\beta$ and for the $\gamma_{1}-\gamma_{2}$ features. The XANES part is thus sensitive to the local order around $\mathrm{Ca}^{2+}$ cations (i.e., between the samples CA and ACCP). Of note, this type of experimental 
approach has been used for apatitic and nonapatitic CaPs of biological interest. ${ }^{380}$

We reported without normalization the different X-ray absorption spectra collected in moving from the top of the renal papilla to the medulla (Figure 11B). The amplitude (la for the spectra a) of the absorption edge (from la to ld in Figure $11 \mathrm{~A}$ ) and thus the Ca content decreases rapidly mainly because of the presence of the calcification at the top of the papilla. The feature $\alpha$ corresponds to the electronic state of calcium of $2+$ being clearly visible. The positions of the features $\beta, \gamma_{1}$ and $\gamma_{2}$, which are sensitive to the crystallinity of the calcification at the edge, are indicated. Interestingly, the shape of feature $\beta$ in papilla $1 \mathrm{a}$ is close to that of feature $\beta$ in ACCP. Moreover, the two features $\gamma_{1}-\gamma_{2}$ are not present at the top of the absorption spectra (Figure 11A, spectra a). These two observations give direct structural evidence that one of the biochemical mechanisms can be described as an agglomeration of ACCP entities in the medulla leading to the formation of Randall's plaque at the top of the papilla.

\subsection{XANES Spectroscopy for the Characterization of Trace} Elements

Trace elements can also be investigated by XAS, and results of several studies have been published recently. Among the trace elements that have been studied are $\mathrm{Fe},{ }^{381} \mathrm{Zn},{ }^{382-384} \mathrm{Sr}^{385}$ and $\mathrm{Pt}^{386-390}$

Special attention has been paid to $\mathrm{Sr}$, this element being part of medical treatment for osteoporosis. ${ }^{391-395}$ Recently, Li et al. $^{396}$ showed by XAS that $\mathrm{Sr}$ is incorporated into mineral crystals only in newly formed bone during $\mathrm{Sr}$ ranelate treatment. Unfortunately, as underlined previously, scattering techniques $^{397}$ are sensitive to $\mathrm{Sr}$ content within the mineral crystals but ignore other types of noncrystalline $\mathrm{Sr}$ deposits.

A first step in the localization of $\mathrm{Sr}^{2+}$ cations in bones of patients after medical treatment can be given by knowledge of the localization of "physiological" $\mathrm{Sr}^{2+}$ cations in pathological calcifications. In the skeleton, the total quantity of $\mathrm{Sr}$ is not insignificant, the $\mathrm{Sr} / \mathrm{Ca}$ being estimated in the human skeleton to be in the range $0.1-0.3 \mathrm{mg} / \mathrm{g}$. ${ }^{398}$

We have thus examined a set of pathological calcifications (Table 2) considering different structural hypothesis.

Table 2. Composition of Calcifications in Organs As Revealed by FTIR Spectroscopy

\begin{tabular}{|c|c|c|}
\hline sample & $\begin{array}{l}\text { origin of the } \\
\text { calcification }\end{array}$ & composition by FTIR spectroscopy \\
\hline N 11823 & kidney & $66 \% \mathrm{CA}, 30 \% \mathrm{ACCP}, 4 \%$ protein \\
\hline N 13066 & kidney & $\begin{array}{l}79 \% \text { CA, } 15 \% \text { ACCP, } 4 \% \text { protein, } 2 \% \\
\text { whewellite }\end{array}$ \\
\hline N 13086 & prostate & $84 \%$ CA, $12 \%$ protein, $4 \%$ whewellite \\
\hline N 15048 & kidney & $\begin{array}{l}87 \% \text { CA, } 6 \% \text { whewellite, } 4 \% \text { weddelite, } 3 \% \\
\text { protein }\end{array}$ \\
\hline N 17161 & bladder & $\begin{array}{l}61 \% \text { CA, } 30 \% \text { ACCP, } 8 \% \text { protein, } 1 \% \\
\text { whewellite }\end{array}$ \\
\hline
\end{tabular}

At first, $\mathrm{Sr}^{2+}$ cations are adsorbed at the surface of collagen or apatite surrounded only by oxygen atoms (hypothesis 1 in Figure 12A). Note that $\mathrm{Sr}^{2+}$ has variable coordination with oxygen and water ligands, reported from $6-12$, in solids and aqueous solutions. ${ }^{399,400} \mathrm{Sr}^{2+}$ cations can be engaged in the hydrated layer at the surface of poorly crystalline apatite nanocrystals (hypothesis 2 in Figure 12A). Finally, a substitution occurs between $\mathrm{Sr}^{2+}$ cations and $\mathrm{Ca}^{2+}$ cations
(A)
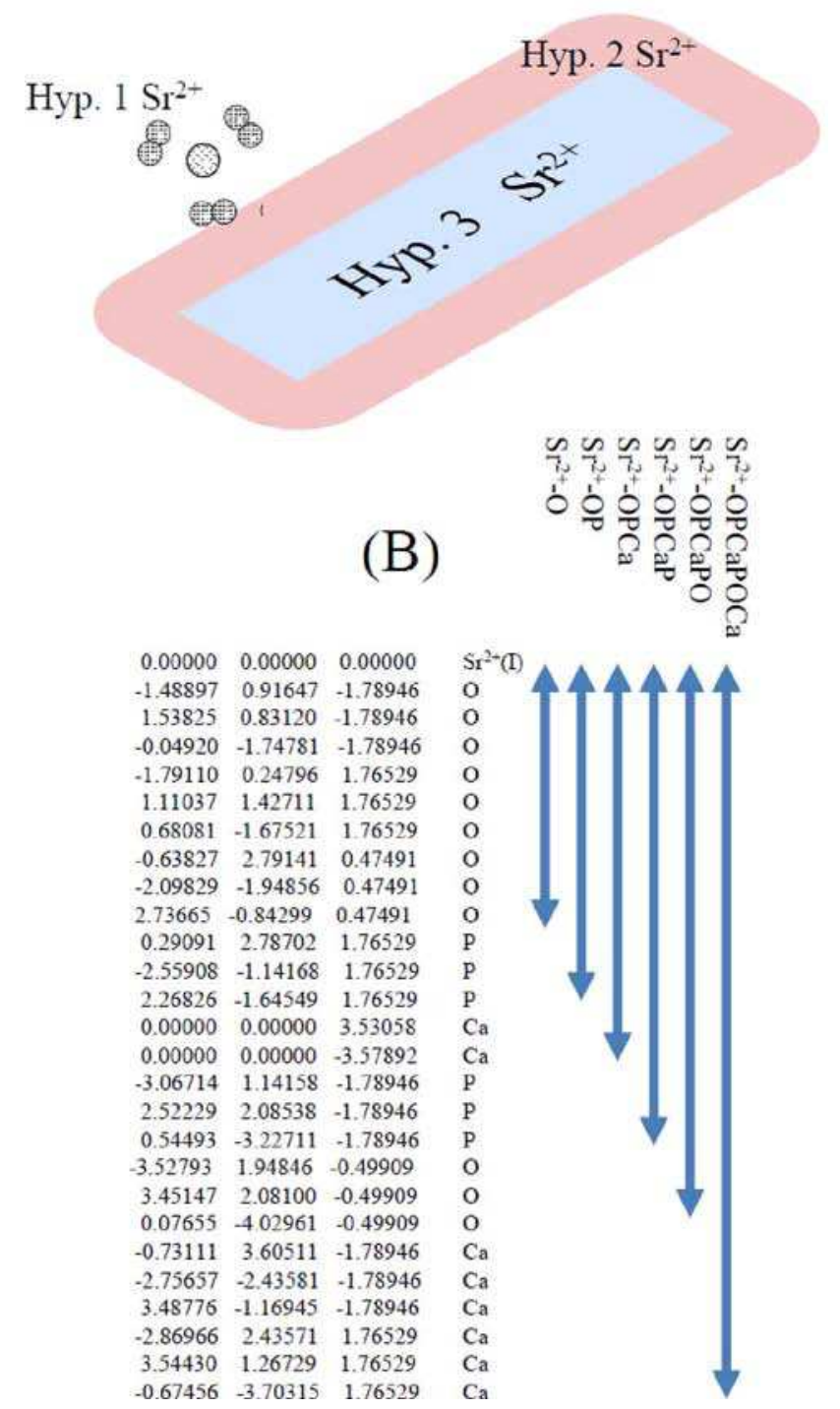

Figure 12. (A) Schematic representation of the three structural hypotheses regarding the localization of $\mathrm{Sr}^{2+}$ cations in bones. (B) Details regarding the spatial repartition of atoms around $\mathrm{Sr}^{2+}$ cations located in site (I).

inside apatite nanocrystals on crystallographic sites (I) or (II) (hypothesis 3 in Figure 12A).

As performed for $\mathrm{Zn} \mathrm{K}$ edge measurements, calculations by the FEFF program can be used to localize $\mathrm{Sr}^{2+}$ cations versus apatite nanocrystals. ${ }^{401}$

The ab initio FEFF9 code $e^{402,403}$ is quite useful to perform full multiple scattering calculations in real space for nanometer scale solids. Structural information is contained in the modulations superimposed on the otherwise smooth atomic absorption coefficient. The oscillatory structure can be expressed as a sum of independent multiple scattering contributions. Each contribution can be expressed in the following form: 


$$
\begin{aligned}
& \chi^{n}(k)=c_{0}^{n}(k) \exp \left(-L_{n} / \lambda_{n}-2 k^{2} \sigma_{n}^{2}\right) \\
& \chi_{0}^{n}(k)=F_{n}(k) \sin \left(k L_{n}+\theta_{n}(k)\right)
\end{aligned}
$$

where we have separated the oscillatory and damping terms from the mean free path and disorder. Here, $n$ represents different single or multiple scattering paths and $L_{n}$ is the total path length; $F$ and $\theta_{n}$ are the amplitude and phase which depend on the photoelectron wavenumber $k$, on the specifics of the scattering path $n$, and on the atomic potential parameters. For XANES spectra, these multiple-scattering path contributions, can also be summed to all orders by matrix inversion methods, as implemented in the full multiple scattering algorithms in FEFF9.

Here we provide different simulations to assess structural hypotheses. For the simulation labeled $\mathrm{Sr}^{2+}(\mathrm{I})-\mathrm{O}$, the local environment of $\mathrm{Sr}^{2+}$ cations is made only by oxygen atoms (details regarding the spatial repartition of oxygen atoms around $\mathrm{Sr}^{2+}$ cations are given in Figure 12B) and thus corresponds to the structural hypothesis 1 . For the simulation labeled $\mathrm{Sr}^{2+}(\mathrm{I})-\mathrm{OP}$, the local environment of $\mathrm{Sr}^{2+}$ cations is made only by $\mathrm{O}$ and $\mathrm{P}$ atoms (structural hypothesis 2, Figure 12B). For the simulations labeled $\mathrm{Sr}^{2+}(\mathrm{I})-\mathrm{OP}, \mathrm{Sr}^{2+}(\mathrm{I})-\mathrm{OPCa}$, $\mathrm{Sr}^{2+}(\mathrm{I})-\mathrm{OPCaP}, \mathrm{Sr}^{2+}(\mathrm{I})-\mathrm{OPCaPO}$, and $\mathrm{Sr}^{2+}(\mathrm{I})-\mathrm{OPCaPOCa}$, the local environment of $\mathrm{Sr}^{2+}$ cations corresponds to structural hypothesis 3 in Figure 12B.

For most of the numerical simulations, we observed only a white line at the Sr K edge followed by a simple oscillation of the absorption coefficient as we observed for experimental data (Figure 13A). This situation does not occur with simulations corresponding to $\mathrm{Sr}^{2+}(\mathrm{I})-\mathrm{OPCaPO}$ and $\mathrm{Sr}^{2+}(\mathrm{I})-\mathrm{OPCaPOCa}$ for which some structures just after the white line are observed (see arrows in Figure 13B).

These preliminary results allow for discussing the localization of $\mathrm{Sr}^{2+}$ cations in biological apatites by XANES spectroscopy. Because of the high disorder of the first coordination spheres of $\mathrm{Sr}$, simple adsorption of $\mathrm{Sr}^{2+}$ cations at the surface of apatite is related to the absence of features in the XANES part of the Xray absorption spectra. In contrast, substituting $\mathrm{Sr} / \mathrm{Ca}$ with $\mathrm{Sr}^{2+}$ cations positioned on crystallographic site (I) gives rise to XANES features.

\subsection{EXAFS Spectroscopy}

EXAFS is a powerful method for local order characterization extensively used for identifying the nature of neighboring atoms around a selected type of atom. ${ }^{404}$ This technique can be used to evaluate the interatomic distances, as well as structural and thermal disorder. EXAFS gives an average description of the local order around a selected type of atom and thus is insensitive to polydispersity. ${ }^{405}$

The data analysis procedure is simple ${ }^{406,407}$ and is based on the fact that a Fourier transform of EXAFS modulations can provide a set of peaks corresponding to the different nearestneighbor interatomic distances. EXAFS can be used to characterize different "objects" in biological and medical science. As reported in the last XAFS 13th international conference, this technique can be used to study the environment of iron in hemoproteins, ${ }^{408}$ the imaging of biological tissues, ${ }^{409}$ the characterization of $\mathrm{Zn}$ site of nonstructural protein 3 from hepatitis $\mathrm{C}$ virus, ${ }^{410}$ pharmaceutical compounds ${ }^{411}$ or the environment of copper in Wilson disease. $^{412}$ With dilute systems, a fluorescence detection technique has been developed, thus opening the possibility to

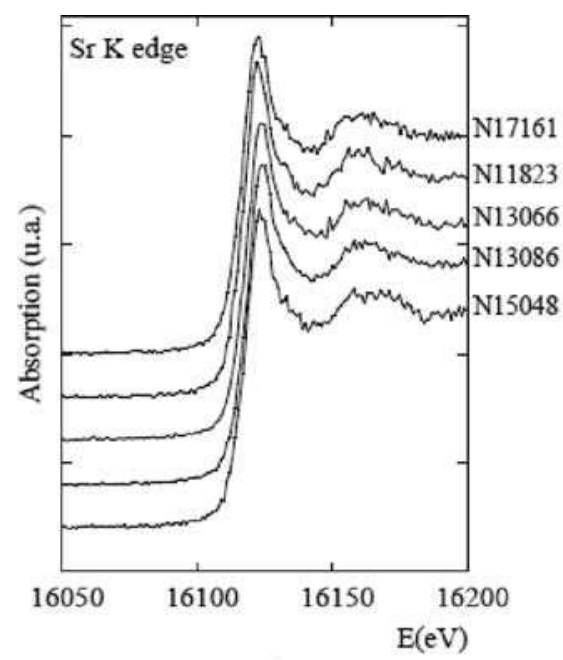

A

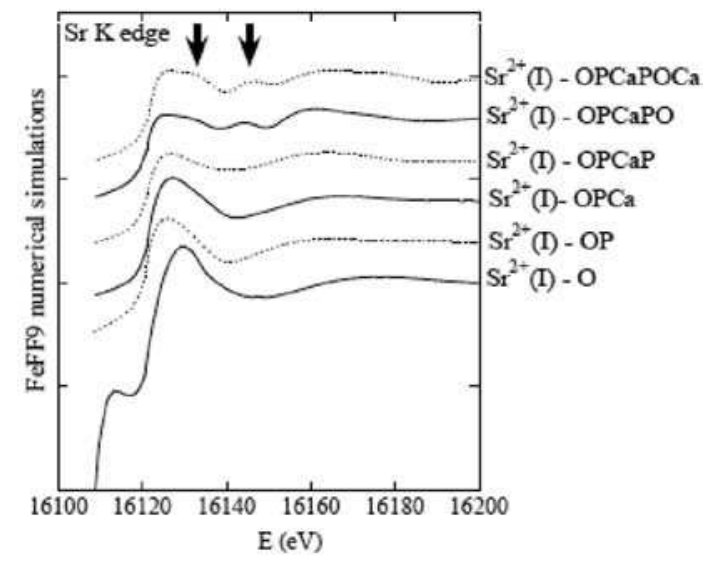

B

Figure 13. (A) XANES spectra collected at the Sr K edge for different pathological calcifications. (B) FEFF simulations for the environment of $\mathrm{Sr}^{2+}(\mathrm{I})$.

consider solution samples with a concentration less than 100$300 \mu \mathrm{M}$.

Regarding calcification, numerous publications described the environment of calcium atoms even at the early beginning of the technique, in the 1980s. ${ }^{413-415}$ For example, in the case of bone, Harries et al. ${ }^{416}$ noted that if the nearest neighborcoordination to calcium is not significantly affected by the presence of carbonate, the incorporation of carbonate into the phosphate site alters the structural geometry beyond the nearest-neighbor oxygen coordination to calcium consistent with an increase in structural disorder. Hukins et al. ${ }^{417}$ used EXAFS to characterize the phase of an amorphous calcified deposit mixed with a crystalline phase that does not contain calcium in encrusted urinary catheters. In such configuration, the amorphous phase may not be detectable by X-ray diffraction, but EXAFS reveals the presence of $\mathrm{CaP}$ deposited in association with struvite.

Holt et al. ${ }^{418}$ have considered the calcium transport by the secretory cells of the mammary epithelium: the complete set of data including EXAFS results suggest that the caseins trap the precipitate at the nucleation stage, effectively preventing a potentially disastrous first-order phase transition. 


\section{X-RAY FLUORESCENCE SPECTROSCOPY AND TRACE ELEMENTS}

$\mathrm{XRF}$ is used to determine the elemental composition of a sample by probing the electronic structure of the atoms in the sample, each element having electronic orbitals of characteristic energy. Special attention must be paid to the data analysis and specifically the absorption correction procedures for quantitative analysis. ${ }^{419,420}$ In some cases total reflection XRF that is easily qualitative for bulk analysis has to be used.

XRF has developed into a powerful tool applied to a large variety of scientific topics and is largely implemented in numerous SR photon factories. The use of such facilities has decreased the detection limits (far under ppm for most elements) and stimulated important changes in classical XRF spectrometers.

\subsection{Classical X-ray Fluorescence Spectrometry}

$\mathrm{X}$-ray fluorescence spectrometry technique has been used in several studies. For example, Ekinci et al. ${ }^{421}$ investigated human cataracts qualitatively and quantitatively by using energy dispersive X-ray fluorescence. The standard addition method was used for the determination of the concentration of $\mathrm{S}, \mathrm{Cl}, \mathrm{K}$, and $\mathrm{Ca}$. A similar approach was used to determine calcium and iodine in gall bladder stones ${ }^{422}$ and element concentrations in blood from schizophrenic, lung cancer and leukemia patients. ${ }^{423}$ Magalhães et al. analyzed 15 breasts tissue samples by X-ray fluorescence spectrometry to compare the elemental concentration in healthy and carcinoma regions of the same individual. $^{424}$

\subsection{X-ray Fluorescence Spectrometry on SR Facilities}

Thanks to the development of optics (i.e., the use of elliptical multilayer Bragg-Fresnel lenses), data with submicrometer spatial resolution can be collected with X-rays ${ }^{425,426}$ and therefore to localize the mineralization at level of the cell. ${ }^{427}$ Many studies have investigated pathological calcifications such as gallstones, urinary stones and physiological calcifications, such as teeth and bones.

Regarding gallstones, SR-XRF spectroscopy showed Ca and $\mathrm{P}$ as the major elements, and other minor elements, such as $\mathrm{Fe}$, $\mathrm{Cu}, \mathrm{Zn}, \mathrm{Se}, \mathrm{Br}, \mathrm{Sr}$, and $\mathrm{Pb}$ were also detected. ${ }^{428}$ Pal'chik et al. $^{429}$ identified the microelement composition of urinary stones. They noted that apatite urinary stones contained maximal $\mathrm{Sr}$ amounts, but struvite uroliths had higher $\mathrm{Rb}$ levels. Also, the authors highlighted that the element composition of urinary stones is a function of the mineral constituents, environmental surroundings, and specific metabolism of the patient.

Regarding physiological calcifications, Pinheiro et al. ${ }^{430}$ used an X-ray fluorescence setup with microprobe capabilities to evaluate the influence of life habits in dental elemental composition. The elemental concentration values found suggest heterogeneity of the teeth material. Moreover, the distinct profiles for $\mathrm{Mn}, \mathrm{Sr}, \mathrm{Br}$, and $\mathrm{Pb}$ were compared between teeth from a miner and a fisherman. A link was associated between dietary habits and environmental influence. Carvalho et al. ${ }^{431}$ found similar results: high levels of $\mathrm{Br}$ and $\mathrm{Sr}$ were associated with environment influence and dietary habits rich in protein, especially seafood. Also, lead is always of the order of magnitude of the detection limit, which is $1 \pm 2 \mu \mathrm{g} / \mathrm{g}$ in all analyzed teeth. Abraham et al. ${ }^{432}$ investigated dental calculus and used the atomic ratio $\mathrm{Ca}$ to $\mathrm{P}$ as an indicator of the major crystalline structure, as well as the state of formation, of the calculus.

Recently, Zhang et al. $^{433}$ determined the elemental concentrations in femoral heads from 5 autopsies and 7 patients with femoral neck fractures. Concentrations of $\mathrm{P}, \mathrm{Ca}$, $\mathrm{Fe}, \mathrm{Cu}$, and $\mathrm{Sr}$ in the control group were higher than those in the patient group, but concentrations of $\mathrm{S}, \mathrm{K}, \mathrm{Zn}$, and $\mathrm{Mn}$ did not significantly differ. In contrast, for diabetic osteoporosis, bone mineral content of $\mathrm{Ca}, \mathrm{P}, \mathrm{Zn}$, and $\mathrm{Sr}$ was decreased and relative content of $S$ increased in diabetic compared to control femurs. ${ }^{434}$

Finally, we performed a set of X-ray fluorescence experiments and found $\mathrm{Zn}$ levels greatly increased in carbonated apatite associated with $\mathrm{RP}$ as compared with carbonated apatite encountered in kidney stones, suggesting that calcified deposits within the medullar interstitium may be a pathological process involving a tissue reaction. ${ }^{435}$ Further studies, perhaps including the investigation of biomarkers for inflammation, are necessary for clarifying the role of $\mathrm{Zn}$ in $\mathrm{RP}$ formation.

\subsection{Mapping at the Micrometer Scale of Pathological Calcifications}

We investigated trace elements as risk factors of RP as a logical extension of our previous work dedicated to kidney stones. We performed X-ray fluorescence ${ }^{436,437}$ induced by protons. Particle-induced X-ray emission (PIXE) is a simultaneous trace multielement analytical technique. Depending on the proton energy and sample composition, detection limits may be as low as $\mathrm{pg} / \mathrm{g}$. Several investigations on biological samples have been based on PIXE experiments. ${ }^{438-440}$

More precisely, we examined the spatial distributions of $\mathrm{Ca}$ and $\mathrm{Zn}$ in RP by PIXE. Nuclear microprobe analyses were performed using a $2.8-\mathrm{MeV}$ proton beam at the Pierre Süe Laboratory ${ }^{441}$ and image processing using RISMIN software. ${ }^{442}$

Figure 14A represents a typical PIXE spectrum. The contributions of the different elements, namely $\mathrm{Ca}\left(E_{\mathrm{K} \alpha}=\right.$ $\left.3.692 \mathrm{KeV}, E_{\mathrm{K} \beta}=4,013 \mathrm{KeV}\right), \mathrm{Zn}\left(E_{\mathrm{K} \alpha}=8.639 \mathrm{KeV}, E_{\mathrm{K} \beta}=\right.$ $9.572 \mathrm{KeV})$, and $\mathrm{Sr}\left(E_{\mathrm{K} \alpha}=14.17 \mathrm{KeV}, E_{\mathrm{K} \beta}=15.84 \mathrm{KeV}\right)$ are well-defined. Elemental maps of $\mathrm{Ca}$ and $\mathrm{Zn}$ were generated from PIXE spectra. Each element of interest was identified by finding the integrated photopeak area associated with its $\mathrm{K}_{\alpha}$ fluorescence emission. Figures $14 \mathrm{~B}$ and $\mathrm{C}$ show examples of the elemental maps of $\mathrm{Ca}$ and $\mathrm{Zn}$ obtained at $10 \mu \mathrm{m}$ spatial resolution.

Figures $14 \mathrm{D}$ and $\mathrm{E}$ show the cartography for $\mathrm{Ca}$ and $\mathrm{Zn}$ for biopsy 2 . For biopsy 1 (Figure 14B, C), the spatial repartition of $\mathrm{Ca}$ and $\mathrm{Zn}$ differs greatly. $\mathrm{Zn}$ atoms are present at the surface of Ca domains. The reverse configuration is observed for biopsy 2 (Figure 14D, E) for which high concentration of $\mathrm{Zn}$ domains corresponds to high concentration of $\mathrm{Ca}$.

At this point, we cannot describe the local environment of $\mathrm{Zn}$ atoms. To obtain such information, similar experiments have been conducted on other family of pathological calcification through XAS experiments. From X-ray fluorescence spectra and thanks to the small size of the probe, SR XRF experimental set up offers the opportunity to establish map of different elements present in the biological sample. Recently, different investigations have been dedicated to the characterization of calcifications present in damaged cartilage tissue. $^{443,444}$ Indeed, osteoarthritis (OA) constitutes a major public health problem affecting half of the population aged over 65 years old. 

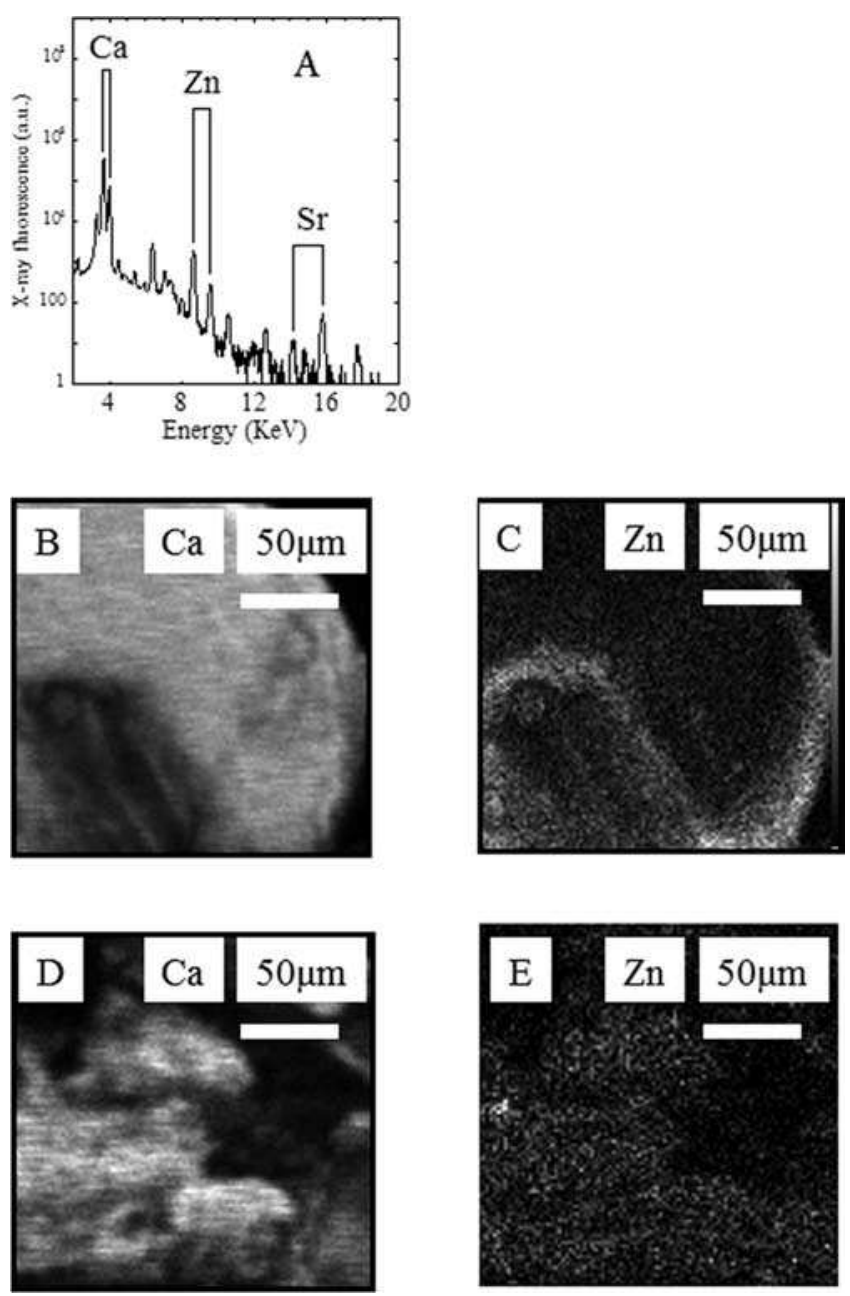

Figure 14. (A) Typical PIXE spectra collected for a Randall's plaque. (B, C) Elemental maps of RP in biopsy 1: Ca (B) and Zn (C). Darker regions indicate a higher concentration of the element (scale is 50 $\mu \mathrm{m}$ ). Total collected beam charge: $0.7 \mu \mathrm{C}$. (D and E) Elemental maps of RP in biopsy 2: $\mathrm{Ca}$ (D) and $\mathrm{Zn}$ (E). Darker regions indicate a higher concentration of the element (scale is $50 \mu \mathrm{m})$. Total collected beam charge: $0.4 \mu \mathrm{C}$.

In fact, different relationships exist between trace elements and calcifications (Figure 15). From a physicochemical viewpoint, some of these elements may induce the genesis of such crystals ${ }^{445}$ or control their morphologic features. ${ }^{446}$ From a medical viewpoint, $\mathrm{Zn}$ has antioxidant and anti-inflammatory properties. ${ }^{447}$ Of note, $\mathrm{BCP}$, or more precisely $\mathrm{CaP}$ apatite, is well-known for its capacity to trap trace elements. ${ }^{448}$ Thus, the calcification may modify the spatial distribution of $\mathrm{Zn}$ in the cartilage and thus alters the associated biological function of $\mathrm{Zn}$ metalloprotein.

XANES experiments begin by collecting classical X-ray fluorescence spectra (Figure 16A), where we can distinguish clearly the contribution of Ar present in air (experiments are performed at atmospheric pressure), $\mathrm{Ca}, \mathrm{Fe}$, and $\mathrm{Zn}$.

From these X-ray fluorescence spectra and because of the small size of the probe $(10 \mu \mathrm{m} \times 8 \mu \mathrm{m})$, mapping of the Ca $\left(K_{\alpha}\right.$ $=3691 \mathrm{eV})$ and $\mathrm{Zn}\left(K_{\alpha}=8638 \mathrm{eV}\right)$ reveals that at the mesoscopic scale, the spatial repartition of both elements is heterogeneous (Figure 16B and C). Finally, such experiments are performed on the DIFFABs beamline, so that $\mathrm{X}$-ray absorption spectra can be collected at the $\mathrm{Zn} \mathrm{K}$ edge (Figure

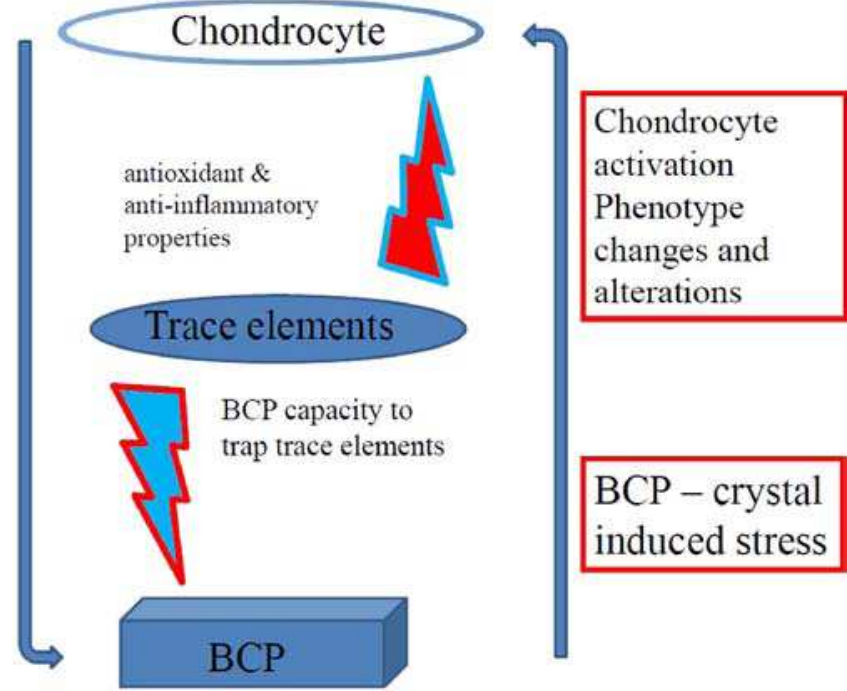

Figure 15. Simplified representation of the interaction between crystals, trace elements, and chondrocytes in cartilage.

16D) to obtain structural information on the $\mathrm{Zn}$ species present. Note that the complete set of data has not yet been published.

In section 5.4, we have cited works that highlighted the structural disorder at the cartilage-bone interface with OA. In a recent investigation, Bradley et al. noted significant modifications of the distribution maps for $\mathrm{Ca}, \mathrm{P}, \mathrm{K}$, and $\mathrm{S}$ in diseased sections at the bone-cartilage interface compared to normal tissue. ${ }^{449}$ Similar disorders were found for $\mathrm{Sr}$ and $\mathrm{Zn}$ in samples from equine metacarpophalangeal joints, around the tidemark between normal and mineralized cartilage. ${ }^{450}$

\subsection{Nature of the Trace Elements in Pathological Calcifications}

Recently, we aimed to classify the trace elements found in pathological calcifications: ${ }^{35,266}$ Class 1 elements belong to the same column of a major element of the mineral. For example, $\mathrm{Sr}$ is found in $\mathrm{CaP}$ based calcification. Class 2 elements are $\mathrm{Zn}$ or $\mathrm{Cu}$, which are implied in numerous metabolic functions. Elements such $\mathrm{Pb}, \mathrm{Cd}$, or As are the result of contamination; they can be classified in a third class of elements. In a recent study $^{23}$ dedicated to kidney stones, we found only $\mathrm{Pb}$. Of note, a highly specific accumulation of the toxic element $\mathrm{Pb}$ was recently measured in the transition zone between noncalcified and calcified normal human articular cartilage. ${ }^{451}$ In fact, a supplementary category including elements related to the administration of a drug for diagnosis or therapy can be added: among these elements are $\mathrm{Pt}^{452,453}$ and $\mathrm{I}^{454}$

\subsection{XRF at the Cellular Level}

This approach has been used for nonectopic calcifications to determine whether the abnormality induced a modification in the content or spatial repartition of trace elements in the calcification. ${ }^{455}$ The same approach can be used with tissues. In that case, special attention must be paid to the effects of radiation damage on hydrated cells. ${ }^{456}$ Palmer et al. ${ }^{457}$ described the intracellular distribution of 9 essential elements ( $\mathrm{P}, \mathrm{S}, \mathrm{Cl}, \mathrm{K}, \mathrm{Ca}, \mathrm{Mn}, \mathrm{Fe}, \mathrm{Cu}$, and $\mathrm{Zn}$ ) found in cardiomyocytes viewed by $\mathrm{SR}-\mathrm{X}$-ray induced fluorescence. Liu et al. measured the element distribution in brain sections of rats by SR-XRF. ${ }^{458}$ Yoshida et $\mathrm{al}^{459}$ studied the role of $\mathrm{Fe}$ in Parkinson's disease. $^{460-462}$ 

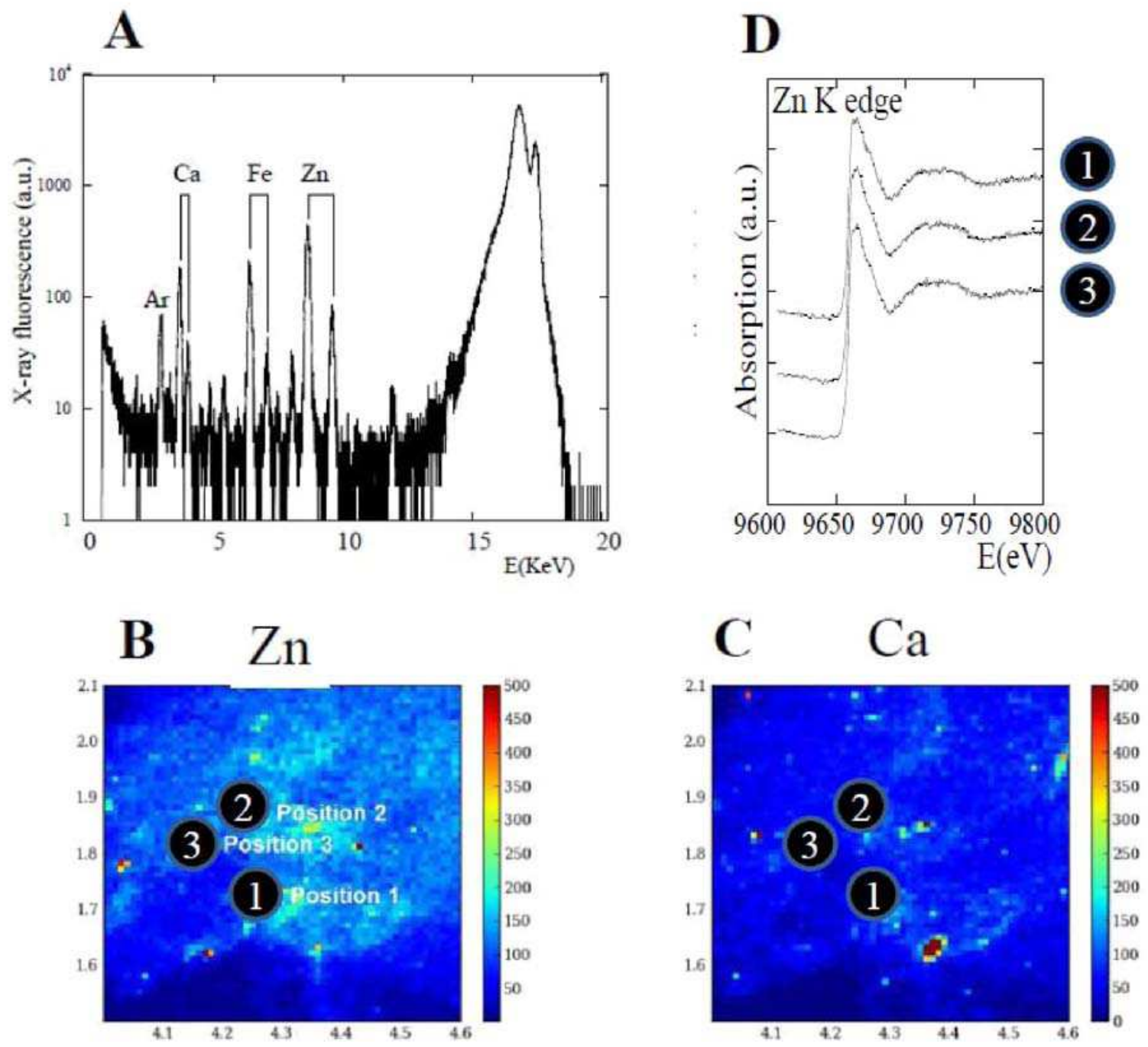

Figure 16. (A) Typical X-ray fluorescence spectrum of cartilage. We can see the contribution of $\operatorname{Ar}\left(K_{\alpha}=2958 \mathrm{eV}\right), \mathrm{Ca}\left(K_{\alpha}=3691 \mathrm{eV}, K_{\beta}=4012\right.$ $\mathrm{eV}), \mathrm{Fe}\left(\mathrm{K}_{\alpha}=6404 \mathrm{eV}, K_{\beta}=7058 \mathrm{eV}\right), \mathrm{Zn}\left(K_{\alpha}=8638 \mathrm{eV}, K_{\beta}=9572 \mathrm{eV}\right)$. (B and C) Mapping of Ca and Zn in calcified cartilage. (D) XANES spectra at the $\mathrm{Zn} \mathrm{K}$ edge.

\section{IN VIVO STUDIES}

In vivo studies are clearly the optimal experimental configuration to observe and understand the different physicochemical processes related to medical science. Such experimental geometry has been used to evaluate the presence of toxic elements in physiological calcifications.

In vivo XRF experiments ${ }^{463}$ have been performed to evaluate the concentrations of $\mathrm{Pb}$ in finger bone and $\mathrm{Cd}$ in kidney cortex. O'Meara et al. ${ }^{464}$ developed a technique to enhance the XRF renal mercury detection limit. The authors noted that despite the improved performance, detection limits remained high as compared with typical levels in exposed individuals. A similar approach was considered by Lee et al., ${ }^{465}$ who combined a $\mathrm{K}$ and $\mathrm{L}$ XRF method for the tibia bone using a system involving ${ }^{109} \mathrm{Cd}$ point source and $\mathrm{Ge}$ and $\mathrm{Si}(\mathrm{Li})$ detectors for optimum detection of the $\mathrm{K}$ and $\mathrm{L}$ X-rays, respectively. Recently, using a similar experimental set up, Nie et al. ${ }^{466-468}$ showed that the doses delivered to the organs other than the targeted lower leg were negligible and approval to conduct human measurements with this system has been received from the Research Ethics Board based on this research.
Measurements of teeth are easy and these calcifications have been considered. Zaichick et al. ${ }^{469,470}$ showed that in the case of tooth decay, the Sr content of enamel were 30\% lower than in healthy tooth. Also the authors highlighted that chronic periodontitis and especially serious forms of parodontium diseases are associated with considerable enamel demineralization. Quantitatively, contents of Ca decreased by $30 \%$ and $20 \%$, respectively, on average: Sr by $50 \%$ and $53 \%$, and $\mathrm{Zn}$ by $20 \%$ and $40 \%$. Content of $\mathrm{Pb}$ for every tooth study was found equal to or lower than the detection limit, $3 \mu \mathrm{g} / \mathrm{g}$.

In some cases, the detection of heavy elements leads to much information regarding the physicochemical mechanisms. For example, Homma-Takeda et al. showed that in proximal tubular cells, the dominant site-specific distribution of mercury appeared to be associated with induction of renal apoptosis and necrosis. $^{471}$

Finally, analysis of the phase composition of human kidney stones in model objects with the use of SR diffraction was recently published. ${ }^{472}$ Using a specific object phantom, Ancharov et al. ${ }^{473}$ explored the phase composition of kidney stones by X-ray diffraction using SR. 


\section{OTHER APPLICATIONS OF LARGE-SCALE INSTRUMENTS FOR ANALYZING CALCIFICATION IN MEDICINE}

Finally, the characterization of pathological calcifications by techniques related to SR are certainly not the only medical application. ${ }^{474,475}$ Other major opportunities exist following the pioneers works of F. Esteve, ${ }^{476-482}$ F. Peyrin, ${ }^{483-489}$ or G. Tromba. ${ }^{490,491}$ These teams have achieved several major scientific breakthroughs regarding clinical mammography, intravenous coronary angiography, or computed tomography.

Among imaging techniques, computed tomography (CT) provides exceptionally high-quality imaging of the fine structural detail within urinary calculi. ${ }^{492,493}$ One of the key advantages of this approach is its combination of exceptional details of the fine structure of human urinary stones and chemical analysis, microCT being able to differentiate six common mineral constituents.

Different developments combining imaging and chemical characterization have been performed with SR facilities. For example, X-ray transmission microtomography (CT) combined with X-ray fluorescence microtomography (XRFCT) was implemented in the Brazilian Synchrotron Light Laboratory (LNLS, Campinas, Brazil). ${ }^{494}$ With this opportunity, the concentration of some elements can be associated with characteristics and pathology of different tissues (here breast, prostate and lung tissues) observed by transmission CT.

\section{CONCLUSIONS AND PERSPECTIVES}

The societal aspect of research into pathological calcification deserves discussion. An early diagnosis of abnormalities by physicochemical techniques can reduce significantly the cost of the disease treatment. For example, we recently used SR-FTIR to identify crystals of dihydroxyadenine in a kidney biopsy from a patient with a homozygous adenine phosphoribosyltransferase deficiency, for which no diagnosis was available to explain fast progressing renal failure. ${ }^{493}$ Specific treatment resulted in improved kidney function. In such an abnormality, the absence of an accurate diagnosis and specific treatment would lead to end-stage renal failure. From an epidemiological point of view, this disease is not diagnosed throughout the world. In France, we have observed more than 60 cases, and in other countries (except Japan), about 100 cases have been identified. The same pattern is observed for primary hyperoxaluria type 1 , another genetic disease leading to end-stage renal failure. The diagnosis is based on stone morphologic features and crystal structural organization, as shown in Figure 2C. Unfortunately, few laboratories offer the opportunity to take into account stone morphologic features in addition to stone composition. As a consequence, often stones formed because of this disease are considered related to dietary disorders rather than having a genetic origin, and often the diagnosis is made after the total loss of kidney function.

From an economic point of view, the annual cost of dialysis per patient in France is about $50000 €$, and the cost of kidney replacement is also $50000 €$, with the risk of recurrence of the disease on the graft transplant without diagnosis. This cost may be compared with the annual cost of drug treatment, less than $40 €$, which is very effective. Of note, the cost of measurement using SR-FTIR is about $1000 €$.

This example could be applied to a number of pathologies, including genetic diseases, cancer, and diseases related to environmental factors and diagnosed late. Regarding medical applications, we moved from the use of very few hours on selected SR beamlines ${ }^{496-504}$ to SR facilities fully dedicated to such applications. ${ }^{505}$

Moreover, with the arrival of new generations of SR facilities (e.g., SOLEIL, Diamond, ALBA in Europe) as well as major improvements in other SR facilities in Brazil, China, Japan or South Korea, many of the above type of research topics could be extended. Indeed, the first application of SOLEIL was dedicated to the study of kidney stones. ${ }^{506}$

Right now, an SR factory can be used to perform a medical diagnosis, which is relevant in terms of rapidity and efficiency versus other techniques present in the hospital. Recently, we saved the kidney function of one patient and realized a diagnosis for more than 20 others. Similar applications were achieved with other characterizations or imaging techniques in SR facilities.

The massive gains in knowledge coupled with the fact that we can now consider different techniques for in vivo experiments means many bright prospects for investigations of pathological calcifications using large-scale instruments around the world.

\section{AUTHOR INFORMATION}

\section{Corresponding Author}

*E-mail: dominique.bazin@u-psud.fr.

Notes

The authors declare no competing financial interest.

Biographies

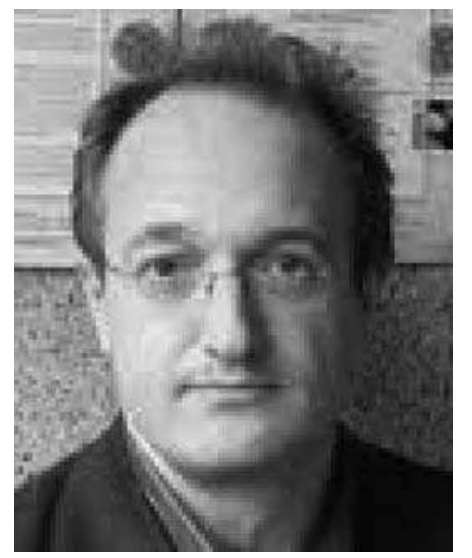

Dominique Bazin received his $\mathrm{PhD}$ in Solid State Physics at the Laboratoire pour l'Utilisation du Rayonnement Synchrotron (LURE, France) in 1985. In 1985, he obtained a position as Chargé de Recherche at Laboratoire pour l'Utilisation du Rayonnement Synchrotron (LURE, France). In 1992, he held a postdoctoral position at the Physics Department of North Caroline State University in the laboratory of Prof. D. Sayers. He is currently Research Director at the Solid State laboratory (Univeristy Paris XI) and will move to the laboratoire de Chimie de la Matière Condensée de Paris (College de France, Université Pierre et Marie Curie) at the end of 2012. His research interests include pathological calcifications as well as biomaterials. The ultimate goal of this research being an understanding of the biochemical parameters, which lead to the genesis of pathological calcifications as well as to spread physical techniques and concepts in the medical community in order to use them as diagnostic tools. 


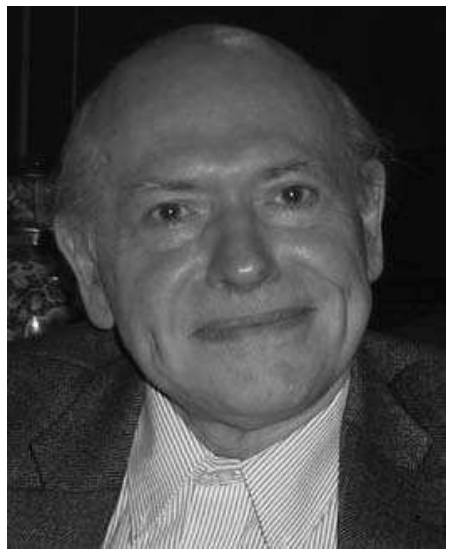

Michel Daudon is born in Bourges (France) in 1949. He was educated at the Descartes University of Paris and obtained his grade of pharmacist in 1974. Then he started research in the field of stone disease in 1975 in the new CRISTAL Laboratory (Research Center on Urolithiasis) created the same year by Jean-René Réveillaud, who has worked with Jean Hamburger, the father of nephrology. He developed stone analysis based on infrared spectroscopy and correlations between stone morphology and composition related to biochemical disorders and pathology. He proposed a new stone classification based on a morpho-constitutional approach, showing that, for a same chemical component, the different crystalline forms may orient toward various biochemical conditions and for a same crystalline phase, morphology may orient toward a specific pathology. Promoted Director of the CRISTAL Laboratory in 1986, he obtained his $\mathrm{PhD}$ grade in 1988 rewarded by the thesis prize of Biochemistry of the Paris-Sud University. He obtained the grade of Hospital Practitioner in 1990 and created a stone analysis department in Necker Hospital, now moved to Tenon Hospital in Paris (France), where all stones from surgical and medical departments of the Assistance-Publique-Hôpitaux de Paris are analyzed. Co-author of several books on nephrolithiasis, he has published more than 400 scientific papers in national and international journals. Responsible for the National Quality Control for stone analysis and crystalluria analysis, he has teached hundreds biologists and technicians for an accurate morphoconstitutional analysis of urinary calculi and more than thirty laboratories in France, Belgium, Luxemboug, Switzerland, Spain, Tunisia, Algeria and Morocco are now able to offer such analysis to physicians.

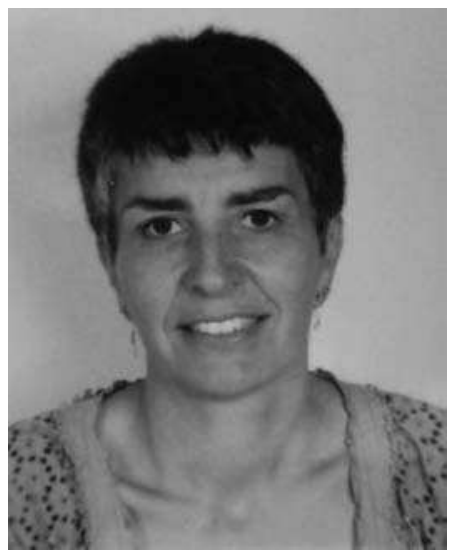

Christèle Combes received her $\mathrm{PhD}$ in Materials Science at the Institut National Polytechnique de Toulouse (INPT, France) in 1996. In 1997, she held a postdoctoral position at the Ecole Polytechnique de Montréal (Canada). In 1998, she obtained a faculty position as assistant-professor at the Ecole Nationale Supérieure des Ingénieurs en Arts Chimiques et Technologiques (ENSIACET) in Toulouse. She is currently professor at INPT- ENSIACET and she is at the head of the research group "Phosphates, Pharmacotechnics, Biomaterials" of the CIRIMAT Carnot Institute. Her research interests include biomineralizations and biomaterials.

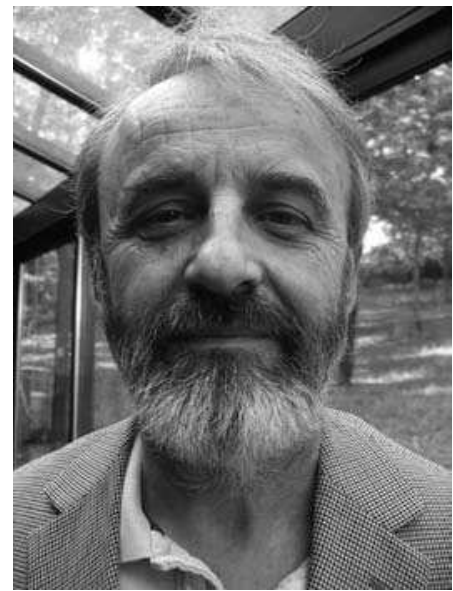

Christian Rey is Professor at INPT (Institut National Polytechnique de Toulouse). After his thesis defense in 1984 at INPT he was appointed on a postdoctoral position at Harvard University, The Children's Hospital, Dr. M. Glimcher's group (Boston, 1985-87) where he studied calcified tissues formation and aging. Coming back to Toulouse, he was appointed Professor at INPT (1987) and began to work in the field of biomaterials on continuing his collaboration with the Boston group. He was the head of the "Phospho-Chemistry of Phosphates" (PCP) team belonging to CIRIMAT (Centre Interuniversitaire de Recherche et d'Ingénieries des Matériaux) from 1993 to 2007. Christian Rey has worked essentially on biomimetic biomaterials and on biological calcium phosphates (bone and teeth). He is more specifically involved in the synthesis, the characterisation and the study of properties of nanocrystalline apatite and calcium phosphates.

\section{ACKNOWLEDGMENTS}

We thank Dr. I. Brocheriou (Necker Hospital), Dr. X. Carpentier (Nice Hospital), Dr. Ch. Chappard (Lariboisière Hospital), Prof. P. Conort (Lapitié Salpétrière Hospital), Dr. P. Dorfmüller (Lapitié Salpétrière Hospital), Prof. D. Hannouche (Lariboisière Hospital), Dr. J.P. Haymann (Tenon Hospital), Prof. P. Jungers (Necker Hospital), Prof. B. Knebelman (Necker Hospital), Dr. E.A. Korng (Lariboisière Hospital), Dr. E. Letavernier (Tenon Hospital), Prof. F. Lioté (Lariboisière Hospital), Prof. M. Mathonnet (Limoges Hospital), Prof. P. Meria (St Louis Hospital), Dr. Ch. Nguyen (Lariboisière Hospital), Dr. J. Rodes (Tenon Hospital), Dr. I. Tostivint (Lapitié Salpétrière Hospital), Prof. O. Traxer (Tenon Hospital), and Prof. J.C. Williams (Department of Anatomy and Cell Biology, Indiana University School of Medicine, Indianapolis, Indiana, U.S.A.) for providing samples and useful discussions. Also, regarding the physicochemistry, this research could not have been performed without the scientific advice of Dr. P.-A. Albouy (LPS), Dr. G. André (LLB), Dr. A. Bianchi (INSERM-U7561), Dr. P. Chevallier (LURE), Dr. A. Cousson (LLB), Dr. P. Dumas (Soleil Synchrotron), Dr. B. Fayard (LPS), Dr. F. Fayon (CEHMTI), Dr. E. Foy (Laboratoire Pierre Süe), Dr. J. Guicheux (Laboratoire d'Ingénierie Ostéo-Articulaire et dentaire), Dr. J.L. Hazemann (ESRF), Dr. A. Lebail (Laboratoire des fluorures), Dr. F. Lenaour (Hôpital Paul Brousse), Dr. O. 
Mathon (ESRF), Dr. G. Matzen (CEHMTI), Dr. Ch. Mocutta (Soleil Synchrotron), Dr. P. Reboul, (UMR 7561), Dr. M. Refringiers (Soleil Synchrotron), Dr. S. Reguer (Soleil Synchrotron), Dr. S. Rouzière (LPS), Dr. J.P. Samama (Soleil Synchrotron), Dr. Ch. Sandt (Soleil Synchrotron), Dr. D. Thiaudière (Soleil Synchrotron), Dr. E. Véron (CEHMTI) and Dr. R. Weil (LPS). This work was supported by the Physics and Chemistry Institutes of CNRS and by contract ANR-09-BLAN0120-02. The authors are grateful to the Soleil SR Facility and the Leon Brillouin laboratory for beam time allocation.

\section{REFERENCES}

(1) Biomineralisation: Chemical and Biochemical Perspectives; Mann, S., Webb, J., Williams, R. J. P., Ed.; VCH Verlag: Weinheim, Germany, 1990.

(2) Lindroos, M.; Kupari, M.; Heikkila, J.; Tilvis, R. J. Am. Coll. Cardiol. 1993, 21, 1220.

(3) Nouvelles méthodes d'étude des calculs et plaques de Randall. In Actualités Nephrologiques-Jean Hamburger Médecine-Sciences Bazin, D.; Daudon, M., Eds.; Flammarion: Paris, 2010; pp 75-98.

(4) Schmidt, F.; Sorantin, E.; Szepesvari, C.; Graif, E.; Becker, M.; Mayer, H.; Hartwagner, K. Phys. Med. Biol. 1999, 44, 1231.

(5) Moon, W. K.; Im, J. G.; Koh, Y. H.; Noh, D. Y.; Park, I. A. Radiology 2000, 217, 849.

(6) Winston, J. S.; Yeh, I. T.; Evers, K.; Friedman, A. K. Am J Clin Pathol. 1993, 5, 488.

(7) Haka, A.; Shafer-Pettier, K. E.; Fitzmaurice, M.; Crowe, J.; Dasari, R. R.; Feld, M. Cancer Res. 2002, 62, 5375.

(8) Baker, R.; Rogers, K. D.; Shepherd, N.; Stone, N. Br. J. Cancer 2010, 1.

(9) Liu, C.; Zhang, Y.; Yana, X.; Zhang, X.; Lid, C.; Yang, W.; Shi, D. J. Lumin. 2005, 119-120, 132.

(10) Sattlecker, M.; Baker, R.; Stone, N.; Bessant, C. Chemom. Intell. Lab. Syst. 2011, 107, 363.

(11) Bonucci, E. Biological Calcification, Normal and Pathological Processes in the Early Stages; Springer Verlag; Berlin, 2007.

(12) Biomineralization-Medical Aspects of Solubility; Königsberger, E., Königsberger, L. C., Ed. Wiley Interscience: New York, 2006.

(13) Coe, F. L.; Evan, A.; Worcester, E. J. Clin. Invest. 2005, 115, 2598

(14) Daudon, M; Doré, J. C.; Jungers, P; Lacour, B. Urol. Res. 2004, 32, 241.

(15) Grases, F.; Costa-Bauza, A.; Gomila, I.; Ramis, M.; Garcia-Raja, A.; Prieto, R. M. Urol. Res. 2011, 40, 41.

(16) Williams, J. C. BJU Int. 2009, 104, 8.

(17) Cotran, R. S., Kumare, V, Robbins, S. L.: Cellular injury and cellular death. Pathological Basis of Disease, 5th ed.; Robbins, S. L., Ed.; Saunders WB: Philadelphia, PA, 1994, pp 1-35.

(18) Lowenstam, H. A.; Weiner, S. On Biomineralization; Oxford University Press: Oxford, U.K., 1989.

(19) Mann, S. Biomimetic Materials Chemistry; VCH: New York, 1996

(20) Anghileri, L. J. Calcif. Tissue Int. 1992, 51, 83.

(21) Giachelli, C. M. Am. J. Pathol. 1999, 154, 671.

(22) Ea, H. K.; Nguyen, Ch.; Bazin, D.; Bianchi, A.; Guicheux, J.; Reboul, P.; Daudon, M.; Lioté, F. Arthritis Rheum. 2011, 63, 10.

(23) Daudon, M.; Bader, C. A.; Jungers, P. Scanning Microsc. 1993, 7, 1081

(24) Daudon, M.; Jungers, P.; Bazin, D. Renal Stone Dis. 2 2008, 1049, 199.

(25) Daudon, M.; Bazin, D.; André, G.; Cousson, A.; Chevallier, P.; Véron, E.; Matzen, G. J. Appl. Crystallogr. 2009, 42, 109.

(26) Daudon, M.; Jungers, P.; Bazin, D. New Engl. J. Med. 2008, 359, 100.

(27) Van Meerssche, M. ; Feneau-Dupont, J. Introduction à la Cristallographie et à la Chimie Structurale; Vander: Louvain-Cesson, Belgium, 1973.
(28) Schoppet, M.; Al-Fakhri, N.; Franke, F. E.; Katz, N.; Barth, P. J.; Maisch, B.; Preissner, K. T.; Hofbauer, L. T. J. Clin. Endocrinol. Metab. 2004, 89, 4104.

(29) Cazalbou, S.; Eichert, D.; Drouet, C.; Combes, C.; Rey, C. C. $R$. Palevol. 2004, 3, 563.

(30) Wang, L.; Guan, X.; Du, C.; Moradian-Oldak, J.; Nancollas, G. H. J. Phys. Chem. C. 2007, 111, 6398.

(31) Seeman, N. C.; Belcher, A. M. Proc. Natl. Acad. Sci. U.S.A. 2002, 99, 6452.

(32) Zamiri, A.; De, S. J. Mech. Behav. Biomed. Mat. 2011, 4, 146.

(33) Paine, M. L.; Snead, M. L. J. Bone Miner. Res 1996, 12, 221.

(34) Ryall, R. L. World J. Urol. 1997, 15, 155.

(35) Bazin, D.; Chevallier, P .; Matzen, G.; Jungers, P.; Daudon, M. Urol. Res. 2007, 35, 179.

(36) Slojewski, M.; Czerny, B.; Safranow, K.; Jakubowska, K.; Olszewska, M.; Pawlik, A.; Golab, A.; Drozdzik, M.; Chlubek, D.; Sikorski, A. Biol. Trace Elem. Res. 2010, 137, 301.

(37) Gomes, S.; Nedelec, J. M.; Jallot, E.; Sheptyakov, D.; Renaudin, G. Chem. Rev. 2011, 23, 3072.

(38) Durak, I.; Kilic, Z.; Sahin, A.; Akpoyraz, M. Urol. Res. 1992, 20, 23

(39) Perk, H; Ahmet Serel, T.; Kosar, A.; Deniz, N.; Sayin, A. Urol. Int. 2002, 68, 286.

(40) Garban, Z.; Avacovici, A. E.; Garban, G.; Peter, F.; Ghibu, G. D.; Botoca, M.; Cumpanas, A. Stud. Univ. Babes-Bolyai, Chem. 2010, 55, 103.

(41) Slojewski, M.; Czerny, B.; Safranow, K.; Drozdzik, M.; Pawlik, A.; Jakubowska, K.; Olszewska, M .; Golab, A.; Byra, E.; Chlubek, D.; Sikorski, A. Urol. Res. 2009, 37, 317.

(42) Grases, F.; Genestar, C.; Mill, A. J. Cryst. Growth 1989, 94, 507.

(43) Ozgurtas, T.; Yakut, G.; Gulec, M.; Serdar, M.; Kutluay, T. Urol Int 2004, 72, 233.

(44) Touryan, L. A.; Lochhead, M. J.; Marquardt, B. J.; Vogel, V. Nat. Mater. 2004, 3, 239.

(45) Durak, I.; Kilic, Z.; Perk, H.; Sahin, A.; Yurtarslani, Y.; Yasar, A.; Küpeli, S.; Akpoyraz, M. Eur. Urol. 1990, 17, 243.

(46) Meyer, J. L.; Thomas, W. C., Jr. J. Urol. 1982, 128, 1376.

(47) Atakan, I. H.; Kaplan, M.; Seren, G.; Aktoz, T.; Gül, H.; Inci, O. Int. Urol. Nephrol. 2007, 39, 351.

(48) Cifuentes Delatte, L.; Santos, M. Eur. Urol. 1977, 3, 96.

(49) Carpentier, X.; Daudon, M.; Traxer, O.; Jungers, P.; Mazouyes, A.; Matzen, G.; Véron, E.; Bazin, D. Urology 2009, 73, 968.

(50) Bazin, D.; André, G.; Weil, R.; Matzen, G.; Véron, E.; Carpentier, X.; Daudon, M. Urology 2012, 79, 786.

(51) Bigi, A.; Falini, G.; Foresti, E.; Gazzano, M.; Ripamonti, A.; Roveri, N. Acta Crystallogr. B 1996, 52, 87.

(52) Meneghini, C.; Dalconi, M. C.; Nuzzo, S.; Mobillio, S.; Wenk, R. H. J. Biophys 2003, 84, 2021.

(53) Cuisinier, F. J. G.; Steuer, P.; Voegel, J.-C.; Apfelbaum, F.; Mayer, I. J. Mater. Sci. Mater. Med. 1995, 6, 85.

(54) Yu, Q.; Takeda, T.; Umetani, K.; Ueno, E.; Itai, Y.; Hiranaka, Y.; Akatsuka, T. J. Synchrotron Radiat. 1999, 6, 1148.

(55) Harvey, C. J.; Blomley, M. J. K. Surgery 2005, 23, 158.

(56) Bayat, S.; Apostol, L.; Boller, E.; Brochard, T.; Peyron, F. Nucl. Instrum. Methods Phys. Res., Sect. A 2005, 548, 247.

(57) Sone, T.; Tamada, T.; Jo, Y.; Miyoshi, H.; Fukunaga, M. Bone 2004, 35, 434

(58) Abrami, A.; Arfelli, F.; Barroso, R. C.; Bergamaschi, A.; Billè, F.; Bregante, P.; Brizzi, F.; Casarina, K.; Castelli, E.; Chenda, V.; Dalla Palma, L.; Dreossi, D.; Fava, C.; Longo, R.; Mancini, L.; Menka, R.-H.; Montanaria, F.; Olivo, A.; Pani, S.; Pillon, A.; Quai, E.; Ren Kaiser, S.; Rigon, L.; Rokvic, T.; Tonutti, M.; Tromba, G.; Vascotto, A.; Venanzi, C.; Zanconati, F.; Zanetti, A.; Zanini, F. Nucl. Instrum. Methods Phys. Res., Sect. A 2005, 548, 221.

(59) Rosenthal, A. K.; Mattson, E.; Gohr, C. M.; Hirschmugl, C. J. Osteoarthritis Cartilage 2008, 16, 1395.

(60) Bonewald, L. F.; Harris, S. E.; Rosser, J.; Dallas, M. R.; Dallas, S. L.; Camacho, N. P.; Boyan, B.; Boskey, A. Calcif. Tissue Int. 2003, 72, 537. 
(61) Guerra-Lopez, J. R.; Guida, J. A.; Della Vedova, C. O.; Garcia, R. R. Acta Bioquim. Clin. Latinoam. 2008, 42, 189.

(62) Guerra-Lopez, J. R.; Guida, J. A.; Della Vedova, C. O. Urol. Res. 2010, 38, 383.

(63) http://www.lightsources.org/cms/ (accessed January 2012).

(64) Lynn, G. W.; Heller, W.; Urban, V.; Wignall, G. D.; Weiss, K.; Myles, D. A. A. Phys. B (Amsterdam, Neth.) 2006, 385-386, 880.

(65) Kehayias, J. J.; Smith, D. E.; Roubenoff, R.; Savicki, M.; Zhuang, H. Appl. Radiat. Isot. 1998, 49, 737.

(66) Sharp, D. Lancet 2007, 369, 1982.

(67) Sorensen, Th. L-M.; McAuley, K. E.; Flaig, R.; Duke, E. M.H. Trends Biotechnol. 2006, 24, 500.

(68) Eichert, D.; Salome, M.; Bleuet, P.; Bohic, S.; Susini, J. Proceedings of the 8th International Conference on X-ray Microscopy, IPAP Conference Series 7; Institute of Pure and Applied Physics: Tokyo, Japan, 2006; pp 210-212.

(69) Bazin, D.; Daudon, M.; Chevallier, P.; Rouzière, S.; Elkaim, E.; Thiaudiere, D.; Fayard, B.; Foy, E.; Albouy, P. A.; André, G.; Matzen, G.; Veron, E. Ann. Biol. Clin. 2006, 64, 125.

(70) Carmona, A.; Deves, G.; Roudeau, S.; Cloetens, P.; Bohic, S.; Ortega, R. ACS Chem. Neurosci. 2010, 1, 194.

(71) Lewis, D. J.; Bruce, C.; Bohic, S.; Cloetens, P.; Hammond, S. P.; Arbon, D.; Blair-Reid, S.; Pikramenou, Z.; Kysela, B. Nanomedicine 2010, 5, 1547 .

(72) McKelvy, M. L.; Britt, T. R.; Davis, B. L.; Gillie, J. K.; Graves, F. B.; Lentz, L. A. Anal. Chem. 1998, 70, 119R.

(73) Dumas, P.; Sockalingum, G. D.; Sulé-Suso, J. Trends Biotechnol. 2007, 25, 40

(74) Bazin, D.; Guczi, L; Lynch, J Appl. Catal., A 2002, 226, 87.

(75) Hodeau, J. L.; Favre-Nicolin, V.; Bos, S.; Renevier, H.; Lorenzo, E.; Berar, J. F. Chem. Rev. 2001, 101, 1843.

(76) Bazin, D.; Sayers, D. A.; Rehr, J. J. J. Phys. Chem. B 1997, 101, 11040.

(77) Zavarin, M.; Doner, H. E. Geochem. Trans. 2002, 3, 51.

(78) Chevallier, P.; Dhez, P.; Erko, A.; Firsov, A.; Legrand, F.; Populus, P Nucl. Instrum. Methods Phys. Res., Sect. B 1996, 113, 122.

(79) Bressler, C.; Chergui, M. Chem. Rev. 2004, 104, 1781.

(80) Siritapetawee, J.; Pattanasiriwisawa, W. J. Synchrotron Radiat. 2008, 15, 158.

(81) Mathew, M.; Takagi, S. J. Res. Natl. Inst. Stand. Technol. 2001, 106, 1035.

(82) Conti, C.; Brambilla, L.; Colombo, Ch.; Dellasega, D.; Diego Gatta, G.; Realini, M.; Zerbi, G. Phys. Chem. Chem. Phys. 2010, 12, 14560.

(83) Yamakawa, K.; Iwasaki, H.; Ohjimi, Y.; Kikuchi, M.; Iwashita, A.; Isayama, T.; Naito, M. Pathol., Res. Pract. 2001, 197, 499.

(84) Davis, R. L.; Robertson, D. M. Textbook of Neuropathology, 2nd ed.; Williams and Wilkins: Baltimore, MD, 1991.

(85) Kapila, A. Radiology 1984, 153, 685.

(86) Casanova, M. F.; Araque, J. M. Psychiatry Res. 2003, 121, 59.

(87) Litvin, Y.; Rosler, A.; Bloom, R. A. Neuroradiology 1981, 21, 271.

(88) Calvani, M., Jr; Parisi, P.; Guaitolini, C.; Parisi, G.; Paolone, G.

Eur. J. Pediatr. 2001, 160, 288.

(89) Tabar, L.; Tot, T.; Dean, P. Breast Cancer-Early Detection with Mammography: Casting Type Calcifications: Sign of a Subtype with Deceptive Features; Thieme: New York, 2007.

(90) Castellanos, M.; Varma, S.; Ahern, K.; Grosso, S. J.; Buchbinder, S.; D’Angelo, D.; Raia, C.; Kleiner, M.; Elsayegh, S. Am. J. Kidney Dis. 2006, 48, 301.

(91) Cowlam, T. E.; Bucknall, T. E. Breast 2003, 12, 342.

(92) Swamy, R. Diagn. Histopathol. 2009, 15, 582.

(93) Mccarty, D. J., Jr.; Hogan, J. M.; Gatter, R. A.; Grossman, R. J. Bone Jt. Surg., Am. Vol. 1966, 48, 309.

(94) Nakagawa, Y.; Shimizu, K.; Hamamoto, T.; Kotani, S.; Yamamuro, T. Calcif. Tissue Int. 1993, 53, 127.

(95) Shapiro, I. M.; Golub, E. E.; May, M.; Rabinowitz, J. L. Biosci. Rep. 1983, 3, 345.
(96) Dorfmüller, P.; Bazin, D.; Aubert, S.; Weil, R.; Brisset, F.; Daudon, M.; Capron, F.; Brochériou, I. Cardiol. Res. Pract. 2010, 2010, 685926.

(97) Perrotta, I.; Russo, E.; Camastra, C.; Filice, G.; Di Mizio, G.; Colosimo, F.; Ricci, P.; Tripepi, S.; Amorosi, A.; Triumbari, F.; Donato, G. Histopathology 2011, 59, 504.

(98) Makiishi-Shimobayashi, C.; Tsujimura, T.; Iwasaki, T.; Kakihana, M.; Shimano, K.; Terada, N.; Sakagami, M. Auris, Nasus, Larynx 2004, 31, 3.

(99) Johnson, C. D. Medicine 2007, 35, 116.

(100) Balestreri, L.; Canzonieri, V.; Morassut, S. Clin. Imaging 1997, 21,122 .

(101) Kaufmann, R. B.; Sheedy, P. F., 2nd; Breen, J. F.; Kelzenberg, J. R.; Kruger, B. L.; Schwartz, R. S.; Moll, P. P. Radiology 1994, $190,347$.

(102) De Moraes, C. R. Pediatr. Radiol. 1986, 16, 424.

(103) Fataar, S.; Bassiony, H.; Satyanah, S.; Rudwan, M.; Hebbar, G.; Khalifa, A.; Cherian, M. J. AJR, Am. J. Roentgenol. 1985, 144, 75.

(104) Miller, N. L.; Evan, A. P.; Lingeman, J. E. Urol. Clin. North Am. 2007, 34, 295

(105) Daudon, M.; Bazin, D.; Adil, K.; Le Bail, A. Acta Crystallogr. 2011, E67, o1458.

(106) Daudon, M.; Bouzidi, H.; Bazin, D. Urol. Res. 2010, 38, 459.

(107) Le Bail, A.; Bazin, D.; Daudon, M.; Brochot, B.; RobbezMasson, V.; Maisonneuve, V Acta Crystallogr. 2009, B65, 350.

(108) Rodriguez-Romero, R.; Vargas-Serrano, B.; Cortina-Moreno, B.; Fernandez-Gallardo, J. M.; Cervera-Rodilla, J. L. Am. J. Neuroradiol. 1996, 17, 1491.

(109) Strauss, S. AJR, Am. J. Roentgenol. 2000, 174, 223.

(110) Paley, M. R.; Ros, P. R. Radiol. Clin. North Am. 1998, 36, 391.

(111) Ladefoged, C.; Frifelt, J. J. Virchows Arch. 1987, 410, 461.

(112) Lanitis, A.; Toso, Ch. Hepatology 2011, 53, 1397.

(113) Bestetti-Bosisio, M.; Cotelli, F.; Schiaffino, E.; Sorgato, G.; Schmid, C. Histopathology 1984, 8, 69.

(114) Sanders, C.; Frank, M. S.; Rostang, S. G.; Rutsky, E. A.; Barnes, G. T.; Fraser, R. G. AJR, Am. J. Roentgenol. 1987, 149, 881.

(115) Sontag, L. W.; Allen, J. E. J. Pediatrics 1947, 30, 657.

(116) Narasimhulu, K. V.; Gopal, N. O.; Rao, J. L.; Vijayalakshmi, N.; Natarajan, S.; Surendran, R.; Mohan, V. Biophys. Chem. 2005, 114, 137.

(117) Lesniak, R. J.; Hohenwalter, M. D.; Taylor, A. J. AJR, Am. J. Roentgenol. 2002, 178, 79.

(118) Taylor, J. S. Br. J. Urol. 1998, 81, 645.

(119) Suh, J. H.; Gardner, J. H.; Kee, K. H.; Shen, S.; Ayala, A. G.; Ro, J. Y. Ann. Diagn. Pathol. 2008, 12, 165.

(120) Rabinov, J. D. Radiol. Clin. North Am. 2000, 38, 1047.

(121) Bigi, A.; Ripamonti, A.; Roveri, N.; Dovigo, L.; Scaramelli, M. Inorg. Chim. Acta 1983, 79, 292.

(122) Rashid, H. H.; Cos, L. R.; Weinberg, E.; Messing, E. M. Urol. Oncol.: Sem. Orig. Invest. 2004, 22, 285.

(123) Renshaw, A. A. J. Urol. 1998, 160, 1625.

(124) Weirich, T. E.; Aretz, A.; Schlieper, G.; Mayer, J.; Ketteler, M.; Floege, J. J. Synchrotron Rad. 2001, 8, 990.

(125) Taki, S.; Terahata, S.; Yamashita, R.; Kinuyad, K.; Nobatae, K.; Kakudae, K.; Kodama, Y.; Yamamoto, I. Clin. Imaging 2004, 28, 368.

(126) Khoo, M. L.; Asa, S. L.; Witterick, I. J.; Freeman, J. L. Head Neck 2002, 24, 651.

(127) Gomez, N. R.; Kouniavsky, G.; Tsai, H. L.; Somervell, H.; Pai, S. I.; Tufano, R. P.; Umbricht, Ch.; Kowalski, J.; Dackiw, A. P. D.; Zeiger, M. A. J. Surg. Oncol. 2011, 104, 613.

(128) Boström, K. Am. J. Cardiol. 2001, 88, 20.

(129) Jono, S.; McKee, M. D.; Murry, C. E.; Shioi, A.; Nishizawa, Y.; Mori, K.; Morii, H.; Giachelli, C. M. Circ. Res. 2000, 87, e10.

(130) Weirich, T. E.; Aretz, A.; Schlieper, G.; Mayer, J.; Ketteler, M.; Floege, J. Acta Crystallogr. 2006, A62, s186.

(131) El-Abbadi, M.; Giachelli, C. M. Adv. Chronic Kidney Dis. 2007, 14,54 .

(132) Trion, A.; Van der Laarse, A. Am. Heart J. 2004, 147, 808.

(133) Tran, K. H.; Ines Boechat, M. Pediatr. Radiol. 2006, 36, 247.

(134) Cronin, C. C.; O’ Sullivan, D. J.; Mitchell, T. H. Diabetic Med. 1996, 13,768 
(135) Groisman, G. M.; Amar, M.; Polak-Charcon, S. Hum. Pathol. 1999, 30, 199.

(136) Anjum, U.; Butler, B.; Koehn, D. Ultrasound Obstet. Gynecol. 2011, 38, 197.

(137) Poggi, S. H.; Bostrom, K. I.; Demer, L. L.; Skinner, H. C.; Koos, B. J. Placenta 2001, 22, 591.

(138) Shen, M.; Lajos, P. S.; Farge, D.; Daudon, M.; Carpentier, S. M.; Chen, L.; Martinet, B.; Carpentier, A. F. Ann. Thorac. Surg. 1998, 6, 236.

(139) Leskelä, H. V.; Satta, J.; Oiva, J.; Eriksen, H.; Juha, R.; Korkiamäki, P.; Ivaska, K. K.; Soini, Y.; Lehenkari, P. J. Mol. Cell. Cardiol. 2006, 41, 642.

(140) Bernacca, G. M.; Fisher, A. C.; Mackay, T. G.; Wheatley, D. J. J. Mater. Sci.: Mater. Med. 1992, 3, 293.

(141) Hahn, S. K.; Ohri, R.; Giachelli, C. M. Biotechnol. Bioprocess Eng. 2005, 10, 218.

(142) Peters, W.; Pritker, K.; Smith, D.; Fornasier, V.; Holmyard, D.; Lugowski, S.; Kamel, M.; Visram, F. Ann. Plast. Surg. 1998, 41, 348.

(143) Patai, K.; Berényi, M.; Sipos, M.; Noszál, B. Contraception 1998, 58, 305.

(144) Traxer, O.; Daudon, M.; Dore, B.; Amiel, J.; Hadjadj, H.; Conort, P.; Lechevallier, E.; Meria, P.; Saussine, C. Eur. Urol., Suppl. 2006, 5, 70 .

(145) Halwani, D. O.; Anderson, P. G.; Brott, B. C.; Anayiotos, A. S.; Lemons, J. E. J. Biomed. Mater. Res., Part B 2012, 100B, 292.

(146) Pandey, S. K.; Werner, L.; Apple, D. J.; Kaskaloglu, M. Ophthalmology 2002, 109, 2042.

(147) Wu, W.; Guan, R.; Tang, R.; Hook, D.; Yan, W.; Grobe, G.; Nancollas, G. H. Langmuir 2004, 20, 1356.

(148) Stringham, J.; Werner, L.; Monson, B.; Theodosis, R.; Mamalis, N. Ophthalmology 2010, 117, 1486.

(149) Cochat, P. Kidney Int. 1999, 55, 2533.

(150) Leumann, E.; Hoppe, B. J. Am. Soc. Nephrol. 2001, 12, 1986.

(151) Bollée, G.; Dollinger, C.; Boutaud, L.; Guillemot, D.; Bensman., A.; Harambat, J.; Deteix, P.; Daudon, M.; Knebelmann, K.; Ceballos-Picot, I. J. Am. Soc. Nephrol. 2010, 21, 679.

(152) Giachelli, C. M. J. Am. Soc. Nephrol. 2003, 14, S300.

(153) Sun, Y.; Zeng, X. R.; Wenger, L.; Cheung, H. S. Biochem. Biophys. Res. Commun. 2003, 312.

(154) Hsu, H. H. T.; Abbo, B. G. Biochim. Biophys. Acta, Mol. Basis Dis. 2004, 1690, 118.

(155) Steitz, S. A.; Speer, M. Y.; McKee, M. D.; Liaw, L.; Almeida, M.; Yang, H.; Giachelli, C. M. Am. J. Pathol. 2002, 161, 2035.

(156) Vogel, P. M.; Georgiade, N. G.; Fetter, B. F.; Vogel, F. S.; McCarty, K. S. Am. J. Pathol. 1981, 104, 23.

(157) Guinebretière, J. M.; Menet, E.; Tardivon, A.; Cherel, P.; Vanel, D. Eur. J. Radiol. 2005, 54.

(158) Klimas, R.; Bennett, B.; Gardner, W. A., Jr. Prostate 2006, 7, 91.

(159) Moskowitz, M. A.; Winickoff, R. N.; Heinz, E. R. N. Engl. J. Med. 1971, 285, 72.

(160) Harrington, M. G.; Macpherson, P.; McIntosh, W. B.; Allam, B. F.; Bone, I. J. Neurol., Neurosurg. Psychiatry 1981, 44, 1168.

(161) Li, J. J.; Zhu, C. G.; Yu, B.; Liu, Y. X.; Yu, M. Y. Aging Res. Rev. 2007, 6, 263

(162) Woods, J. E.; Soh, S.; Wheeler, T. M. Arch. Pathol. Lab. Med. 1998, 122, 152.

(163) Bach, A. M.; Hann, L. E.; Hadar, O.; Shi, W.; Yoo, H. H.; Giess, C. S.; Sheinfeld, J.; Thaler, H. Radiology 2001, 220, 70.

(164) Gahl, W. A.; Thoene, J. G.; Schneider, J. A. N. Engl. J. Med. 2002, 347, 111.

(165) Kajander, E. O.; Ciftçioglu, N. Proc. Natl. Acad. Sci. U.S.A. 1998, 95, 8274.

(166) Çiftçioglu, N.; Kajander, E. O. Pathophysiology 1998, 4, 259.

(167) Aloisi, G. Biosci. Hypotheses 2008, 1, 138.

(168) Southam, G.; Donald, R. Earth-Sci. Rev. 1999, 48, 251.

(169) Dorrell, S. Mol. Med. Today 1999, 5, 373.

(170) Jones, J. A.; Ciftcioglu, N.; Schmid, J. F.; Barr, Y. R.; Griffith, D. Urology 2009, 73, 210.e11.
(171) Raoult, D.; Drancourt, M.; Azza, S.; Nappez, C.; Guieu, R.; Rolain, J. M.; Fourquet, -P.; Campagna, B.; La Scola, B.; Mege, J. L.; Mansuelle, P.; Lechevalier, E.; Berland, Y.; Gorvel, J. P.; Renesto, P. PLoS Pathog. 2008, 4, e41.

(172) Doherty, T. M.; Asotra, K.; Fitzpatrick, L. A.; Qiao, J. H.; Wilkin, D. J.; Detrano, R. C.; Dunstan, C. R; Shah, P. K.; Rajavashisth, T. B. Proc. Natl. Acad. Sci. U.S.A. 2003, 100, 11201.

(173) Lairda, D. F.; Mucaloa, M. R.; Yokogawa, Y. J. Colloid Interface Sci. 2006, 295, 348.

(174) Fleming, D. E.; Van Riessen, A.; Chauvet, M. C.; Grover, P. K.; Hunter, B.; van Bronswijk, W.; Ryall, R. M. J. Bone Miner. Res. 2003, 18, 1282.

(175) Randall, A. Ann. Surg. 1937, 105, 1009.

(176) Matlaga, B. R.; Coe, F. L.; Evan, A. P.; Lingeman, J. E. J. Urol. 2007, 177, 31 .

(177) Low, R. K.; Stoller, M. L. J. Urol. 1997, 158, 2062.

(178) Evan, A. P.; Lingeman, J. E.; Coe, F. L.; Parks, J. H.; Bledsoe, S. B.; Shao, Y.; Sommer, A. J.; Paterson, R. F.; Kuo, R. L.; Grynpas, G. J. Clin. Invest. 2003, 111, 607.

(179) Kim, S. C.; Coe, F. L.; Tinmouth, W. W.; Kuo, R. L.; Paterson, R. F.; Parks, J. H.; Munch, L. C.; Evan, A. P.; Lingeman, J. E. J. Urol. 2005, 173, 117.

(180) Kuo, R. L.; Lingeman, J. E.; Evan, A. P.; Paterson, R. F.; Parks, J. H.; Bledsoe, S. B.; Munch, L. C.; Coe, F. L. Kidney Int. 2003, 64, 2150.

(181) Daudon, M.; Traxer, O.; Jungers, P.; Bazin, D. Renal Stone Dis. 2007, 900, 26.

(182) Lowenstam, H. A. Science 1981, 211, 1126.

(183) Lowenstam, H. A.; Mineralization processes in monerans and protoctists. In Biomineralization in Lower Plants and Animals; Leadbeater, B.S.C., Riding, R., Eds.; Oxford University Press: New York, 1986; pp 1-17.

(184) Baeuerlein, E., Biomineralization: From Biology to Biotechnology and Medical Application; Wiley-VCH: Weinheim, Germany, 2000.

(185) Dove, P. M., Weiner, S., De Yoreo, J. J., Eds. Biomineralization. Rev. Mineral. Geochem.; Mineralogical Society of America: Washington, D.C., v. 54, 2003.

(186) De Ricqlès, A.; Livage, J. C. R. Palevol 2004, 3, 435.

(187) Boskey, A. L. Connect. Tissue Res. 2003, 44, 5.

(188) Lowenstam, H. A.; Weiner, S. On Biomineralization; Oxford University Press: New York, 1989.

(189) Tan, J.; Saltzman, W. M. Biomaterials 2004, 25, 3593.

(190) Daudon, M.; Estépa, L.; Viard, J. P.; D Joly, D.; Jungers, P. Lancet 1997, 349, 1294.

(191) Nguyen, Ch.; Ea, H. K.; Bazin, D.; Daudon, M.; Lioté, F. Arthritis Rheum.. 2010, 62, 2829.

(192) Ledingham, J.; Regan, M.; Jones, A.; Doherty, M. Ann. Rheum. Dis. 1993, 52, 520.

(193) Lagier, R.; Baud, C. A. Pathol., Res. Pract. 2003, 199, 329.

(194) Nguyen, Ch.; Ea, H. K.; Meyer, M.; Weil, R.; Nizard, R.; Daudon, M.; Bazin, D.; Lioté, F. Rev. Rhumatol. 2009, 76, 990.

(195) Kopans, D.; Gavenonis, S.; Halpern, E.; Moore, R. Breast J. 2011, 17, 638

(196) Stephens, A. D. J. Inherited Metab. Dis. 1989, 12, 197.

(197) Barbey, F.; Joly, D.; Rieu, Ph.; Méjean, A.; Daudon, M.; Jungers, P. J. Urol. 2000, 163, 1419.

(198) Bellanato, J.; Cifuentes, J. L. R. M.; Salvador, E.; Medina, J. A. Int. J. of Urol. 2009, 16, 318.

(199) Ropion-Michaux, H.; Mathias, J.; Bruot, O.; Ganne, P. A.; Laurent, V.; Régent, D. J. Radiol. 2010, 91, 759.

(200) Den Bakker, M. A.; den Bakker, A. J.; Beenen, R.; Mulder, A. H.; Eulderink, F. Pathol., Res. Pract. 1998, 194, 189.

(201) Haddow, R. A.; Kemp-Harper, R. A. Clin. Radiol. 1967, 18, 225.

(202) Kazmierski, R. H. Am. J. Surg. 1951, 82, 248.

(203) Ishida, J.; Ajiki, T.; Hara, S.; Ku, Y. Surgery 2012, DOI: doi: 10.1016/j.surg.2011.07.033.

(204) Kianmanesh, R.; Scaringi, S.; Castel, B.; Flamant, Y.; Msika, S. J. Chir. 2007, 144, 278. 
(205) Itou, Y.; Kataoka, T. R.; Takashima, S. Eur. J. Radiol. Extra 2009, 71, e65.

(206) Matsuda, I.; Hao, H.; Zozumi, M.; Koishi, M.; Matsumoto, T.; Kaibe, N.; Fujiwara, Y.; Sasako, M.; Hirota, S. Pathol., Res. Pract. 2010, 206, 372.

(207) Oka, R.; Okai, T.; Kitakata, H.; Ohta, T. Gastrointest. Endoscopy 2002, 56, 939.

(208) Dessombz, A.; Méria, P.; Bazin, D.; Foy, E.; Rouzière, S.; Weil, R.; Daudon, M. Prog. Urol. 2011, 21, 940.

(209) Hanna, S. A.; Pimenta Neves-Junior, W. F.; Marta, G. N.; Kalil Haddad, C. M.; Fernandes da Silva, J. L. Int. J. Radiat. Oncol., Biol., Phys. 2012, 82 (3), 1208.

(210) Zeng, G. G.; McGowan, T. S.; Larsen, T. M.; Bruce, L. M.; Moran, N. K.; Tsao, J. R.; MacPherson, M. S. Int. J. Radiat. Oncol., Biol., Phys. 2008, 72, 963.

(211) Dudley, A. C.; Khan, Z. A.; Shih, S. C.; Kang, S. Y.; Zwaans, B. M. M.; Bischoff, J.; Klagsbrun, M. Cancer Cell 2008, 14, 201.

(212) González-Arriagada, W. A.; Santos-Silva, A. R.; Ito, F. A.; Vargas, P. A.; Lopes, M. A. Oral Surg., Oral Med., Oral Pathol., Oral Radiol., and Endodontol. 2011, 111, 482.

(213) Ertas, U.; Tozoglu, S.; Gundogdu, C. J. Oral Maxillofacial Surg. 2006, 64, 1684.

(214) Harrison, J. D. Otolaryngol. Clin. North Am. 2009, 42, 927.

(215) Reid, J. D.; Andersen, M. E. Atherosclerosis 1993, 101, 213.

(216) Silveira, L.; Sathaiah, S.; Zângaro, R. A.; Tavares Pacheco, M.

T.; Chavantes, M. C.; Pasqualucci, C. A. J. Clin. Laser Med. Surg. 2003, 21, 203.

(217) Greenebaum, E. Hum. Pathol. 1980, 11, 287.

(218) Mommers, X.-A.; Henault, B.; Aubriot, M.-H.; Trost, O.; Malka, G.; Zwetyenga, N. Rev. Stomatol. Chir. Maxillo-faciale 2012, 113 (1), 53.

(219) Eisenstein, D. M.; Paller, A.; Pachman, L. M. Pediatrics 1997, $100,391$.

(220) Low Wang, C. C.; Sorribas, V.; Sharma, G.; Levi, M.; Draznin, B. Atherosclerosis 2007, 195, e65.

(221) Lu, W.; Wang, X.; Zhao, X. J. Nanjing Med. Univ. 2007, 21, 377.

(222) Maccotta, O.; Toulze, R.; Beya, R.; Vasse, B. J. Traumatol. Sport 2011, 28, 197.

(223) Frausto da Silva, J. J. R; Williams, R. P. J. The Biological Chemistry of the Elements; Clarendon: Oxford, U.K., 1991; Chapter 10.

(224) White, T.; Ferraris, C.; Kim, J.; Madhavi, S. Rev. Mineral. Geochem. 2005, 57, 307.

(225) White, T. J.; ZhiLi, D. Acta Crystallogr. 2003, B59, 1.

(226) Eichert, D.; Salome, M.; Banu, M. Spectrochim. Acta B 2005, 60, 850 .

(227) Rey, C.; Miquel, J. L.; Facchini, L.; Legrand, A. P.; Glimcher, M. J. Bone 1995, 16, 583.

(228) Cho, G.; Wu, Y.; Ackerman, J. L. Science 2003, 300, 1123.

(229) Vallet-Reg1, M.; Gonzalez-Calbet, J. M. Prog. Solid State Chem. 2004, 32, 1 .

(230) Grynpas, M. D.; Holmyard, D. Scanning Microsc. 1988, 2, 1045.

(231) Nancollas, G. H. Pure Appl. Chem. 1992, 64, 1673.

(232) Boistelle, R.; Astier, J. P. J. Cryst. Growth 1988, 90, 14.

(233) Nancollas, G. H. The nucleation and growth of phosphate minerals. In Phosphate Minerals; Nriagu, J.O., Ed.; Springer-Verlag: New York, 1984; p 137.

(234) Iijima, M.; Kamemizu, H.; Wakamatsu, N.; Goto, T.; Doi, Y.; Moriwaki, Y. J. Cryst. Growth 1994, 135, 229.

(235) Mullin, J. W. In Crystallization, 2nd ed.; Butterworths: London, 1972; pp 146-149.

(236) Koutsoukos, P. G.; Nancollas, G. H. J. Cryst. Growth 1981, 53, 10.

(237) Boistelle, R; Rinaudo, C. J. Cryst. Growth 1981, 53, 1.

(238) Pak, C. Y. C. J. Cryst. Growth 1981, 53, 202.

(239) Tang, R.; Henneman, J.; Nancollas, G. H. J. Cryst. Growth 2003, 249, 614 .

(240) Omar, N. B.; Gonzalez-Muñoz, M. T.; Arias Peñalver, J. M. Chemosphere 1998, 36, 475.
(241) Cazalbou, S.; Combes, C.; Eichert, D.; Rey, C J. Mater. Chem. 2004, 14, 2148.

(242) Cazalbou, S.; Combes, C.; Eichert, D.; Rey, C.; Glimcher, M. J. J. Bone Mineral. Metab. 2004, 22, 310.

(243) Kapolos, J.; Koutsoukos, P. G. Langmuir 1999, 15, 6557.

(244) Elliott, J. C.. Structure and Chemistry of the Apatites and Other Calcium Orthophosphates; Elsevier: Amsterdam, 1994.

(245) Combes, C.; Rey, C.; Mounic, S. Key Eng. Mater. 2001, 195196, 143.

(246) Hamad, M.; Heughebaert, J. C. J. Cryst. Growth 1996, 79, 192.

(247) Mijangos, F.; Kamel, M.; Lesmes, G.; Muraviev, D. N. React. Funct. Polym. 2004, 61, 151.

(248) Franchini-Angela, M.; Aquilano, D. J. Cryst. Growth 1979, 47, 719.

(249) Latham, P. W. Lancet 1886, 127, 244.

(250) Kumta, P. N.; Sfeir, C.; Lee, D. H.; Olton, D.; Choi, D. Acta Biomater. 2005, 1, 65 .

(251) Nancollas, G. H.; Smesko, S. A.; Campbell, A. A.; Richardson, C. F.; Iadiccico, R. A.; Binette, J. P.; Binette, M. Am. J. Kidney Dis. 1991, 17, 392.

(252) Wu, W.; Gerard, D. E.; Nancollas, G. H. J. Am. Soc. Nephrol. 1999,10, S355.

(253) Campbell, A. A.; Ebrahimpour, A.; Perez, L.; Smesko, S. A.; Nancollas, G. H. Calcif. Tissue Int. 1989, 45, 122.

(254) Lanzalaco, A. C.; Singh, R. P.; Smesko, S. A.; Nancollas, G. H.; Sufrin, G.; Binette, M.; Binette, J. P. J. Urol. 1988, 139, 190.

(255) Tang, R; Nancollas, G. H.; Giocondo, J. L.; Hoyer, J. R.; Orme, C. A. Kidney Int. 2006, 70, 71.

(256) Kanakis, J.; Malkaj, P.; Petroheilos, J.; Dalas, E. J. Cryst. Growth 2001, 223, 557.

(257) White, D. J.; Coyle-Rees, M.; Nancollas, G. H. Calcif. Tissue Int. 1988, 43, 319.

(258) Randolph, A. D.; Drach, G. W. J. Cryst. Growth 1981, 53, 195.

(259) Sheng, X.; Ward, M. D.; Wesson, J. A. J. Am. Soc. Nephrol. 2005, 16, 1904.

(260) Grover, P. K.; Ryall, R. L.; Marshall, V. R. Clin. Chim. Acta 1990, 190, 129.

(261) Yoshioka, T.; Koide, T.; Utsunomiya, M.; Itatani, H.; Oka, T.; Sonoda, T. Br. J. Urol. 1989, 64, 463.

(262) Ryall, R.; Harnett, R. M.; Hibberd, C. M.; Edyvane, K. A.; Marshall, V. R. Urol. Res 1991, 19, 181.

(263) Nakagawa, Y.; Ahmed, M.; Hall, S. L.; Deganello, S.; Coe, F. L. J. Clin. Invest 1987, 79, 1782.

(264) Worcester, E. M.; Sebastian, J. L.; Hiatt, J. G.; Beshensky, A. M.; Sadowski, J. A. Calcif. Tissue Int. 1993, 53, 242.

(265) Tang, Y.; Grover, P.; Moritz, R.; Simpson, R.; Ryall, R. Br. J. Urol. 1995, 76, 425.

(266) Baumann, J. M.; Affolter, B.; Caprez, U.; Henze, U. Eur. Urol. 2003, 43, 421.

(267) Konya, E.; Umekawa, T.; Iguchi, M.; Kurita, T. Eur. Urol. 2003, 43, 564 .

(268) Ryall, R. L.; Chauvet, M. C.; Grover, P. K. Br. J. Urol. Int. 2005, 96, 654 .

(269) Grover, P. K.; Moritz, R. L.; Simpson, R. J.; Ryall, R. L. Eur. J. Biochem. 1998, 253, 637.

(270) Rosenthal, A. K.; Gohra, C. M.; Uzukia, M.; Masuda, I. Matrix Biol. 2007, 26, 96.

(271) Qiu, S. R.; Wierzbicki, A.; Orme, C. A.; Cody, A. M.; Hoyer, J. R.; Nancollas, G. H.; Zepeda, S.; De Yoreo, J J. Proc. Natl. Acad. Sci. U.S.A. 2004, 101, 1811.

(272) Cheung, H. S.; Sallis, J. D.; Struve, J. A. Biochim. Biophys. Acta, Mol. Basis Dis. 1996, 1315, 105.

(273) Krasovskaya, S. M.; Uzhinova, L. D.; Andrianova, Y. M.; Prischenko, A. A.; Livantsov, M. V.; Lomonosov, M. V. Biomaterials 1991, 12, 817.

(274) Lussi, A.; Crenshaw, M. A.; Linde, A. Arch. Oral. Biol. 1988, 33, 685.

(275) Addadi, L.; Moradian-Oldak, J.; Füredi-Milhofer, H.; Weiner, S.; Veis, A. In Chemistry and Biology of Mineralized Tissues, Excerpta 
Medica; Slavkin, H., Price, P., Eds.; Elsevier Science Publishers B.V.: London, 1992; pp 153-162.

(276) Mueller, E.; Sikes, C. S. Calcif. Tissue Int. 1993, 52, 34.

(277) Combes, C.; Rey, C.; Frèche, M. J. Mater. Sci.: Mater. Med. 1999, 10, 153.

(278) Combes, C.; Rey, C. Biomaterials 2002, 23, 2817.

(279) Ebrahimpour, A.; Perez, L.; Nancollas, G. H. Langmuir 1991, 7, 577.

(280) Christoffersen, J.; Christoffersen, M. R. J. Cryst. Growth 1981, 53,42 .

(281) Davey, R. J. J. Cryst. Growth 1976, 34, 109.

(282) Boskey, A. L.; Maresca, M.; Doty, S.; Sabsay, B.; Veis, A. Bone Miner. 1990, 11, 55.

(283) Corrand, D. M.; Czernuszka, J. T. In Calcium Phosphate Materials; Fundamentals; Brès, E, Hardouin, P, Eds.; Sauramps Medical: Paris, 1998.

(284) Davey, R. J. In Industrial Crystallization '78; de Jong, E. J., Jancic, S. J., Eds.; Elsevier: London, 1979; pp 169-183.

(285) Garnett, J.; Dieppe, P. Biochem. J. 1990, 266, 863.

(286) Richardson, C. F.; Johnsson, M.; Raj, P. A.; Levine, M. J.; Nancollas, G. H. Arch. Oral Biol. 1993, 38, 997.

(287) Sheha, R. R. J. Colloid Interface Sci. 2007, 310, 18.

(288) Miller, L. M.; Dumas, P. Biochim. Biophys. Acta 2006, 1758, 846.

(289) Klein, B.; Weissman, M.; Berkowitz, J. Clin. Chem. 1960, 6, 453.

(290) Nguyen Quy, D; Daudon, M Infrared et Raman Spectra of Calculi; Elsevier: Paris, 1997.

(291) Li, C.; Ebenstein, D.; Xu, C.; Chapman, C.; Saloner, D.; Rapp, J.; Pruitt, L. J. Biomed. Mater. Res., Part A 2003, 64A, 197.

(292) Rey, Ch; Combes, Ch.; Drouet, Ch.; Glimcher, M. J. Osteoporosis Int. 2009, 20, 1013.

(293) Miller, L. M.; Vairavamurthy, V.; Chance, M. R.; Mendelsohn, R.; Paschalis, E. P.; Betts, F.; Boskey, A. L. Biochim. Biophys. Acta 2001, 1527, 11.

(294) Huang, R. Y.; Miller, L. M.; Carlson, C. S.; Chance, M. R. Bone 2002, 3, 492.

(295) Mendelsohn, R.; Hassankhani, A.; DiCarlo, E.; Boskey, A. Calcif. Tissue Int. 1989, 44, 20.

(296) Williams, G. P. Nucl. Instrum. Methods Phys. Res., Sect. A 1990, 291, 8.

(297) Duncan, W.; Williams, G. P. Appl. Opt. 1983, 22, 2914.

(298) Creagh, D.; Mc Kinlay, J.; Dumas, P. Radiat. Phys. Chem. 2006, $75,1995$.

(299) Dumas, P.; Polack, F.; Lagarde, B.; Chibar, O.; Giorgetta, S.; Lefrançois, S. Infrared Phys. Technol. 2006, 49, 152.

(300) Cotte, M.; Dumas, P.; Richard, G.; Breniaux, R.; Walter, Ph. Anal. Chim. Acta 2005, 553, 105.

(301) Guilhaumou, N.; Sautter, V.; Dumas, P. Chem. Geol. 2005, 223, 82.

(302) Dumas, P.; Miller, L. Vib. Spectrosc. 2003, 32, 3.

(303) Boskey, A. L.; Mendelsohn, R. Vib. Spectrosc. 2005, 38, 107.

(304) Baker, R. N.; Smith, J.; Rogers, K. D.; Stone, N. Biomedical Vib. Spectrosc. III: Advances in Research and Industry, Proceedings of the SPIE; Mahadevan-Jansen, A., Petrich, W. H., Eds.; Bellingham, WA, 2006; Vol. 6093, p 221.

(305) Miller, L .M.; Wang, Q.; Smith, R. J.; Zhong, H.; Elliott, D.; Warren, J. Anal. Bioanal. Chem. 2007, 387, 1705.

(306) Kalasinsky, K. S.; Kalasinsky, V. F. Spectrochim. Acta, Part A 2005, 61, 1707.

(307) Pachman, L. M.; Veis, A.; Stock, S.; Abbott, K.; Vicari, F.; Patel, P. Arthritis Rheum. 2006, 54, 3345.

(308) Boskey, A.; Pleshko Camacho, N. Biomaterials 2007, 28, 2465.

(309) Narasimhulu, K. V.; Gopal, N. O.; Lakshmana Rao, J.; Vijayalakshmi, N.; Natarajan, S.; Surendran, R.; Mohan, V. Biophys. Chem. 2005, 114, 137.

(310) Servais, A.; Daudon, M.; Knebelman, B. Ann. Urol. 2006, 40, 57.
(311) E.V. Wilson, E. V.; Junaid Bushiri, V.; Vaidyan, V. K. Spectrochim. Acta, Part A 2010, 77, 442.

(312) Toscano, R. A.; Melo Dulce, A.; De Moura, F. V.; Defarias, R. F. Thermochim. Acta 2004, 410, 125.

(313) Mattson, E.; Hirschmugl, C.; Gohr, C. M.; Rosenthal, A. K Osteoarthritis Cartilage 2007, 15, C65.

(314) Dessombz, A.; Bazin, D.; Dumas, P.; Sandt, Ch.; Suso-Sulé, J.; Daudon, M. PLoS One 2011, 6, e28007.

(315) Pijanka, J. K.; Stone, N.; Cinque, G.; Yang, Y.; Kohler, A.; Wehbe, K.; Frogley, M.; Parkes, G.; Parkes, J.; Dumas, P.; Sandt, C.; van Pittius, D. G.; Douce, G.; Sockalingum, G. D.; Sulé-Suso, J. Spectrosc.-Biomed. Appl. 2010, 24, 73.

(316) Pijanka, J.; Sockalingum, G. D.; Kohler, A.; Yang, Y.; Draux, F.; Dumas, P.; Sandt, C.; Parkes, G.; van Pittius, D. G; Douce, G.; Untereiner, V.; Sulé-Suso, J. Lab. Invest. 2010, 90, 797.

(317) Draux, F.; Jeannesson, P.; Gobinet, C; Sulé-Suso, J.; Pijanka, J.; Sandt, C.; Dumas, P.; Manfait, M.; Sockalingum, G. D. Anal. Bioanal. Chem. 2009, 395, 2293.

(318) Pijanka, J. K.; Kumar, D.; Dale, T.; Yousef, I.; Parkes, G.; Untereiner, V.; Yang, Y.; Dumas, P.; Collins, D.; Manfait, M.; Sockalingum, G. D; Forsyth, N. R.; Sulé-Suso, J. Analyst 2010, 135, 3126.

(319) Draux, F.Probing Tumor Cell and Its Ineraction with an Anticancer Agent: A Biophotonic Approach Using Raman and Infrared Spectroscopy; Faculty of Pharmacy, Univeristat Reims: ChampagneArdenne, France, 2009.

(320) Krishna, C. M.; Sockalingum, G. D.; Kegelaer, G.; Rubin, S.; Kartha, V. D.; Manfait, M. Vib. Spectrosc. 2005, 38, 95.

(321) Abramczyk, H.; Surmacki, J.; Brożek-Płuska, B.; Morawiec, Z.; Tazbir, M. Vib. Spectrosc. 2005, 38, 95.

(322) Devpura, S.; Thakur, J. S.; Sarkar, F. H.; Sakr, W. A.; Naik, V. M.; Naik, R. Vib. Spectrosc. 2010, 53, 227.

(323) Shapiro, A.; Gofrit, O. N.; Pizov, G.; Cohen, J. K.; Maier, J. Eur. Urol. 2011, 59, 106.

(324) Feng, S.; Chen, R.; Lin, J.; Pan, J.; Wu, Y.; Li, Y.; Chen, J.; Zeng, H. Biosens. Bioelectron. 2011, 26, 3167.

(325) Harris, A. P.; Lungari, A.; Needham, C. J.; Smith, S. L.; Lones, M. A.; Fisher, S. E. E.; Yang, X. B.; Cooper, N.; Kirkham, J.; Smith, D. A.; Martin-Hirsch, D. P.; High, A. S. Head Neck Oncol. 2009, 1, 34.

(326) Yang, J.; Wang, Z.; Zong, S.; Song, Ch.; Zhang, Rh.; Cui, Y. Anal. Bioanal. Chem. 2012, 402, 1093.

(327) Guinier, A. Théorie et Technique de la Radiocristallographie; Dunod: Paris, 1964

(328) Warren, B.E. X-ray diffraction; Dover: New York, 1990.

(329) Rietveld, H. M. Acta Crystallogr. 1967, 22, 151.

(330) Le Bail, A. NIST Spec. Publ. 1992, 846, 213.

(331) Powder diffraction file (PDF), International centre for diffraction data, 12 campus Blvd, Newton square, PA 19073-3273, USA, http://www.idd.com (accessed January 1990).

(332) Lonardelli, I.; Wenk, H. R.; Lutterotti, L.; Goodwin, M. J. Synchrotron Radiat. 2005, 12, 354.

(333) Heidelbach, F.; Riekel, C.; Wenk, H. R. J. Appl. Crystallogr. 1999, 32, 841.

(334) Sperrin, M. W.; Rogers, K. Br. J. Urol. 1998, 82, 781.

(335) Milev, A. S.; Kamali Kannangara, G. S.; Wilson, M. A. J. Phys. Chem. B. 2004, 108, 13015.

(336) Almer, J. D.; Stock, S. R. J. Struct. Biol. 2005, 152, 14.

(337) Jacquet, J.; Very, J. M.; Flack, H. D. J. Appl. Crystallogr. 1980, 13,380 .

(338) Hamilton, W. C. Acta Crystallogr. 1969, A25, 194.

(339) Wilson, R. M.; Elliott, J. C.; Dowker, S. E. P.; Smith, R. I. Biomaterials 2004, 25, 2205.

(340) Loong, C. K.; Rey, C.; Kuhn, L. T.; Combes, C.; Wu, Y.; Chen, S. H.; Glimcher, M. J. Bone 2000, 26, 599.

(341) Bacon, G. E.; Goodship, A. E. J. Appl. Crystallogr. 2007, 40, 349.

(342) Becker, A.; Epple, M.; Muller, K. M.; Schmitz, I. J. Inorg. Biochem. 2004, 98, 2032.

(343) Ratnasamy, P.; Leonard, A. J. Catal. Rev. Sci. Eng. 1972, 6, 293. 
(344) Bazin, D.; Sayers, D. A. Jpn. J. Appl. Phys. 1993, 32, 249.

(345) Bazin, D.; Sayers, D. A. Jpn. J. Appl. Phys. 1993, 32, 253.

(346) Guagliardi, A.; Cedola, A.; Giannini, C.; Ladisa, M.; Cervellino, A.; Sorrentino, A.; Lagomarsino, S.; Cancedda, R.; Mastrogiacomo, M. Biomaterials 2010, 31, 8289.

(347) DeMaeyer, E.; Verbeeck, R.; Nassens, D. Inorg. Chem. 1993, 32, 5709 .

(348) Zhu, K.; Yanagisawa, K.; Shimanouchi, R.; Onda, A.; Kajiyoshi, K. J. Eur. Ceram. Soc. 2006, 26, 509.

(349) Fenter, P.; Sturchio, N. C. Prog. Surf. Sci. 2004, 77, 171.

(350) Bodier-Houllé, P.; Steuer, P.; Voegel, J. C.; Cuisinier, F. J. G. Cell Tissue Res. 2000, 301, 389.

(351) Bacon, G. E.; Bacon, P. J.; Griffiths, R. K. J. Appl. Crystallogr. 1979, 12, 99.

(352) Cedola, A.; Mastrogiacomo, M.; Lagomarsino, S.; Cancedda, R.; Giannini, C.; Guagliardi, A.; Ladisa, M.; Burghammer, M; Rustichelli, F.; Komlev, V. Spectrochim. Acta, Part B 2007, 62, 642.

(353) Zhou, H.; Burger, C.; Sics, I.; Hsiao, B. S.; Chu, B.; Graham, B.; Glimcher, M. J. J. Appl. Crystallogr. 2007, 40, S666.

(354) Gupta, S.; Roschger, P.; Zizak, I.; Fratzl-Zelman, N.; Nader, A.; Klaushofer, K.; Fratzl, P. Calcif. Tissue Int. 2003, 72, 567.

(355) Zizak, I.; Roschger, P.; Paris, O.; Misof, B. M.; Berzlanovich, A.; Bernstorff, S.; Amenitsch, H.; Klaushofer, H.; Fratzl, P. J. Struct. Biol. 2003, 141, 208.

(356) Kaabar, W.; Daar, E.; Bunk, O.; Farquharson, M. J.; Laklouk, A.; Bailey, M.; Jeynes, C.; Gundogdu, O.; Bradley, D. A. Nucl. Instrum. Methods Phys. Res., Sect. A 2011, 652, 786.

(357) Kaabar, W.; Laklouk, A.; Bunk, O.; Baily, M.; Farquharson, M. J.; Bradley, D. Nucl. Instrum. Methods Phys. Res., Sect. A 2010, 619, 78.

(358) Moger, C. J.; Barrett, R.; Bleuet, P.; Bradley, D. A.; Ellis, R. E.; Green, E. M.; Knapp, K. M.; Muthuvelu, P.; Winlove, C. P. Osteoarthritis Cartilage 2007, 15, 682.

(359) Camacho, N. P.; Rinnerthaler, S.; Paschalis, E. P.; Mendelsohn, R. A.; Boskey, L.; Fratzl, P. Bone 1999, 25, 287.

(360) Sayers, D. E.; Lytle, F. W.; Stern, E. A. Adv. X-ray Anal. 1970, 13, 248.

(361) Rehr, J. J. Radiat. Phys. Chem. 2006, 75, 1547.

(362) Sugiyama, S.; Moriga, T.; Hayashi, H.; Moffat, J. B. Bull. Chem. Soc. Jpn. 2001, 74, 187.

(363) Peters, F.; Schwarz, K.; Epple, M. Thermochim. Acta 2000, 361, 131.

(364) Korbas, M.; Rokita, E.; Meyer-Klaucke, W.; Ryczek, J. J. Biol. Inorg. Chem. 2004, 9, 67.

(365) James-Smith, J.; Cauzid, J.; Testemale, D.; Liu, W.; Hazemann, J. L.; Proux, O.; Etschmann, B.; Philippot, P.; Banks, D.; Williams, P.; Brugger, J. Am. Mineral. 2010, 95, 921.

(366) Bazin, D.; Rehr, J. J. J. Phys. Chem. B 2003, 107, 12398.

(367) Bazin, D.; Sayers, D.; Rehr, J. J.; Mottet, Ch. J. Phys. Chem. B 1997, 101, 5332.

(368) Bazin, D.; Guczi, L. Appl. Catal., A 2001, 213, 147.

(369) Liou, S. C.; Chen, S. Y.; Lee, H. Y.; Bow, J. S. Biomaterials 2004, 25, 189.

(370) Bazin, D.; Rehr, J. Catal. Lett. 2003, 87, 85.

(371) Benzarara, K.; Yoon, T. H.; Tyliszczapp, K. T.; Constantz, B.; Spormann, A. M.; Brown, G. E., Jr Geobiology 2004, 2, 249.

(372) Bazin, D.; Carpentier, X.; Traxer, O.; Jungers, P.; Reguer, S.; Thiaudière, D.; Daudon, M. J. Synchrotron Radiat. 2008, 15, 506.

(373) Bazin, D; Carpentier, X; Brocheriou, I; Dorfmuller, P.; Aubert, S.; Chappard, Ch.; Thiaudière, D.; Reguer, S.; Waychunas, G.; Jungers, P.; Daudon, M. Biochimie 2009, 91, 1294.

(374) Carpentier, X.; Bazin, D.; Jungers, P.; Reguer, S.; Thiaudière, D.; Daudon, M. J. Synchrotron Radiat. 2010, 17, 374.

(375) Eiden-Assmann, S.; Viertelhaus, M., Hasylab-Jahresbericht 1999; Hasylab/Desy: Hamburg, Germany, 2000.

(376) Asokan, K.; Jan, J. C.; Chiou, J. W. J. Synchrotron Radiat. 2001, $8,839$.

(377) Farges, F.; Brown, G. E.; Rehr, J. J. Phys. Rev. B 1997, 56, 1809.
(378) Brun, E.; Jugan, M.-L.; Herlin-Boime, N.; Jaillard, D.; Fayard, B.; Flank, A.-M.; Mabondzo, A.; Carrière, M. Int. J. Mod. Phys.: Conf. Ser. 2011, 304, 012048.

(379) Larue, C.; Veronesi, G.; Flank, A. M. ; Surblé, S.; HerlinBoime, N.; Carrière, M. J. Toxicol. Environ. Health, Part A 2012, 75, 1.

(380) Asokan, K.; Jan, J. C.; Chiou, J. W.; Pong, W. F.; Tseng, P. K.; Lin, I. N. J. Synchrotron Radiat. 2001, 8, 839.

(381) Kwiatek, W. M.; Hanson, A. L.; Paluszkiewicz, C.; Gałka, M.; Gajda, M.; Cichocki, T. J. Alloys Compd. 2004, 362, 83.

(382) Magalhães, T.; Becker, M.; Carvalho, M. L.; von Bohlen, A. Spectrochim. Acta, Part B 2008, 63, 1473.

(383) Podgorczyk, M.; Kwiatek, W. M.; Grolimund, D.; Borca, C. Radiat. Phys. Chem. 2009, 78, S53.

(384) Shilstein, S.Sh.; Cortesi, M.; Breskin, A.; Chechik, R.; Vartsky, D.; Raviv, G.; Kleinman, N.; Ramon, J.; Kogan, G.; Gladysh, V.; Moriel, E.; Huszar, M.; Volkov, A.; Fridman, E. Talanta 2006, 70, 914. (385) Orton, B. R.; Bilsborrow, R. J. Synchrotron Radiat. 2008, 15, 641.

(386) Provost, K.; Bouvet-Muller, D.; Crauste-Manciet, S.; Moscovici, J.; Olivi, L.; Vlaic, G.; Michalowicz, A. Biochimie 2009, 91, 1301.

(387) Provost, K.; Bouvet-Muller, D.; Crauste-Manciet, S.; Olivi, L.; Vlaic, G.; Michalowicz, A. J. Phys.: Conf. Ser. 2009, 190, 012206 DOI: $10.1088 / 1742-6596 / 190 / 1 / 012206$.

(388) Hall, M. D.; Alderden, R. A.; Zhang, M.; Beale, P. J.; Cai, Z. H.; Lai, B.; Stampfl, A. P. J.; Hambley, T. W. J. Struct. Biol. 2006, 155, 38. (389) Beret, E. C.; Provost, K.; Müller, D.; Marcos, E. S. J. Phys. Chem. B 2009, 113, 12343.

(390) Crossley, E. L.; Aitken, J. B.; Vogt, S.; Harris, H. H.; Rendina, L.M.. Aust. J. Chem. 2011, 64, 253.

(391) Benhamou, C. L. Joint Bone Spine 2007, 74, 39.

(392) Rochefort, G. Y.; Pallu, S.; Benhamou, C. L. Osteoporosis Int. 2010, 21, 1457.

(393) Roschger, P.; Manjubala, N.; Zoeger, N.; Meirer, F.; Simon, R.; Li, Ch.; Fratzl-Zelman, N.; Misof, B. M.; Paschalis, E. P.; Streli, Ch.; Fratzl, P.; Klaushofer, K. J. Bone Miner. Res. 2010, 25, 891.

(394) Farlay, D.; Boivin, G.; Panczer, G.; Lalande, A.; Meunier, P. J. J. Bone Miner. Res. 2005, 20, 1569.

(395) Verberckmoes, S. C.; Behets, G. J.; Oste, L.; Bervoets, A. R.; Lamberts, L. V.; Drakopoulos, M.; Somogyi, A.; Cool, P.; Dorrine, W.; De Broe, M. E.; D'Haese, P. C. Calcif. Tissue Int. 2004, 75, 405.

(396) Li, C.; Paris, O.; Siegel, S.; Roschger, P.; Paschalis, E. P.; Klaushofer, K.; Fratzl, P.; Cabrera, W. E.; Schrooten, I.; De Broe, M. E.; D́ Haese, P. C. J. Bone Miner. Res. 1999, 14, 661.

(397) Camacho, N. P.; Rinnerthaler, S.; Paschalis, E. P.; Mendelsohn, R.; Boskey, A. L.; Fratzl, P. Bone 1999, 25, 287.

(398) Cabrera, W. E.; Schrooten, I.; De Broe, M. E.; D́ Haese, P. C. J. Bone Miner. Res. 1999, 14, 661.

(399) O’Day, P. A.; Newville, M.; Neuhoff, P. S.; Sahai, N.; Carroll, S. A. J. Colloid Interface Sci. 2000, 222, 184.

(400) Persson, I.; Sandstrom, M.; Yokoyama, H.; Chaudry, M., Z. Naturforsch. A 1995, 50, 21.

(401) Terra, J.; Dourado, E. R.; Eon, J. G.; Ellis, D. E.; Gonzalez, G.; Malta Rossi, A. Phys. Chem. Chem. Phys. 2009, 11, 568.

(402) Rehr, J. J.; Ankudinov, A. L. J. Synchrotron Radiat. 2001, 8, 61. (403) Bazin, D.; Rehr, J. J. J. Phys. Chem. C 2011, 115, 23233.

(404) Sayers, D. A.; Lytle, F. W.; Stern, E. A. In Advances in X-ray Analysis; Henke, B. L., Newkirk, J. B., Mallett, G. R., Ed.; Plenum: New York; 1970; Vol 13, p 248.

(405) Moonen, J.; Slot, J.; Lefferts, L.; Bazin, D.; Dexpert, H. Phys. B 1995, 208, 689.

(406) Sayers, D. E.; Stern, E. A.; Lytle, F. W. Phys. Rev. Let 1971, 27, 1204.

(407) Ressler, T. J. Synchrotron Radiat. 1998, 5, 118.

(408) Arcovito, A.; Benfatto, M.; D'Angelo, P.; Della Longa, S. AIP Conf. Proc. XAFS 13 2007, No. CP882, 306.

(409) Pickering, I. J.; George, G. N. AIP Conf. Proc. XAFS 13 2007, No. CP882, 311. 
(410) Ascone, I.; Nobili, G.; Benfatto, M.; Congiu-Castellano. AIP Conf. Proc. XAFS 13 2007, No. CP882, 319.

(411) Murray Booth, A.; Braun, S.; Lonsbourough, T.; Purton, J.; Patel, S.; Schroder, S. L. M. AIP Conf. Proc. XAFS 13 2007, No. CP882, 325

(412) Ralle, M.; Blackburn, N. J.; Luesenko, S. AIP Conf. Proc. XAFS 13 2007, No. CP882, 328.

(413) Eanes, E. D.; Powers, L.; Cost, J. L. Cell Calcium 1981, 2, 251.

(414) Harries, J. E.; Hukins, D. W. L.; Hasnain, S. S. Calcif. Tissue Int. 1988, 43, 250.

(415) Jalilehvand, F.; Spangberg, D.; Lindqvist-Reis, P.; Hermansson, K.; Persson, I.; Sandstrom, M. J. Am. Chem. Soc 2001, 123, 431.

(416) Harries, E.; Hasnain, S. S.; Shah, J. S. Calcif. Tissue Int. 1987, $41,346$.

(417) Hukins, D. W. L.; Cox, A. J.; Harries, J. E. J. Phys. (Paris) 1986, C8, 1181.

(418) Holt, C.; Hukins, D. W. L. Int. Dairy J. 1991, 1, 151

(419) Philippot, P.; Menez, B.; Chevallier, P.; Gibert, F.; Legrand, F.; Populus, P. Chem. Geol. 1998, 144, 121.

(420) Wobrauschek, P.; Kregsamer, P.; Mantler, M. X-ray Fluorescence Analysis. In Instrumental Multi-Element Chemical Analysis; Kluwer: Dordrecht, Netherlands, 1998; pp 302-345.

(421) Ekinci, N.; Astamb, N.; Sahin, Y. J. Quant. Spectrosc. Radiat. Transfer 2002, 72, 783.

(422) Ekinci, N.; Sahin, Y. Spectrochim. Acta, Part B 2002, 57, 167.

(423) Ekinci, N.; Sahin, Y. J. Quant. Spectrosc. Radiat. Transfer 2004, 86, 379.

(424) Magalhães, T.; Becker, M.; Carvalho, M. L.; Von Bohlen, A. Spectrochim. Acta, Part B 2008, 63, 1473.

(425) Erko, A.; Agafonov, Yu.; Panchenko, L. A.; Yakshin, A.; Chevallier, P.; Dhez, P.; Legrand, P. Opt. Commun. 1994, 106, 146.

(426) Snigireva, I.; Snigirev, A. J. Envron. Monitor. 2006, 8, 33.

(427) Carmona, A.; Devs, G.; Roudeau, S.; Cloetens, P.; Bohic, S.; Ortega, R. ACS Chem. Neurosci 2010, 1, 94.

(428) Golovanova, O. A.; Belskaya, L. V.; Berezina, N. Yu. J. Appl. Spectrosc. 2006, 73, 886.

(429) Pal'chik, N. A.; Moroz, T. N.; Maksimova, N. V.; Darin, A. V. Russ. J. Inorg. Chem. 2006, 51, 1098.

(430) Pinheiro, T.; Carvalho, M. L.; Casaca, C.; Barreiros, M. A.; Cunha, A. S.; Chevallier, P. Nucl. Instrum. Methods Phys. Res., Sect. B 1999, 158, 393.

(431) Carvalho, M. L.; Casaca, C.; Pinheiro, T.; Marques, J. P.; Chevallier, P.; Cunha, A. S. Nucl. Instrum. Methods Phys. Res., Sect. B 2000, 168, 559 .

(432) Abraham, J. A.; Grenón, M. S.; Sánchez, H. J.; Valentinuzzi, M. C.; Perez, C. A. Spectrochim. Acta, Part B 2007, 62, 689.

(433) Zhang, Y. X.; Wang, Y. S.; Zhang, Y. P.; Zhang, G. L.; Huang, Y. Y.; He, W. Nucl. Instrum. Methods Phys. Res., Sect. B 2007, 260, 178.

(434) Fei, Y.; Zhang, Li, M; Huang, Y.; He, W.; Ding, Yang, J. Micron 2007, 38, 637.

(435) Carpentier, X.; Bazin, D.; Combes, Ch.; Mazouyes, A.; Rouzière, S.; Albouy, P. A.; Foy, E.; Daudon, M. J. Trace Elem. Med. Biol. 2011, 25, 160.

(436) Tsuji, K.; Nakano, K.; Hayashi, H.; Hayashi, K.; Ro, C. U. Xray Spectrom. Anal. Chem. 2008, 80, 4421.

(437) Szalki, I.; Osn, J.; Van Grieken, E. Anal. Chem. 2006, 78, 4069.

(438) Uda, M.; Maeda, K.; Sasa, Y. Nucl. Instrum. Methods Phys. Res., Sect. B 1987, 22, 184

(439) Naga Raju, G. J.; Charles, M. J.; Reddy, S. B. Nucl. Instrum. Methods Phys. Res., Sect. B 2005, 229, 457.

(440) Pougnet, M. A. B.; Peisach, M.; Rodgers, A. L. Nucl. Instrum. Methods Phys. Res., Sect. B 1988, 35, 472.

(441) Khodja, H.; Berthoumieux, E.; Daudin, L.; Gallien, J.-P. Nucl. Instrum. Methods Phys. Res., Sect. B 2001, 181, 83

(442) Daudin, L.; Khodja, H.; Gallien, J. P. Nucl. Instrum. Methods Phys. Res., Sect. B 2003, 210, 153.

(443) St-Pierre, J. P.; Pilliar, R. M.; Grynpas, M. D.; Kandel, R. A. Acta Biomater. 2010, 6, 3302.
(444) Lau, A. G.; Kindig, M. W.; Kent, R. W. Acta Biomater. 2011, 7, 1202

(445) Oka, T.; Yoshioka, T.; Koide, T.; Takaha, M.; Sonoda, T. Urol. Int. 1987, 42, 89.

(446) Touryan, L. A.; Lochhead, M. J.; Marquardt, B. J.; Vogel, V. Nat. Mater. 2004, 3, 239.

(447) Guo, C. H.; Chen, P. C.; Yeh, M. S.; Hsiung, D. Y.; Wang, C. L. Clin. Biochem. 2011, 44, 275.

(448) Liu, G.; Talley, J. W.; NA, C.; Larson, S.; Wolfe, L. Environ. Sci. Technol. 2010, 44, 1366.

(449) Bradley, D. A.; Kaabar, K.; Gundogdu, O.; Farquharson, M. J.; Janousch, M.; Bailey, M.; Jeynes, C. Nucl. Instrum. Methods Phys. Res., Sect. A 2010, 619, 330.

(450) Bradley, D. A.; Moger, C. J.; Winlove, C. P. Nucl. Instrum. Methods Phys. Res., Sect. A 2007, 580, 473.

(451) Meirer, F.; Pemmer, B.; Pepponi, G.; Zoeger, N.; Wobrauschek, P.; Sprio, S.; Tampieri, F.; Goettlicher, J.; Steininger, R.; Mangold, R.; Roschger, P.; Berzlanovich, A.; Hofstaettere, J. G.; Strelia, Ch. J. Synchrotron Radiat. 2011, 18, 238.

(452) Szaloki, I.; Lewis, D. G.; Bennettk, C. A.; Kilic, K. Phys. Med. Biol. 1999, 44, 1245.

(453) Benazeth, S.; Bazin, D.; Viosat, B.; Dexpert, H.; Laruelle, P.; N'guyen, G. J. Chim. Phys. 1989, 718, 1635.

(454) Takeda, T. Nucl. Instrum. Methods Phys. Res., Sect. A 2005, 548, 38.

(455) Zhang, Y.; Cheng, F.; Li, D.; Wang, Y.; Zhang, G.; Liao, W.; Tang, T.; Huang, Y.; He, W. Biol. Trace Elem. Res. 2005, 103, 177.

(456) Fayard, B.; Salomé, M.; Takemoto, K.; Kihara, H.; Susini, J. J. Electron Spectrosc. Relat. Phenom. 2009, 170, 19.

(457) Palmer, B. M.; Vogt, S.; Chen, Z.; Lachapelle, R. R.; LeWinter, M. M. J. Struct. Biol. 2006, 155, 12.

(458) Liu, N. Q.; Zhang, F.; Wang, X. F.; Zhang, Z. Y.; Chai, Z. F.; Huang, Y. Y.; He, W.; Zhao, X. Q.; Zuo, A. J.; Yang, R. Spectrochim. Acta, Part B 2004, 59, 255.

(459) Yoshida, S.; Ide-Ektessabi, A.; Fujisawa, S. Struct. Chem. 2003, $14,1$.

(460) Ide-Ektessabi, A.; Ota, Y.; Ishihara, R.; Mizuno, Y.; Takeuchi, T. Nucl. Instrum. Methods Phys. Res., Sect. B 2005, 241, 681.

(461) Muthuvelu, P.; Ellis, R. E.; Green, E. M.; Attenburrow, D.; Barrett, R.; Arkill, K.; Colridge, D. B.; Winlove, C. P.; Bradley, D. A. J. Radioanal. Nucl. Chem. 2007, 271, 771.

(462) Chwiej, J.; Fik-Mazgaj, K.; Szczerbowska-Boruchowska, M.; Lankosz, M.; Ostachowicz, J.; Adamek, D.; Simionovici, A.; Bohic, S. Anal. Chem. 2005, 77, 2895.

(463) Gerhardsson, L.; Borjesson, J.; Grubb, A.; Hultberg, B.; Mattsson, S.; Schutz, A.; Skerfving, S. Appl. Radiat. Isot. 1998, 49, 711. (464) O’Meara, J. M.; Börjesson, J.; Chettle, D. R.; McNeill, F. E. Nucl. Instrum. Methods Phys. Res., Sect. B 2004, 213, 560.

(465) Lee, S. H.; Gardner, R. P.; Todd, A. C. Appl. Radiat. Isot. 2001, 54, 893.

(466) Nie, H.; Chettle, D.; Luo, L.; O’Meara, J. Nucl. Instrum. Methods Phys. Res., Sect. B 2007, 263, 225.

(467) Luo, L.; Chettle, D. R.; Nie, H.; McNeill, F. E.; Popovic, M. Nucl. Instrum. Methods Phys. Res., Sect. B 2007, 263, 258.

(468) Nie, H.; Chettle, D.; Stronach, I.; Arnold, M.; Huang, S.; McNeill, F.; Meara, J. Nucl. Instrum. Methods Phys. Res., Sect. B 2004, 213, 579.

(469) Zaichick, V. Ye.; Ovchjarenko, N. N. J. Trace Microprobe Tech. 1996, 14, 143.

(470) Zaichick, V.; Ovchjarenko, N.; Zaichick, S. Appl. Radiat. Isot. 1999, 50, 283.

(471) Homma-Takeda, S.; Takenaka, Y.; Kumagai, Y.; Shimojo, N. Environ. Toxicol. Pharmacol. 1999, 7, 179.

(472) Ancharov, A. I.; A. I. Nizovskii, A. I.; Potapov, S. S.; Moiseenko, T. N.; Feofilov, I. V. Nucl. Instrum. Methods Phys. Res., Sect. A 2007, 575, 221.

(473) Ancharov, A. I.; Potapov, S. S.; Moiseenko, T. N.; Feofilov, I. V.; Nizovskii, A. I. Nucl. Instrum. Methods Phys. Res., Sect. A 2007, 575, 221. 
(474) Thomlinson, B. Synchrotron Radiat. News 2011, 24, 2.

(475) Suortti, P.; Thomlinson, W. Phys. Med. Biol. 2003, 48, R1.

(476) Elleaume, H.; Charvet, A. M.; Corde, S.; Estève, F.; Le Bas, J. F. Phys. Med. Biol. 2002, 47, 3369.

(477) Adam, J. F.; Joubert, A.; Biston, M. C.; Charvet, A. M.; Balosso, J.; Le Bas, J. F.; Estève, F.; Elleaume, H. Int. J. Radiat. Oncol. Biol. Phys. 2005, 61, 1173.

(478) Bertrand, B.; Estève, F.; Elleaume, H.; Nemoz, C.; Fiedler, S.; Bravin, A.; Berruyer, G.; Brochard, T.; Renier, M.; Machecourt, J.; Thomlinson, W.; Le Bas, J. F. Eur. Heart J. 2005, 26, 1284.

(479) Elleaume, H.; Fiedler, S.; Estève, F.; Bertrand, B.; Charvet, A. M.; Berkvens, P.; Berruyer, G.; Brochard, T.; Le Duc, G.; Nemoz, C.; Renier, M.; Suortti, P.; Thomlinson, W.; Le Bas, J. F. Phys. Med. Biol. 2000, 45, L39.

(480) Szabo De Edelenyi, F.; Rubin, C.; Estève, F.; Grand, S.; Décorps, M.; Lefournier, V.; Le Bas, J. F.; Remy, C. Nat. Med. 2000, 6, 1287

(481) Elleaume, H.; Charvet, A. M.; Corde, S.; Estève, F.; Le Bas, J. F. Phys. Med. Biol. 2002, 47, 3369.

(482) Corde, S.; Biston, M. C.; Elleaume, H.; Estève, F.; Charvet, A.; Joubert, A.; Ducros, V.; Bohic, S.; Simionovici, A.; Brochard, T.; Nemoz, C.; Renier, M.; Troprès, I.; Fiedler, S.; Bravin, A.; Thomlinson, W.; Le Bas, J. F.; Balosso, J. Radiat. Res. 2002, 158, 763.

(483) Salome, M.; Peyrin, F.; Cloetens, P.; Odet, C.; Laval-jeantet, A. M.; Baruchel, J.; Spanne, P. Med. Phys. 1999, 26, 2194.

(484) Peyrin, F.; Mastrogiacomo, M.; Cancedda, R.; Martinetti, R. Biotechnol. Bioeng. 2007, 97, 638.

(485) Nuzzo, S.; Peyrin, F.; Cloetens, P.; Baruchel, J.; Boivin, G. Med. Phys. 2002, 19, 2672.

(486) Bousson, V.; Peyrin, F.; Bergot, C.; Hausard, M.; Sautet, A.; Laredo, J. D. J. Bone Miner. Res. 2009, 19, 794.

(487) Peyrin, F. Osteoporosis Int. 2011, 22, 2043.

(488) Peyrin, F.; Salome, M.; Nuzzo, S.; Cloetens, P.; Laval-Jeantet, A. M.; Baruchel, J. Cell. Mol. Biol. 2000, 46, 1089.

(489) Nuzzo, S.; Lafage-Proust, M. H.; Martin-Badosa, E.; Boivin, G.; Thomas, T.; Alexandre, C.; Peyrin, F. J. Bone Miner. Res.. 2002, 17, 1372

(490) Dreossi, D.; Abrami, A.; Arfelli, F.; Bregant, P.; Casarin, K.; Chenda, V.; Cova, R.; Longo, M. A.; Menk, R.-H.; Quai, E.; Quaia, E.; Rigon, L.; Rokvic, T.; Sanabor, D.; Tonutti, M.; Tromba, G.; Vascotto, A.; Zanconati, F.; Castelli, E. Eur. J. Radiol. 2008, 68, S58.

(491) Castelli, E.; Arfelli, F.; Dreossi, D.; Longo, F.; Rokvic, T.; Cova, M. A.; Quaia, E.; Tonutti, M.; Zanconati, F.; Abrami, A.; Chenda, V.; Menk, R. H.; Quai, E.; Tromba, G.; Bregant, M.; de Guarrini, F. Nucl. Instrum. Methods Phys. Res., Sect. A 2007, 572, 237.

(492) Zarse, C. A.; McAteer, J. A.; Sommer, A. J.; Kim, S. C.; Hatt, E. K.; Lingeman, J. E.; Evan, A. P.; Williams, J .C., Jr BMC Urol. 2004, 4, 15.

(493) Biskupek, J.; Leschner, J.; Walther, P.; Kaiser, U. Ultramicroscopy 2010, 110, 1231.

(494) Pereira, G. R.; Rocha, H. S.; Calza, C.; Anjos, M. J.; Lima, L.; Pérez, C. A.; Lopes, R. T. Nucl. Instrum. Methods Phys. Res., Sect. A 2011, 652, 684.

(495) http://www.synchrotron-soleil.fr/Soleil/ToutesActualites/ 2010/Du-synchrotron-a-l-hopital (accessed January 2010).

(496) Takeda, T.; Itai, Y.; Hyodo, K.; Ando, M.; Akatsuka, T.; Uyama, C. J. Synchrotron Radiat. 1998, 5, 326.

(497) Bohic, S.; Cotte, M.; Salomé, M.; Fayard, B.; Kuehbacher, M.; Cloetens, P.; Martinez-Criado, G.; Tucoulou, R.; Susini, J. J. Struct. Biol. 2012, 177, 248.

(498) Pelka, J. B. Radiat. Phys. Chem. 2009, 78, S142.

(499) Margaritondo, G.; Hwu, Y.; Je, J. H. Riv. Nuovo Cimento Soc. Ital. Fis. 2004, 27, 1.

(500) Lewis, R. A. Nucl. Instrum. Methods Phys. Res., Sect. A 2005, $548,23$.

(501) Bravin, A.; Noguera, R.; Sabes, M.; Sobreques, J. ALBA Biomedical Beamline (ABME). A Proposal for the ALBA S.A.C.Barcelona; S.A.C.: Barcelona, 2004.
(502) Charvet, A. M. ; Lartizien, C. ; Esteve, F. ; Le Duc, G. ; Collomb, A.; Elleaume, H. ; Fiedler, S. ; Thompson, A. ; Brochard, T.; Kleuker, U. ; Stetner, H. ; Spanne, P. ; Suortti, P. ; Le Bas, J. F. In Medical Applications of Synchrotron Radiation; Ando, M., Uyama, C., Eds.; Springer: Berlin, 1997.

(503) Ando, M.; Hyodo, K.; Nishimura, K.; Ohtsuka, S.; Takeda, T.; Sugishita, Y.; Itai, Y. The Medical Application Programme Using AR \& PF ring at KEK Phys. Med. XIII; Elsevier: London, 1997; pp1-6.

(504) Sun, Z. Australasian Med. J. 2009, 1, 1.

(505) Torikoshi, M.; Endo, M.; Kumada, M.; Noda, K.; Yamada, S.; Kawachi, K. Part. Accel. Conf., 1997. Proc. 1997, 1, 820.

(506) Hasnain, S. S. J. Synchrotron Radiat. 2007, 14, 297.

\section{NOTE ADDED AFTER ASAP PUBLICATION}

This paper was published on the Web on July 19, 2012, with some corrections throughout the paper not made. The corrected version was reposted on July 25, 2012. 